
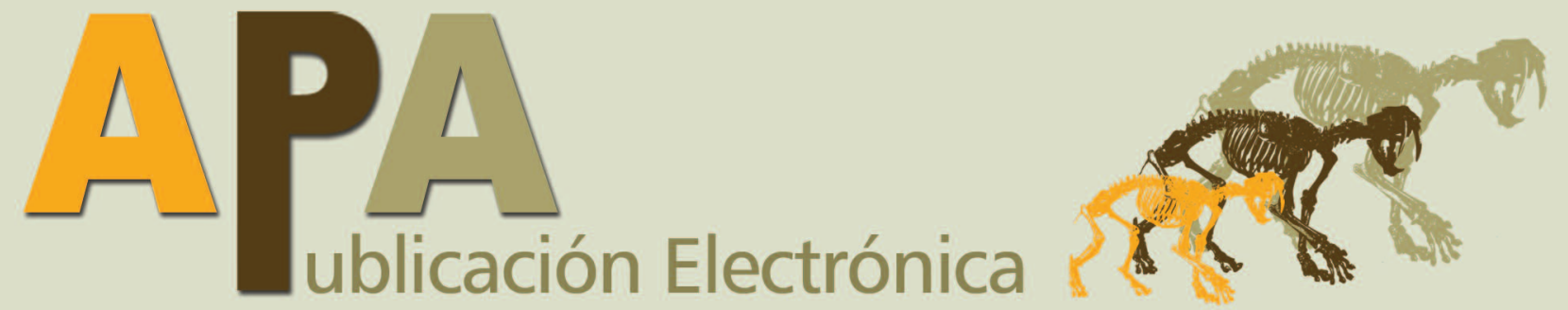

\title{
XXXII JORNADAS ARGENTINAS DE PALEONTOLOGÍA DE VERTEBRADOS
}

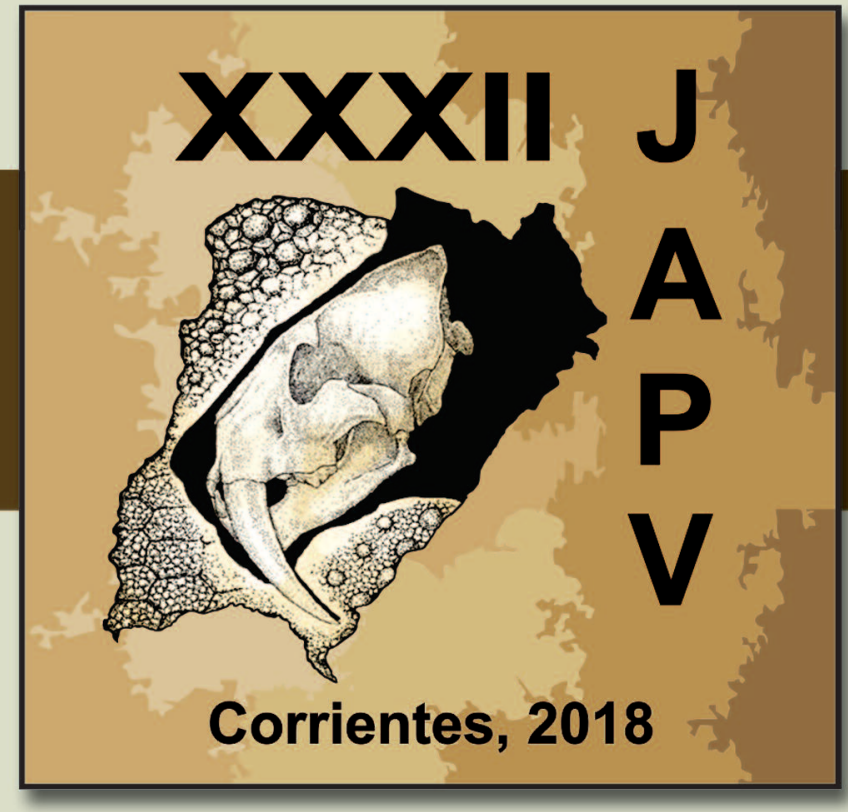

\author{
VII JORNADAS TÉCNICAS \\ DE PALEONTOLOGİA DE VERTEBRADOS
}

LIBRO DE RESÚMENES

14 al 17 de mayo de 2018 


\section{JORNADAS ARGENTINAS DE PALEONTOLOGÍA DE VERTEBRADOS \\ VII JORNADAS TÉCNICAS DE PALEONTOLOGÍA DE VERTEBRADOS}

14 AL 17 DE MAYO DE 2018, CORRIENTES, ARGENTINA

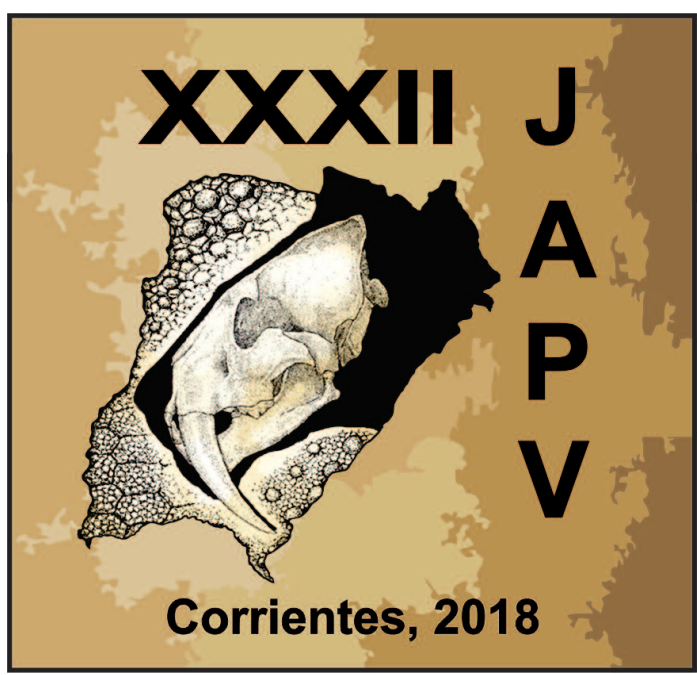

LIBRO DE RESÚMENES

\section{Auspician}

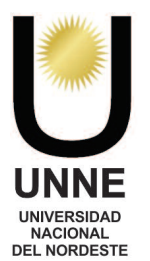

Facultad de Ciencias Exactas y Naturales y Agrimensura
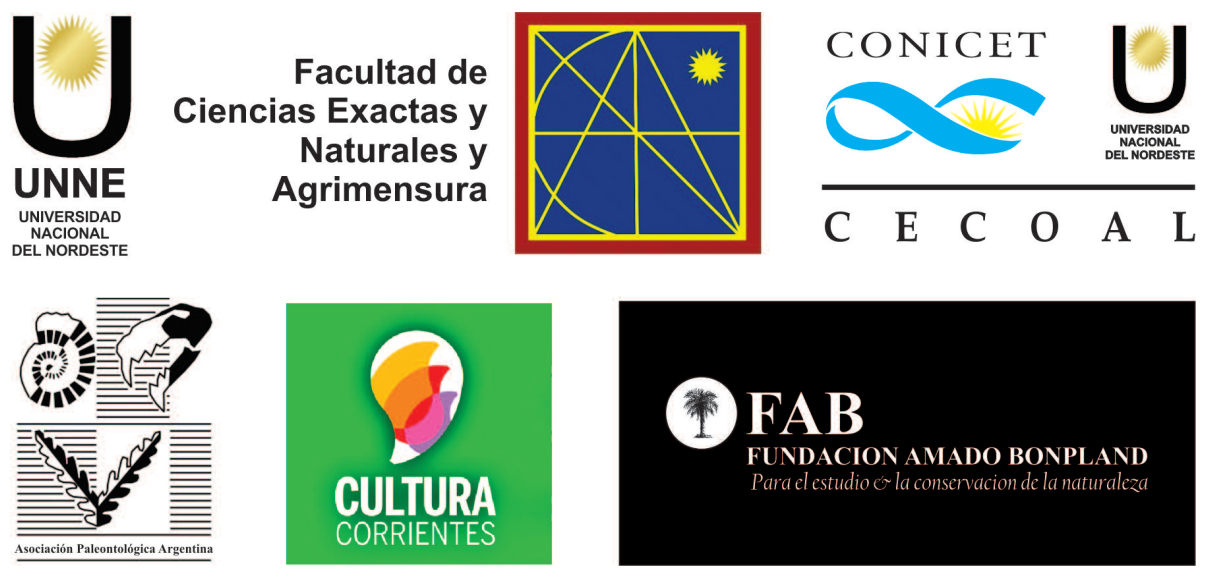

\section{1) FAB}




\title{
COMISIÓN ORGANIZADORA
}

\author{
Alfredo E. Zurita \\ Ángel R. Miño-Boilini \\ Carlos A. Luna \\ Francisco Cuadrelli \\ Cecilia Méndez \\ Romina González \\ Sofía Quiñones \\ Silvina Contreras \\ Pedro Cuaranta \\ María Florencia Romero-Marain \\ María Luz Irrázabal \\ Luciano Rey
}

\section{REVISORES CIENTÍFICOS}
Sebastián Apesteguía
Leonardo Avilla
Beatriz Azanza
Mattia Baiano
Fernando Barbosa
Benjamín Bender
Paula Bona
Diego Brandoni
Juan Ignacio Canale
Adriana Candela
José Luis Carballido
Ignacio Cerda
Laura Cruz
Silvina De valais
Julia Desojo
Georgina Erra
Graciela Esteban
Martin Ezcurra
Leonardo Filippi
Pablo Gallina
Germán Gasparini
Federico Gianechini
Guillermina Giordano
Raúl Gómez
Laureano M. González
Martin Hechenleitner
María Luz Irrazábal

Marcelo Isasi

Jonatan Kaluza

Emil Krupandan

Rocío García Mancuso

Ignacio Díaz Martínez

Agustín Martinelli

Dimila Mothé

Matias Motta

Norma Nasif

José O'Gorman

Daniel Perea

María E. Pérez

Juan Porfiri

María Cecilia Prieto

Santiago Reuil

Facundo Riguetti

Sergio Rodríguez

Alejo Scarano

Torsten Scheyer

Esteban Soibelzon

Leopoldo Soibelzon

Juliana Sterli

Jeremías Taborda

Martín Ubilla

Carolina Vieytes

Martín Zamorano

Virginia Zurriaguz 
PE-APA 19 (1) - Suplemento RESÚMENES

\title{
CONFERENCIAS
}

\section{GRUPO CONSERVACIONISTA DE SAN PEDRO. UNA HISTORIA DE PASIÓN POR EL RESGUARDO DEL PATRIMONIO CULTURAL}

\begin{abstract}
J.L. Aguilar ${ }^{1}$
${ }^{1}$ Grupo Conservacionista de San Pedro, Museo Paleontológico "Fray Manuel de Torres", Carlos Pellegrini 145, 2930 San Pedro, Buenos Aires, Argentina.gcfosiles@gmail.com

El Grupo Conservacionista de San Pedro es un equipo conformado por vecinos de dicha localidad bonaerense, autodidactas, comprometidos en la búsqueda, preservación y difusión de diferentes aspectos del patrimonio cultural de su zona. Nacido en 1998 por el hallazgo casual de un fósil, lograron destacarse por idear un verdadero circuito temático en su localidad que incluye temas como la paleontología, historia naval, arquitectura histórica, biología, historia argentina, historia agropecuaria y preservación documental. La experiencia capitalizada por sus integrantes contribuyó al desarrollo de diez lugares vinculados a la difusión y conocimiento del patrimonio cultural de San Pedro y zona. La creación de museos, salas temáticas, valoración de espacios históricos y recuperación documental fueron desarrollos abordados por el grupo fundador del Museo Paleontológico "Fray Manuel de Torres". El rescate de unas 50 especies de interés paleontológico, la publicación y digitalización de centenares de documentos históricos, la recuperación de decenas de objetos del combate de la Vuelta de Obligado, la formación de una colección de numerosos objetos rurales históricos, la puesta en valor de vestigios del convento fundacional de San Pedro y la restauración, diseño de contenido y distribución del museo naval "Buque Comandante Gral. Irigoyen", fueron algunos de los desafíos aceptados por el Grupo Conservacionista a lo largo de sus 20 años de trayectoria. Desde 2003, son fundadores, administradores, difusores y equipo activo del Museo Paleontológico de San Pedro, base de operaciones fundamental para la concreción de los desarrollos mencionados.
\end{abstract}

\section{DINOSAURIOS EN EL LITORAL ARGENTINO-URUGUAYO: ENTRE LA PATAGONIA Y BRASIL}

\section{S. Apesteguía 1,2}

${ }^{1}$ Consejo Nacional de Investigaciones Científicas y Técnicas (CONICET).

2Área de Paleontología, Fundación de Historia Natural Félix de Azara, Centro de Estudios Biomédicos, Biotecnológicos, Ambientales y Diagnóstico (CEBBAD)-Universidad Maimónides. Hidalgo 775, C1405CBK Ciudad Autónoma de Buenos Aires, Argentina. sebapesteguia@gmail.com

La comparación de las faunas de dinosaurios del Triángulo Minero (SE de Brasil) con las de la cuenca Norte-Grupo Paysandú (oeste de Uruguay y litoral argentino) y los de la cuenca Neuquina (Patagonia argentina), permiten discutir relaciones de edad y de distribución faunística entre las tres cuencas. Aunque varios grupos de vertebrados terrestres han sido utilizados como herramienta fundamental en la comparación entre diferentes cuencas cretácicas sudamericanas, la relación existente entre Patagonia y Brasil es aún problemática y los intentos de solapamiento de especies no han sido del todo fructíferos. La existencia y estudio de rocas fosilíferas en regiones intermedias, como la cuenca de Paysandú, está proporcionando datos para ayudar en la interpretación. Los dientes de Carcharodontosauridae post-Coniacianos de Brasil y los espinosaurios de Argentina son cuestionados. Se evalúan los huevos de dinosaurio, huesos de deinonicosaurios, neovenatóridos, anquilosaurios, hadrosáuridos y saurópodos, particularmente de aeolosaurinos, presentes en las formaciones Allen y Marília. Aeolosaurus maximus Santucci y de Arruda Campos, 2011 de la Formación Adamantina, en Brasil y terópodos abelisáuridos braquirostros sugieren una conexión a comienzos del Cretácico Superior. Los taxones de Paysandú y Baurú son incompatibles con los términos inferiores del Grupo Neuquén, donde abundan carcarodontosáuridos y rebaquisáuridos. La similitud se da entre las formaciones Adamantina y Marília, en Brasil, y Bajo de la Carpa, Los Alamitos y Allen, en Argentina. Las barreras biogeográficas, aunque existentes para el Cretácico Inferior, parecen haberse suavizado para el Cretácico Superior pre-Maastrichtiano. 


\title{
EL PALEOARTE ARGENTINO. CARACTERÍSTICAS, VICISITUDES Y PERSPECTIVAS A FUTURO DE LA DISCIPLINA EN NUESTRO PAÍS
}

\author{
H.S. DRUETTA ${ }^{1}$
}

${ }^{1}$ Centro de Investigaciones en Ciencias de la Tierra (CICTERRA)-Consejo Nacional de Investigaciones Científicas y Tecnológicas (CONICET), Universidad Nacional de Córdoba. Av. Vélez Sarsfield 1611, X5016GCA Córdoba, Argentina. druettasantiago@gmail.com

El Paleoarte es una actividad artística que recrea a través de imágenes y esculturas los seres que vivieron en el pasado. Estas representaciones se encuentran delimitadas por el Arte, la Paleontología y el público, conjugando aspectos científicos y culturales de cada época. En la Argentina esta labor se desarrolla de manera independiente desde la década de 1980, adquiriendo en la actualidad singularidad propia. Para indagar en las características actuales se encuestó a los paleoartistas con el fin de obtener información precisa sobre la tarea. Entre los datos obtenidos se puede destacar: que la formación específica fue adquirida, en su mayoría, de manera autodidacta por parte de los artistas; que los espacios de exhibición son, generalmente, los museos de ciencias naturales y los eventos científicos y que la aceptación de los trabajos por los paleontólogos valoriza el carácter de las obras. Plásticamente, las técnicas utilizadas son tanto tradicionales como digitales, destacándose entre ellas el dibujo y la escultura. Por otro lado, la reconstrucción en vida de los organismos y sus ambientes es el tema más abordado por los paleoartistas argentinos. El Paleoarte es una disciplina en pleno crecimiento y necesita debates sobre problemáticas específicas como por ejemplo: el derecho de autor, el plagio, los costos de las obras y su formalización académica. El posicionamiento de los paleoartistas sobre estos y otros temas, sumado al apoyo de la Paleontología local en su promoción, contribuirá a que la actividad se encuentre fortalecida como comunidad artística frente a los cambios socioeconómicos que puedan devenir.

\section{APORTES DE LA TAFONOMÍA A LA INTERPRETACIÓN DE LAS ASOCIACIONES DE VERTEBRADOS CONTINENTALES DEL CENOZOICO SUPERIOR DEL CENTRO DE ARGENTINA}

\section{C.I. Montalvo ${ }^{1 *}$}

${ }^{1}$ Facultad de Ciencias Exactas y Naturales, Universidad Nacional de La Pampa. Av. Uruguay 151, L6300CLB Santa Rosa, La Pampa, Argentina. cmontalvo@exactas.unlpam.edu.ar

En los últimos años varias asociaciones faunísticas de vertebrados del Mioceno Tardío-Holoceno del centro de Argentina fueron objeto de evaluaciones tafonómicas. Se interpretó el origen de los yacimientos fósiles, vinculándolos con procesos físicos y/o biológicos, y en cada caso, se analizó detalladamente el contexto sedimentario de los niveles portadores. Además, se realizaron estudios actualísticos que permitieron comprender mejor los procesos involucrados en la formación de las asociaciones. Aquellas originadas por procesos físicos se registraron en sedimentos correspondientes a planicies de inundación y canales fluviales (Formación Arroyo Chasicó, Buenos Aires, Mioceno Tardío; Formación Cerro Azul, Cerro La Bota, La Pampa, Mioceno Tardío; Formación Monte Hermoso, Buenos Aires, Plioceno Temprano). Otras, pudieron ser vinculadas al desarrollo de suelos en el área portadora (Formación Cerro Azul, Telén, La Pampa, Mioceno Tardío). Las concentraciones de fósiles producidas por actividad biológica incluyen restos acumulados por acción depredadora de aves rapaces y mamíferos carnívoros. Así, se identificaron acumulaciones con restos de microvertebrados en coprolitos (Formación Monte Hermoso) y egagrópilas (Quequén Salado, Buenos Aires, Pleistoceno; Quehué, La Pampa, Holoceno). También se interpretaron depósitos que incluían restos no digeridos, descartados por los depredadores (Formación Cerro Azul, Estancia Ré, Caleufú y Telén, La Pampa, Mioceno Tardío). Otras asociaciones de microvertebrados se recuperaron del interior de paleocuevas (Quehué, La Pampa, Holoceno; Quequén Salado, Buenos Aires, Holoceno). En los casos estudiados fue posible describir los procesos que afectaron a los restos antes y después del enterramiento, definiendo así la historia tafonómica de cada asociación, y acotar temporalmente su lapso de formación.

*Proyecto 06G subsidiado por Facultad de Ciencias Exactas y Naturales, Universidad Nacional de La Pampa. 


\title{
PALEONEUROLOGÍA DE REPTILES DE LA ARGENTINA Y OTRAS PARTES DEL MUNDO: NUEVOS HALLAZGOS, NUEVOS INTERROGANTES Y NUEVAS PERSPECTIVAS
}

\author{
A. Paulina-Carabajal ${ }^{1}$ \\ ${ }^{1}$ Instituto de Investigaciones en Biodiversidad y Medioambiente (INIBIOMA)-Consejo Nacional de Investigaciones Científicas y Técnicas \\ (CONICET)-Universidad Nacional del Comahue. Quintral 1250, R8400FRF San Carlos de Bariloche, Río Negro, Argentina. \\ a.paulinacarabajal@conicet.gov.ar
}

La paleoneurología de dinosaurios es una de las ramas de la paleontología que más se ha visto beneficiada por el uso de tecnologías no invasivas, reflejando un aumento en el número de estudios durante los últimos 15 años. Estos estudios aportaron en primer lugar una cantidad significativa de información anatómica totalmente novedosa, concerniendo la morfología del cerebro y el oído interno de numerosas especies y generando un set de datos con potencial uso tanto en taxonomía, filogenia y paleobiología. El estudio de los sentidos - vista, olfato y circulación del aire en la cavidad nasal, audición, equilibrio y otros aspectos como termoregulación- acaparan la atención de paleontólogos desde que se descubrieron los primeros dinosaurios. El estudio reciente de las cavidades endocraneanas de taxones basales del Triásico como Saturnalia tupiniquim y Zupaysaurus rougieri está permitiendo -al menos en forma preliminar- determinar por primera vez el patrón evolutivo del sistema nervioso central en Sauropodomorpha y Theropoda a lo largo del Mesozoico. La presente charla intentará mostrar el estado actual del conocimiento de esta disciplina, recorriendo una breve historia de la paleoneurología de los dinosaurios e intentando responder a los siguientes interrogantes: Cómo los paleontólogos infieren tejidos blandos no preservados y realizan su reconstrucción. Qué es un correlato óseo. Métodos modernos en paleoneurología, y qué sabemos actualmente sobre la biología sensorial de los dinosaurios.

\section{AVE AVIS: NUEVAS MIRADAS Y CONCESIONES PARA EL ESTUDIO DE AVES FÓSILES}

\author{
C.P. TAMBUSSI ${ }^{1}$
}

${ }^{1}$ Centro de Investigaciones en Ciencias de la Tierra (CICTERRA)-Consejo Nacional de Investigaciones Científicas y Tecnológicas (CONICET), Universidad Nacional de Córdoba. Av. Vélez Sarsfield 1611, X5016GCA Córdoba, Argentina. tambussi@gmail.com

El legado de conocimientos de la paleontología clásica, aún vigente, no constituye solamente un bloque de conocimientos, teorías y lenguajes, sino por sobre todo un modo de razonamiento. Adicionalmente, la aplicación de nuevas técnicas y abordajes (modelización ecológica, morfometría geométrica, biomecánica, paleofisiología, paleogenética, paleohistología, paleoneurología, reconstrucción de tejidos blandos, trayectorias de desarrollo, etc.) ofrecen un nuevo marco para la asignación de nichos o de formas de vida -más paleobiológico- al registro fósil. De esta manera, la paleornitología está siendo nutrida con un aumento geométrico en la cantidad de datos e información. Inmersos en la era de la "big data" como la llamaron Jamie Wood y Vanesa De Pietri, corremos el riesgo de desatender los interrogantes a cuyo alrededor debe centrarse la investigación científica. Dos consecuencias, por lo menos, podrían extraerse de lo antedicho. La información que surge de la práctica clásica de la paleontología complementada con aquella obtenida a partir de nuevas fuentes de información, nos permite afrontar un proceso de reconstrucción que se recupera y enriquece con la crítica externa y lo reintegra mejorado. La novedad metodológica per se, no da respuestas a todas o a cualquier interrogante, esto es, se debe tener presente qué se puede y qué no contestar con el método que aplicamos. En los estudios contemporáneos sobre aves fósiles deben confluir estas dos vertientes. 


\title{
CONTRIBUCIONES CIENTÍFICAS
}

\section{PRIMER HALLAZGO DE UROLITOS EN UN EJEMPLAR DE FELIDAE (PLACENTALIA, CARNIVORA) PROCEDENTE DE MERCEDES, PROVINCIA DE BUENOS AIRES}

\author{
G.E. Acuña SuAREZ ${ }^{1,2}$ y S.L. LANZELOTTI ${ }^{1,3 *}$ \\ ${ }^{1}$ Equipo de Investigación Arqueológica y Paleontológica de la cuenca media y del río Luján (EiAP); Grupo de Estudios sobre SIG en Arqueolo- \\ gía, Paleontología e Historia (SIGAPH), Universidad Nacional de Luján. Ruta Nacional 5 y Avenida Constitución, B6702 Luján, Buenos Aires, \\ Argentina. \\ ${ }^{2}$ Facultad de Filosofía, Ciencias de la Educación y Humanidades, Universidad de Morón. Cabildo 134, B1708JPD Morón, Buenos Aires. \\ gabriel.acu@gmail.com \\ ${ }^{3}$ Instituto de las Culturas (IDECU)-Consejo Nacional de Investigaciones Científicas y Tecnológicas (CONICET)-Universidad de Buenos Aires. \\ Moreno 350, C1091AAH Ciudad Autónoma de Buenos Aires, Argentina.sonia.lanzelotti@conicet.gov.ar
}

Se presenta el primer hallazgo de urolitos o cálculos identificados en un ejemplar adulto de Smilodon populator. Dicho hallazgo corresponde a un espécimen recuperado sobre la margen izquierda del río Luján en las afueras de la localidad de Mercedes, provincia de Buenos Aires, en sedimentos asignados al Pleistoceno Tardío. La excavación y el análisis posterior de los restos estuvieron a cargo del Equipo de Investigación Arqueológica y Paleontológica de la cuenca media y superior del río Luján. Se recuperó el 90\% del total del esqueleto, el cual se presentaba articulado. Al interior de la cavidad pélvica se recuperaron urolitos sobre los cuales se realizaron análisis morfológicos y fisicoquímicos. Los resultados indican que los mismos estaban formados por cristales de carbonato de calcio y fosfato amónico magnésico (estruvita). Se propone a partir de la cantidad, tamaño y ubicación de los cálculos que los mismos habrían provocado una obstrucción de la uretra que habría desencadenado un fallo renal, causando posiblemente la muerte del espécimen. Se destaca que se trata no solo del primer registro de cálculos para esta especie, sino también para la megafauna en general.

*Proyecto "Paleoecología y poblamiento temprano en la cuenca superior y media del río Luján"

\section{DICRAEOSAURID SPINES. RESERVOIR HUMPS, THERMOREGULATORY SAILS, EXCESSIVE DISPLAYS OR MULTIPLE DEFENSIVE HORN-SPINES?}

\author{
Apesteguía ${ }^{1,2}$, P.A. Gallina ${ }^{1,2}$, and F. Riguetti ${ }^{1,2}$ \\ ${ }^{1}$ Consejo Nacional de Investigaciones Científicas y Técnicas (CONICET). \\ 2Área de Paleontología, Fundación de Historia Natural Félix de Azara, Centro de Estudios Biomédicos, Biotecnológicos, Ambientales y Diag- \\ nóstico (CEBBAD)-Universidad Maimónides. Hidalgo 775, C1405CBK Ciudad Autónoma de Buenos Aires, Argentina. sebapesteguia@gmail.com; \\ pablo.gallina@fundacionazara.org.ar; facu.riguetti@gmail.com
}

Since its finding in 1983, Amargasaurus cazaui Salgado and Bonaparte, 1991 was an interpretative headache. Although the long and acute neural spines were mainly considered as defensive, the preparation of the specimen revealed the easy breakage of these structures, despite the compositional change implied by fossilization. A recent publication correlated the $2 / 3$ of the distal spine with striated surface as keratinized sheath-covered structures. Though bone is stronger and stiffer in passive situations depending of strain and load, horns and other keratin-based materials are tougher and highly resistant to impact-caused fractures in dry to mesic conditions. Thus the cover sheath may transfer the load to the bony core along a radial direction. Additionally, is improved in slightly bent horns, and in sheaths much longer (double, as in some artiodactyls) than neural spines, thus reducing impulsive loads more than other geometries. In extant sauropsids, sheaths exceed less than $100 \%$ bony core length. However, keratinous sheath in other dinosaurs (i.e., in ankylosaurs) exceed up to $25 \%$ the bony core length. Under a defensive approach, the vast group of acute spines would represent a disturbing fence 
for a loitering carnivore, but under moderate charge, the breakage would affect only spine tips, not reaching the bone core of them. The acquiring of a defensive or display strategy based only in neural spine resistance is incompatible with their 10 My persistence, unless the lineage had an unknown spine resistance or a superb immunological system. A keratinous sheath is the more compatible of analyzed strategies.

\title{
REVISITING THEROPOD MATERIAL FROM THE LATE CRETACEOUS NESTING SITE AUCA MAHUEVO AND THE POSSIBLE RECORD OF A GIANT MEGARAPTORAN
}

\author{
M.A. BAIANO ${ }^{1,2}$, AND R.A. CORIA 1,3 \\ ${ }^{1}$ Museo Carmen Funes. Av. Córdoba 55, Q8318EBA Plaza Huincul, Neuquén, Argentina. \\ 2Instituto de Investigación en Paleobiología y Geología (IIPG)-Consejo Nacional de Investigaciones Científicas y Tecnológicas (CONICET), \\ Universidad Nacional de Río Negro. Av. Roca 1242, R8332EXZ Gral. Roca, Río Negro, Argentina. \\ ${ }^{3}$ Consejo Nacional de Investigaciones Científicas y Tecnológicas (CONICET).
}

The Megaraptora is an intriguing taxon of medium-sized theropod dinosaurs with disputed phylogenetic relationships. Depending on the chosen characters to be scored, megaraptorans can be understood either as the sister group of Carcharodontosauridae, or the sibling taxon of Tyrannosauroidea. Despite this unresolved phylogenetic scenario, the number of taxa attributed to Megaraptora is steadily increasing worldwide, especially in South America. In 2004, when analysing theropod material from the Auca Mahuevo sauropod nesting site, Coria and Arcucci reported the presence of indeterminate theropod material unrelated with the abelisaurid Aucasaurus garridoi Coria, Chiappe and Dingus, 2002, which it still is the only theropod species recognized from that site. The isolated, non-associated elements are represented by: MCF-PVPH418, an anterior dorsal centrum that is $110 \mathrm{~mm}$ long with a very narrowed mid-part of $82 \mathrm{~mm}$ wide, with deep, oval, lateral pleurocoels lacking any septum; MCF-PVPH-399, a robust, highly pneumatic distal half of a metatarsal II with deep lateral ginglymoids (both specimens from the Bajo de la Carpa Formation); and MCF-PVPH-416, a fragmentary pubic boot with unfused proximal symphysial contact, from the Anacleto Formation. This combination of features is present, although not exclusively, in virtually all megaraptoran taxa. Thus, in light of current knowledge, it would be possible to fine-tune the identification of these elements as Megaraptora indet., expanding their record up to the Campanian (based on specimen MCF-PVPH-416), and considering MCF-PVPH-418 likely the biggest megaraptoran bone so far collected.

\section{REVISIÓN DE LOS HIPOPÓTAMOS DEL MIOCENO SUPERIOR DE VENTA DEL MORO, PROVINCIA DE VALENCIA, ESPAÑA}

\author{
D. Barasoain ${ }^{1}$, P. MONTOYA ${ }^{2}$ Y J. MORales 3
}

${ }^{1}$ Centro de Ecología Aplicada del Litoral (CECOAL)-Consejo Nacional de Investigaciones Científicas y Tecnológicas (CONICET) y Universidad Nacional del Nordeste. Ruta 5, km 2,5, 3400 Corrientes, Argentina.danielbarasoain@gmail.com

2Departamento de Geología, Área de Paleontología, Universitat de València. Doctor Moliner 50, 46100 Burjassot, España. Plinio.Montoya@uv.es ${ }^{3}$ Museo Nacional de Ciencias Naturales (CSIC). José Gutiérrez Abascal 2, 28006 Madrid, España. jorge.morales@mncn.csic.es

El registro de hipopótamos miocenos es escaso y fragmentario en Europa, generando una larga problemática en cuanto a su clasificación taxonómica y posición filogenética. Especímenes procedentes del Mioceno superior de España e Italia se encuentran incluidos en Hexaprotodon Falconer y Cautley. El hallazgo de una mandíbula en La Portera mostró una relación con las formas africanas de edad similar, y se argumentó que la similitud en talla y morfología de los dientes de las especies reconocidas, procedentes de localidades incluidas en la MN13 del Mioceno superior, cercanas tanto geográfica como estratigráficamente, sugiere la presencia de una sola especie. Posteriormente se mostró la parafilia de Hexaprotodon, restringiendo el género a formas principalmente asiáticas, mientras que para la mayoría de formas africanas se propuso el género Archaeopotamus Boisserie. El principal objetivo de esta contribución es realizar una revisión de los materiales (colección MGUV, siglas VV 472-17696) del yacimiento español de Venta del Moro (provincia de Valencia), datado en 6.23 Ma, tradicionalmente asignados a Hexaprotodon. Las características observadas en los fósiles de Venta del Moro y La Portera descartan su inclusión dentro del género Hexaprotodon, mostrando sin embargo una mayor afinidad con Archaeopotamus sobre la base de la siguiente combinación de caracteres: 1) proceso alveolar de los incisivos fuertemente proyectado hacia el frente, 2) sínfisis mandibular estrecha y alargada, y 3) una similar longitud entre la línea de molares y premolares. Un futuro estudio detallado del conjunto del material español permitirá arrojar más luz sobre la evolución de este complejo grupo. 


\title{
PRELIMINARY DESCRIPTION OF A NEW SAUROPOD DINOSAUR FROM THE HUINCUL FOR- MATION (CENOMANIAN), AT NEUQUÉN PROVINCE, PATAGONIA, ARGENTINA
}

\author{
F. BELLARDINI' ${ }^{1}$, AND L.S. FILIPPI ${ }^{2}$
}

\begin{abstract}
`Dirección Provincial de Patrimonio Cultural, Departamento de Paleontología. Vuelta De Obligado 50, Q8300GYN Neuquén, Argentina. flaviobellardini@gmail.com

2Museo Municipal "Argentino Urquiza". Jujuy y Chaco s/n, Q8319BFA Rincón de los Sauces, Neuquén, Argentina. Isfilippi@gmail.com
\end{abstract}

At the end of 2017, a new partially articulated skeleton of a sauropod dinosaur was found in deposits of the Upper Cretaceous in the northwest of the Neuquén basin. The materials come from a thick sequence of sandstones corresponding to the Huincul Formation in the 'El Orejano' locality, 70 km south from Rincón de los Sauces (Neuquén Province). Hitherto, we recovered an almost complete left hind-limb (MAU-Pv-EO-629). In proximal view, the proximal epiphysis of the tibia is antero-posteriorly expanded and transversally compressed, as well as in Zapalasaurus Salgado, Carvalho and Garrido, 2006 and the rebbachisaurid from 'La Antena' (MMCH-PV-45), thus in contrast with most diplodocids and Titanosauriformes which present a more rounded proximal shape. In lateral view, the cnemial crest is rounded in shape, and directed anteriorly as in MMCH-PV-45, Zapalasaurus and other rebbachisaurids. The diaphysis is straight, as in other neosauropods, differing from derived titanosaurs where is more sinusoidal. The fibula is also straight, slightly longer than the tibia. The proximal epiphysis is oval in shape, while the distal one is 'D-shaped', as in most neosauropods. The astragalus is not clearly observable, being in articulation with the zeugopodium, while the calcaneus is not present. In the pes, the metatarsal III is the longest element of the sequence, while the digits III and IV show two altered phalanges. Pending the rescue of the remaining elements, we report here a new Neosauropoda specimen, probably belonging to Rebbachisauridae, from the Huincul Formation, whose sauropod record is represented by both rebbachisaurid and macronarian forms.

\section{A NEW HERRERASAURID FROM THE LATE TRIASSIC (CARNIAN), SANTA MARIA SUPERSE- QUENCE (HYPERODAPEDON ASSEMBLAGE ZONE), SOUTHERN BRAZIL}

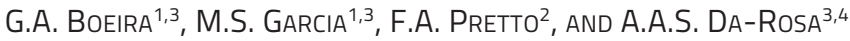 \\ ${ }^{1}$ Curso de Ciências Biológicas, Centro de Ciências Naturais e Exatas, Universidade Federal de Santa Maria. Av. Roraima, 1000, Bairro Camobi, \\ 97105-900 Santa Maria, Rio Grande do Sul, Brazil.boeirapaleo@gmail.com; maurissauro@mail.ufsm.br \\ ${ }^{2}$ Centro de Apoio à Pesquisa Paleontológica da Quarta Colônia, Universidade Federal de Santa Maria. Rua Maximiliano Vizzotto, 598, 97230- \\ 000 São João do Polêsine, Rio Grande do Sul, Brazil. flavio.pretto@ufsm.br \\ ${ }^{3}$ Laboratório de Estratigrafia e Paleobiologia, Centro de Ciências Naturais e Exatas, Departamento de Geociências, Universidade Federal de \\ Santa Maria. Av. Roraima, 1000, Bairro Camobi, 97105-900 Santa Maria, Rio Grande do Sul, Brazil. atila@smail.ufsm.br \\ ${ }^{4}$ Programa de Pós-Graduação em Biodiversidade Animal, Universidade Federal de Santa Maria. Av. Roraima, 1000, Bairro Camobi, $97105-900$ \\ Santa Maria, Rio Grande do Sul, Brazil.
}

We present a new herrerasaurid specimen from the Cerro da Alemoa outcrop (Santa Maria Supersequence, Carnian, Late Triassic), Santa Maria city, Brazil. UFSM 11608 is under preparation, already showing: associated skull and mandible; two cervical vertebrae; at least 12 presacral articulated vertebrae with associated ribs; both femora, tibiae and fibulae. Based on the exposed materials, it is possible to evaluate anatomical aspects that allow referring the specimen to Herrerasauridae (Dinosauria). UFSM 11608 has a large and reasonably complete skull, which is virtually as long as the femur, and possesses finely serrated (05 denticles/mm) zyphodont teeth. In lateral view, the cervical vertebrae exhibit trapezoidal-shapedcentra, with elongated prezygapophyses, when compared to the postzygapophyses. The neural spines are dorsoventrally short and lateromedially robust, the same for the dorsal vertebrae. They present grooves in both cranial and caudal surfaces, giving them an "H-shaped" transversal section. The distal end of the neural spines is expanded forming a spine table, typical of herrerasaurids. The femur shares many features with dinosauromorphs and early dinosaurs, like the sigmoid aspect and craniomedially projected head, rectangular in shape; in distal view, the medial condyle and the crista tibiofibularis are similar in size; the cranial margin and the medial condyle form a right angle. The continuity of the preparation will allow a more precise taxonomic assignment within Herrerasauridae. Yet, the scarcity of herrerasaurids from Brazil already gives importance to this specimen, which will prove an important element when comparing faunas of Triassic beds from Brazil (Santa Maria Supersequence) and Argentina (Ischigualasto Formation). 


\title{
REINTERPRETACIÓN MORFOLÓGICA Y ESTATUS TAXONÓMICO DE NOTOCAIMAN STROMERI RUSCONI (CROCODYLIA, ALLIGATOROIDEA) DEL PALEOCENO DE PATAGONIA, ARGENTINA
}

\author{
P. BONA ${ }^{1,3}$ Y F. BARRIOS ${ }^{2,3 *}$
}

'División Paleontología Vertebrados (Anexo Museo), Facultad de Ciencias Naturales y Museo, Universidad Nacional de La Plata. Calle 122 y 60, 1900 La Plata, Buenos Aires, Argentina.paulabona26@gmail.com

${ }^{2}$ Museo Provincial de Ciencias Naturales "Prof. Olsacher", Zapala; Universidad Nacional del Comahue. Ejército Argentino y Etcheluz, Q8340 Zapala Neuquén, Argentina. fbarrios84@gmail.com

${ }^{3}$ Consejo Nacional de Investigaciones Científicas y Técnicas (CONICET).

El registro fósil de aligatoroideos paleógenos en América del Sur es poco abundante y muy fragmentario. En este contexto, los ejemplares recuperados de distintos niveles del Paleoceno de Patagonia, Argentina (Formación Salamanca y Formación La Violetas, Paleoceno inferior y medio, respectivamente) son extremadamente relevantes, pues proveen información crucial acerca de la diversidad taxonómica y la disparidad morfológica temprana de este linaje de crocodilianos con representantes actuales. Al momento se reconocen 4 especies de Caimaninae: Eocaiman palaeocenicus Bona, Necrosuchus ionensis Simpson, Notocaiman stromeri Rusconi, y una nueva especie en revisión. Notocaiman stromeri está representado por un fragmento anterior de dentario izquierdo (PVL 752, holotipo), con parte de la hilera alveolar (del $1^{\circ}$ al $14^{\circ}$ alvéolo) y algunos dientes implantados parcialmente completos. Como resultado del estudio morfológico comparativo de este material podemos concluir que: 1) presenta el mismo contorno característico del dentario en vista lateral de Eocaiman Simpson (nivel del $1^{\circ} \mathrm{al} 4^{\circ}$ diente más bajo que el nivel del $11^{\circ}$ al $\left.12^{\circ}\right)$; 2) se diferencia de Necrosuchus por la extension más posterior de la sínfisis mandibular (por detras del $5^{\circ}$ alvéolo); 3) a diferencia de Eocaiman itaboraiensis Pinheiro et al. (del Paleoceno inferior de Brasil), y de E. cavernensis Simpson (del Eoceno de Patagonia), comparte con E. palaeocenicus el mismo patrón alveolar, sínfisis mandibuar extendida a nivel del $6^{\circ}$ alvéolo, y una mandíbula robusta. Estos resultados permiten considerar a Notocaiman stromeri como sinónimo de E. palaeocenicus y asignarlo, entonces, a Eocaiman, hipótesis que será contrastada mediante un análisis filogenético.

*Proyecto subsidiado por: PRESTAMO BID PICT 2016-0159.

\section{IMPLICANCIAS DEL DESARROLLO DENTAL Y DEL SENO MAXILAR EN EL MODELADO ÓSEO DEL MAXILAR SUPERIOR EN HUMANOS}

\author{
N. Brachetta-Aporta ${ }^{1,2}$ y L.A. D'addona ${ }^{1,2 *}$ \\ 'División Antropología, Facultad de Ciencias Naturales y Museo, Universidad Nacional de La Plata. B1900FWA La Plata, Argentina. \\ n.brachetta@gmail.com; daddona.la2.2@gmail.com \\ ${ }^{2}$ Consejo Nacional de Investigaciones Científicas y Técnicas (CONICET).
}

Los principales determinantes de la morfología del maxilar superior serían factores vinculados a la interacción entre el tejido óseo y órganos (e.g., músculos, senos paranasales) y estructuras asociadas (i.e., dientes), y a respuestas compensatorias a reorganizaciones espaciales. La acción conjunta de estos factores durante el desarrollo estimularía o inhibiría la diferenciación y actividad de las células involucradas en los procesos de formación y reabsorción de hueso -i.e., osteoblastos y osteoclastos- que constituyen el modelado óseo, así como desencadenaría movimientos pasivos -i.e., desplazamientos de crecimiento- producto del movimiento de tejidos adyacentes. El objetivo del presente trabajo es evaluar los cambios en el patrón de modelado óseo del maxilar superior anterior durante la ontogenia en humanos en función del desarrollo dental y del seno maxilar. Para ello se emplearon 19 individuos subadultos de 3 a 17 años procedentes de una muestra arqueológica del Valle inferior del río Chubut (Chubut, Argentina). Se registró la presencia de superficies de formación y reabsorción ósea, a través de la identificación de fibras de colágeno y lagunas de Howship respectivamente, empleando réplicas de alta resolución y microscopio de luz de incidencia con objetivo 20x. El desarrollo de la dentición y del seno maxilar se analizó mediante el empleo de imágenes digitales reconstruidas a partir de tomografías computadas de los cráneos. Se observó una tendencia de cambio en el patrón de modelado óseo con incremento de reabsorción en el proceso alveolar durante el recambio dental y en el proceso cigomático durante el desarrollo del seno maxilar.

\footnotetext{
*Proyecto subsidiado por "Rol del desarrollo en la evolución de la morfología craneodental de humanos y primates no humanos", Universidad Nacional de La Plata.
} 


\title{
NUEVOS MORFOTIPOS DE OSTEODERMOS DEL PLEISTOCENO MEDIO DE SAN PEDRO, PRO- VINCIA DE BUENOS AIRES, ARGENTINA
}

\author{
L. Brambilla ${ }^{1}$, J.L. Aguilar ${ }^{2}$ y J.A. Haro ${ }^{4,5,6}$ \\ ${ }^{1}$ Facultad de Ciencias Exactas, Ingeniería y Agrimensura, Universidad Nacional de Rosario. Av. Pellegrini 250, S2000BTP Rosario, Argentina. \\ Ibrambilla@fbioyf.unr.edu.ar \\ 2Museo Paleontológico de San Pedro "Fray Manuel de Torres". Carlos Pellegrini 145, 8625 San Pedro, Argentina. gcfosiles@gmail.com \\ 3Estomba 1237, C1427CPC, Ciudad Autónoma de Buenos Aires, Argentina. loessoide@gmail.com \\ 4Museo de Paleontología, Facultad de Ciencias Exactas, Físicas y Naturales, Universidad Nacional de Córdoba. Vélez Sarsfield 249, X5000JJC \\ Córdoba, Argentina. augustoharo@gmail.com \\ ${ }^{5}$ Cátedra de Paleontología, Facultad de Ciencias Exactas, Físicas y Naturales, Universidad Nacional de Córdoba. Vélez Sarsfield 1611, X5016GCA \\ Córdoba, Argentina. \\ ${ }^{6}$ Consejo Nacional de Investigaciones Científicas y Técnicas (CONICET).
}

Damos a conocer el hallazgo de osteodermos enigmáticos del Pleistoceno Medio (Piso/Edad Ensenadense) de San Pedro, Argentina. El material GCF13 comprende más de un centenar de osteodermos hallados junto a un grupo de fósiles: una mandíbula de Scelidotherium, fragmento de fémur de Toxodon y escápula de Glyptodon. Su longitud mayor varía entre 3 y 12,6 mm. Estos tamaños coinciden con los de algunos osteodermos de Mylodon, Paramylodon, y Glossotherium, aunque en estos géneros también se presentan osteodermos de mayor tamaño. La forma es bipiramidal octaédrica relativamente regular, a diferencia de los osteodermos polimórficos (subcirculares, arriñonados, piramidales, o irregulares) de los milodontinos mencionados. Sus caras son suaves con presencia de escasos forámenes y a veces atravesadas por delgadas incisiones, a diferencia de muchos osteodermos de milodontinos con marcas crateriformes. No hay asimetría u ornamentación que determine su orientación, a diferencia de los osteodermos de milodontinos o del carapacho, escudo cefálico, coraza ventral y cola de Cingulata. Se diferencian de osteodermos de los Testudinidae por poseer forma regularmente poliédrica, sin aplanamiento. No presentan la marcada rugosidad que tienen los de Eremotherium, pero su forma no aplanada los asemeja. Entre los milodontinos, se parecen más a los de Mylodon quienes poseen menor tamaño, menor aplanamiento y reducción de la ornamentación que los de Paramylodon y Glossotherium. Aunque los osteodermos estudiados están asociados a Scelidotherium estos han estado ausentes en especímenes completos, por lo que se propone que el conjunto GCF13 pertenecerían a algún milodontino de edad Ensenadense diferente de los taxones Lujanenses comparados.

\section{UN NUEVO MEGATHERIINAE (MAMMALIA, XENARTHRA) DEL PLEISTOCENO MEDIO DE LA REGIÓN PAMPEANA, ARGENTINA}

\author{
L. Brambilla ${ }^{1}$, D. Ibarra ${ }^{1}$, J.L. Aguilar ${ }^{2}$ y J. Simonini²
}

${ }^{1}$ Facultad de Ciencias Exactas, Ingeniería y Agrimensura, Universidad Nacional de Rosario. Av. Pellegrini 250, S2000BTP Rosario, Argentina. Ibrambilla@fbioyf.unr.edu.ar

2Museo Paleontológico de San Pedro "Fray Manuel de Torres". Carlos Pellegrini 145, 8625 San Pedro, Argentina. gcfosiles@gmail.com

Los Megatheriinae del Pleistoceno de Argentina son conocidos principalmente a partir de restos de Megatherium americanum Cuvier, 1796 provenientes de sedimentos de edad Lujanense. Por otra parte son escasos los restos del Pleistoceno Medio, siendo el holotipo de Megatherium gallardoi Ameghino y Kraglievich, 1921 el único ejemplar determinado a nivel específico. Aquí presentamos un nuevo Megatheriinae hallado en sedimentos de la Formación Ensenada en cercanías de San Pedro (Buenos Aires, Argentina). El nuevo taxón está representado por un fémur izquierdo (MPS 137) en cuyo extremo proximal solo se preserva parcialmente el trocánter mayor. El fémur es de gran tamaño como en $M$. americanum o $M$. gaIlardoi; y el ectepicóndilo es masivo, prominente y su borde es redondeado como en Pyramiodontherium Rovereto, 1914. Mediante comparación anatómica y análisis morfogeométrico de la región distal se observa que el cóndilo lateral del ejemplar MPS 137 es significativamente robusto, característica que lo asemeja a ejemplares de Pyramiodontherium en los cuales el cóndilo lateral se acerca en tamaño al cóndilo medial. Asimismo, a diferencia de M. americanum y M. gallardoi, el borde medial de la tróclea patelar está notablemente elevado respecto al borde lateral, tal como ocurre en Pyramiodontherium. Se amplía a partir de este hallazgo la diversidad de los Megatheriinae del Pleistoceno Medio de Argentina siendo el nuevo taxón el más grande y reciente representante del género Pyramiodontherium. 


\title{
ENAMEL MICROSTRUCTURE OF PERMANENT AND DECIDUOUS CHEEK TEETH IN TOXODON OWEN, 1837: DENTAL DEVELOPMENT AND FUNCTIONAL IMPLICATIONS
}

\begin{abstract}
P.R. Braunn ${ }^{1}$, J. Ferigolo ${ }^{1,2}$, and A.M. Ribeiro ${ }^{1,2 *}$
${ }^{1}$ Universidade Federal do Rio Grande do Sul, Instituto de Geociências,Programa de Pós-Graduação em Geociências. Av. Bento Gonçalves 9500, 91501-970 Porto Alegre, Brazil.pbraunn@gmail.com

${ }^{2}$ Fundação Zoobotânica do Rio Grande do Sul, Museu de Ciências Naturais, Secção de Paleontologia. Av. Dr. Salvador França, 1427, $90690-000$ Porto Alegre, Brazil.jorge-ferigolo@fzb.rs.gov.br; ana-ribeiro@fzb.rs.gov.br

The study of dental tissues is of great importance to understand life-history and evolution of fossil mammals, and for that widely used in taxonomic, phylogenetic, paleobiological, and paleoecological studies. Enamel microstructure in permanent and deciduous supper and lower premolars and molars of Toxodon Owen, 1837, a notoungulate from the Pleistocene of South America was analysed by scanning electron microscopy, and under optical microscopy. The material includes ten specimens from Pleistocene deposits of São Paulo and Rio Grande do Sul States, Brazil. Permanent cheek teeth exhibited schmelzmuster with three enamel types, of which the relative thickness, orientation of prisms and interprismatic matrix varies: an innermost layer associated to enamel-dentine junction (EDJ), corresponding to modified radial enamel, an intermediate layer formed by decussated prisms, consisting of Hunter-Schreger bands (HSB), and a layer of radial enamel, next to the enamel outer surface. Absence of HSB was observed in the lingual enamel folds of upper and lower permanent molars, while on the buccal face of them, there was a well-marked decussation of prisms and differentiation of enamel layers. Upper and lower deciduous teeth exhibited HSB weakly developed, indicating early stages of enamel development. Neonatal Line was observed in deciduous teeth almost parallel to the EDJ. This hypomineralized line of enamel could be related to the biological stress occurred during the birth event in these animals. The HSB patterns probably indicate the presence of decussation prisms in regions exposed to the greatest functional demand in Toxodon.
\end{abstract}

${ }^{*}$ Financial supportby Conselho Nacional de Desenvolvimento Científico e Tecnológico (CNPq).

\section{REGISTRO DE UN INDIVIDUO JUVENIL DE NOTROTHERIDO (MAMMALIA, XENARTHRA) EN LA FORMACIÓN LOMA DE LAS TAPIAS, MIOCENO SUPERIOR DE SAN JUAN, ARGENTINA}

\author{
M.G. Campos ${ }^{1}$, M. Del V. Valderrama ${ }^{1}$, V.E. Mulet $T^{1,2}$ Y V.H. Contreras ${ }^{1,3,4}$
}

${ }^{1}$ Colección Paleontológica del Instituto de Geología Dr. E. P. Aparicio, Facultad de Ciencias Exactas, Físicas y Naturales, Universidad Nacional San Juan. Ignacio de la Roza 590 (Oeste), J5402DCS Rivadavia, San Juan, Argentina.campos.mauricio66@yahoo.com.ar; mariava82@yahoo.com.ar; vcontre@unsj-cuim.edu.ar; vmulet@unsjcuim.edu.ar

${ }^{2}$ Consejo Nacional de Investigaciones Científicas y Tecnológicas (CONICET).

${ }^{3}$ Gabinete de Estratigrafía, Instituto de Geología Dr. E. P. Aparicio, Facultad de Ciencias Exactas, Físicas y Naturales, Universidad Nacional San Juan. Ignacio de la Roza 590 (Oeste), J5402DCS, Rivadavia, San Juan, Argentina.

${ }^{4}$ Departamento de Geología, Facultad de Ciencias Exactas, Físicas y Naturales, Universidad Nacional San Juan.Ignacio de la Roza 590 (Oeste), J5402DCS, Rivadavia, San Juan, Argentina.

El espécimen que se describe, INGEO-PV-002, procede de los niveles basales del Miembro Areniscas Albardón, Formación Loma de Las Tapias (Mioceno superior), en la provincia de San Juan, Argentina. Los niveles estratigráficos indicados tienen una antigüedad que supera los 7,8 Ma según la información disponible, y corresponden al Tortoniano medio-tardío. Este espécimen, está representado por la mayor parte del dentario derecho, con parte de las raíces de tres molariformes y vestigios de un caniniforme. La morfología dentaria presenta rasgos típicos de los Nothrotheriinae, los molariformes con forma rectangular a casi trapezoidal y con surcos longitudinales labiales y linguales, y los caracteres dentales conservados más importantes de este espécimen son: longitud máxima de serie m1-m3: 24,48 mm; un diastema de longitud estimada de 4,38 mm; índice Largo del Diastema/Largo de la Serie Dentaria: 17,89 mm, lo que permite asignar por estos parámetros el espécimen INGEO-PV-002, a un individuo inmaduro del género Xyophorus Ameghino, 1887 (Nothrotheriidae, Megatherioidea, Xenarthra, Mammalia), que se suma al elenco faunístico de Edad Chasiquense, documentado previamente para Loma de Las Tapias (San Juan). Como conclusiones resultantes, se destaca la ampliación de la distribución geográfica del género y la implicancia paleoecológica del hallazgo, por tratarse de un perezoso con marcadas adaptaciones arborícolas. 


\title{
HISTOLOGÍA ÓSEA DE ESTRUCTURAS DE INSERCIÓN DENTAL EN UN TERÓPODO ABELISAU- ROIDEA DE PATAGONIA
}

\author{
I.A. CERDA ${ }^{1}$ Y J.D. PORFIRI ${ }^{2}$
}

${ }^{1}$ Instituto de Investigaciones en Paleobiología y Geología (IIPG)-Consejo Nacional de Investigaciones Científicas y Tecnológicas (CONICET), Universidad Nacional de Río Negro, Museo Provincial Carlos Ameghino. Belgrano 1700, Paraje Pichi Ruca (predio Marabunta), R8324CZH Cipolletti, Río Negro, Argentina.nachocerda6@yahoo.com.ar

${ }^{2}$ Museo de Ciencias Naturales (Subsuelo Biblioteca Central), Universidad Nacional del Comahue. Cátedra de Reptiles Mesozoicos, Facultad de Ingeniería, Universidad Nacional del Comahue. Buenos Aires 1400, Q8300IBX Neuquén, Argentina.

jporfiri@gmail.com; juan.porfiri@central.uncoma.edu.ar

Gran parte de los estudios histológicos enfocados en estructuras dentales en dinosaurios se basan principalmente en el análisis del esmalte y la dentina. De esta manera, los análisis que integren a los tejidos de inserción dental (i.e., cemento, ligamento periodontal y hueso alveolar) son sumamente escasos. En el presente trabajo, se estudia la histología de las estructuras de inserción dental en un Abelisauroidea del Cretácico Tardío de Patagonia, con el objeto de ampliar el conocimiento en cuanto a la evolución de estas las estructuras en dinosaurios. Se trata este del primer estudio histológico de inserciones dentarias en un Ceratosauria. El material en estudio (MUCPv-1151), proviene de la localidad Aguada Pichana (ubicada a $170 \mathrm{~km}$ al NO de Neuquén capital), en afloramientos de la Formación Candeleros (Grupo Neuquén). Se efectuaron secciones transversales y longitudinales a un fragmento correspondiente al dentario derecho. Mientras que en la corona de los dientes se distingue tanto esmalte como dentina, solo esta última se observa a nivel de la raíz. Cubriendo las raíces se desarrolla una delgada capa de cemento acelular, la cual es seguida de una capa de cemento celular. Esta última capa exhibe una clara birrefringencia bajo luz polarizada, indicando la presencia de fibras colágenas correspondientes al ligamento periodontal. Por su parte, hueso alveolar de tipo entretejido reviste las paredes de los alvéolos. La histología de las estructuras de inserción es idéntica a la reportada en el terópodo basal Coelophysisbauri Cope, 1887, esto sugiere que este rasgo es altamente conservativo dentro de Theropoda.

\section{NEW INFORMATION ON THE CRANIOFACIAL ANATOMY OF CARNOTAURUSSASTREI(THEROPODA, ABELISAURIDAE)}

\section{M.A. Cerronil ${ }^{1,2}$, ANd J.I. CANALE ${ }^{1,3}$}

${ }^{1}$ Consejo Nacional de Investigaciones Científicas y Tecnológicas (CONICET).

¿Laboratorio de Anatomía Comparada y Evolución de los Vertebrados, Museo Argentino de Ciencias Naturales "Bernardino Rivadavia". Av. Ángel Gallardo 470, C1405DJR Ciudad Autónoma de Buenos Aires, Argentina. mauricio.cerroni@gmail.com

3Área Laboratorio e Investigación, Museo Paleontológico "Ernesto Bachmann". 8311 Villa El Chocón, Neuquén, Argentina.

Carnotaurus sastrei Bonaparte, 1985 is a theropod dinosaur, perhaps the most iconic representative of the Abelisauridae. It is known by a fairly complete specimen, recovered from Upper Cretaceous beds of Patagonia. A re-evaluation of the wellpreserved skull of Carnotaurus including a detailed description of each bone, CT scans analyses and comparisons with several abelisaurid taxa expands the previous knowledge of this theropod; adding novel information concerning bones that remained undescribed such the palatal bones (i.e., palatines, pterygoids, and ectopterygoids). This study allowed the recognition of several features, including some new potential autapomorphies such as: antorbital fenestra dorsoventrally enlarged, medioventral recess on the pterygoid ramus of the quadrate, jugal deep and anteroposteriorly short, lateral fossa of vomeropalatine process of pterygoid. Among the features shared by abelisaurids, some of them includes: lateral fossa of the squamosal, lanceolate vomeropterygoid process of palatine, and angular process of the surangular. Furthermore, the CT scans revealed some pneumatic recesses in the lacrimal; similar to those present in Majungasaurus Depéret, 1896 and the tetanuran Allosaurus Marsh, 1877. Although, the most striking feature is a small pneumatic recess in the base of each frontal horn; it is difficult to trace the origin of the latter but likely was related to the lacrimal recesses. Frontal recesses are also present in Majungasaurus and Ceratosaurus Marsh, 1884. In sum, Carnotaurus provides one of the most complete skulls within abelisaurids, which provides several features of potential phylogenetic value and raises new questions about the presence and variability of pneumatic structures among ceratosaurs. 


\title{
THE PHYLOGENETIC AFFINITIES OF AFROMIMUS TENERENSIS SERENO, 2017
}

\author{
M.A. Cerronin ${ }^{1,2}$, F.L. Agnolín ${ }^{1,2,3}$, F. Brissón Egli1 ${ }^{1,3}$, and F.E. Novas ${ }^{1,3}$ \\ 'Laboratorio de Anatomía Comparada y Evolución de los Vertebrados, Museo Argentino de Ciencias Naturales "Bernardino Rivadavia". \\ Av. Ángel Gallardo 470, C1405DJR Ciudad Autónoma de Buenos Aires, Argentina.mauricio.cerroni@gmail.com \\ 2Fundación de Historia Natural "Félix de Azara", Departamento de Ciencias Naturales y Antropología, Centro de Estudios Biomédicos, Bio- \\ tecnológicos, Ambientales y Diagnóstico (CEBBAD)-Universidad Maimónides. Hidalgo 775, Piso 7, C1405BDB Ciudad Autónoma de Buenos \\ Aires, Argentina. \\ ${ }^{3}$ Consejo Nacional de Investigaciones Científicas y Tecnológicas (CONICET).
}

Afromimus tenerensis Sereno, 2017 was recently described on the basis of an incomplete skeleton coming from the Lower Cretaceous of Niger. The specimen was originally described as a basal ornithomimosaur. This clade of dinosaurs is abundant in Laurasia, and thus, its record in Gondwana has deep biogeographical implicances. However, an overview of the description of the specimen indicates that it may belong to Abelisauroidea. It shares with the latter clade: tibia with fibular crest continuous with proximal end, large elliptical scar on posterior surface of the tibia (absent in ornithomimosaurs), relatively low ascending process of the astragalus, which is sub-rectangular in contour, large iliofibular tubercle of fibula, pedal phalanx with lateral bump and ' $V$ '-shaped lateral furrows and lacking flexor tubercle, distal caudal vertebrae with excavated fossae for prezygapophyses (convergently acquired with ornithomimosaurs), and chevrons anteroposteriorly narrow with fused pedicels. These features are present in several ceratosaurs such as Ceratosaurus Marsh, 1884 and abelisauroids (e.g., Skorpiovenator Canale et al., 2008). A noticeable feature of Afromimus shared with some abelisauroids, is that distal caudal centrum bears a cranial surface wider than high; also present in Elaphrosaurus Janensch, 1920 and $\mathrm{Li}$ gabueino Bonaparte, 1996. A phylogenetic analysis was conducted using Winclada based on the data matrix of Carrano et al. (2012) to test the phylogenetical position of Afromimus among theropods. A strict consensus tree recovered Afromimus as an abelisauroid, particularly as the sister-taxon of Masiakasaurus Sampson et al., 2001. This result is similar to that convergently acquired by Cau, pers. com. (2018).

\section{TIBIA DE MEGATHERIUM (MAMMALIA, XENARTHRA) DEL VALLE DEL RÍO QUINTO (SAN LUIS, ARGENTINA)}

\author{
J. Chiesa ${ }^{1}$, J. Krapovickas ${ }^{2}$, A. Tauber ${ }^{2}$ y G. Heider ${ }^{3 *}$ \\ 1Departamento de Geología, Facultad de Ciencias Físico Matemáticas y Naturales, Universidad Nacional de San Luis. Ejército de los Andes 950 , \\ D5700HHW San Luis, Argentina. chiesa@unsl.edu.ar \\ Escuela de Geología, Facultad de Ciencias Exactas, Físicas y Naturales, Universidad Nacional de Córdoba. Av. Vélez Sarsfield 1611, X5016GCA \\ Córdoba, Argentina. \\ ${ }^{3}$ Centro Científico Tecnológico (CCT) San Luis-Consejo Nacional de Investigaciones Científicas y Tecnológicas. Almirante Brown 907, D5700HF0 \\ San Luis, Argentina. guillermoheider@hotmail.com
}

Se aporta información referida a restos de megafauna y aspectos sedimentológicos de los depósitos del Pleistoceno Tardío en el norte de la Planicie Medanosa Austral (Formación El Chulengo, arenas y limos, friables), en interacción con el sistema fluvial del río Quinto (Formación Fraga, gravas y arenas, moderadamente friables). El fósil corresponde a una tibia derecha (UNSL MIC-V909), robusta y larga (>70 cm), y se observan sus diáfisis y epífisis fusionadas, por lo que correspondería a un espécimen adulto de Megatherium sp. La tibia es aplanada antero-dorsalmente, con un diámetro lateral en su epífisis de $14,9 \mathrm{~cm}$ y en sus diáfisis proximal y distal, de 31,4 y 28,4 cm, respectivamente. En la vista proximal, se observa el cóndilo femoral interno, de forma cóncava y sección oval. Mientras en la vista distal, la articulación con los huesos tarsales se encuentra dividida en dos superficies ligeramente cóncavas, separadas por una cresta intercloclear poco pronunciada, diferenciándose de Mylodon y Scelidotherium, por carecer de una faceta adicional para la fíbula y las facetas de articulación son muy profundas. En Mylodon, la tibia es proporcionalmente más corta y robusta. Los depósitos vinculados al clímax del Último Máximo Glacial y la megafauna de la edad-mamífero Lujanense, tienen una amplia distribución estratigráfica en la provincia de San Luis, aquellos de carácter eólico con edades numéricas comprendidas entre ca. 30 ka y 20 ka, mientras que los fluviales Ilegan a $12 \mathrm{ka}$.

*Proyecto Geología del Neógeno y Cuaternario de San Luis (3-2-0514 CyT-UNSL). 


\title{
NUEVA METODOLOGÍA PARA LA CLASIFICACIÓN DE MOLARIFORMES EN CINGULATA GLYPTO- DONTIDAE (XENARTHRA, MAMMALIA)
}

\author{
F. Cuadrelli' , F.I. Contreras ${ }^{1}$ y A.E. Zurita ${ }^{1}$
}

${ }^{1}$ Centro de Ecología Aplicada del Litoral (CECOAL)-Consejo Nacional de Investigaciones Científicas y Tecnológicas (CONICET) y Universidad Nacional del Nordeste. Ruta 5, km 2,5, 3400 Corrientes, Argentina. f.cuadrelli@gmail.com

Los Mammalia Xenarthra constituyen un clado endémico de América, con un importante y extenso registro fósil. Uno de sus rasgos más distintivos es su dentición, cuya morfología y ontogenia genera dificultades a la hora de establecer homologías con los demás mamíferos placentarios. Uno de los clados más interesantes de Xenarthra son los Cingulata Glyptodontidae. A nivel dentario, existe una tendencia a la trilobulación, particularmente a partir del tercer o cuarto molariforme, en tanto que los tres primeros varían entre los diferentes grupos. Este carácter ha sido utilizado en estudios sistemáticos, filogenéticos y morfo-funcionales. Aquí proponemos la aplicación para este clado del índice de circularidad morfométrica (ICM), el cual permite cuantificar descripciones cualitativas y generalmente subjetivas. La clasificación dentaria presentada está basada en el análisis de los tres primeros molariformes superiores en 22 especímenes representantes de las subfamilias Propalaehoplophorinae, "Hoplophorinae" y Glyptodontinae. Los valores inferiores a 1,04 fueron considerados como circulares (Propalaehoplophorus Ameghino; Doedicurus Burmeister; Eosclerocalyptus C. Ameghino; Neosclerocalyptus Paula-Couto); valores entre 1,05 y 1,1 se clasificaron como elípticos (Eucinepelthus, Boreostemma Carlini et al. y Neosclerocalyptus); valores entre 1,11 y 1,16 semilunares (Cochlops, Eosclerocalyptus, Panochthus Burmeister y Neosclerocalyptus Paula-Couto); valores desde 1,17 hasta 1,22 sub-trilobulados (Glyptodon munizi Ameghino); valores entre 1,23 y 1,28 trilobulados (Panochthus Burmeister) y superiores a 1,29 trilobulados escotaos (Glyptodon reticulatus Owen). En este sentido, cabe destacar la notable variabilidad dentro de un mismo taxón, en relación a la complejidad del Mf1, e.g., molariformes circulares, subcirculares o trilobulados en Eosclerocalyptus, o subtrilobulados a trilobulados escotados en Panochthus.

\section{PALEONTOLOGICAL HERITAGE VS. URBAN GROWTH: THE FATE OF TRIASSIC FOSSILS IN SOUTH- ERN BRAZIL}

\author{
Á.A.S. DA-RosA ${ }^{1}$
}

1Programa de Pós-Graduação Profissional em Patrimônio Cultural, Centro de Ciências Sociais e Humanas, Universidade Federal de Santa Maria, Av. Roraima, 1000, Bairro Camobi, 97105-900, Santa Maria, Rio Grande do Sul, Brasil. atila@smail.ufsm.br

The central region of Rio Grande do Sul State, southern Brazil, records Triassic fossiliferous sedimentary rocks, between 250 and 200 million years ago, with archosaurs, dicynodonts, cynodonts, procolophonoids, rhynchosaurs and dinosaurs in massive reddish mudstones of the Santa Maria Supersequence (SMS), as well as leaf imprints, conchostracs and insects in argillaceous levels or intraclasts in fluvial sandstones of the same sequence. The Paleontological Route intends to integrate municipalities along a touristic/educational action, along with regional development, which in turn leads to constructions, mainly at the urban area. The preservation of fossiliferous sites is linked to subsoil intervention, such as excavations, drillings, soil remotion, etc. Despite constituting an important paleobiodiversity, this Paleontological Heritage of international importance is presently fragile, in need of concrete actions towards its preservation.

\section{A NEW MATERIAL OF 'RAUISUCHIA' TO THE CANDELÁRIA SEQUENCE (CARNIAN TO SANTA MARIA SUPERSEQUENCE), LATE TRIASSIC OFSOUTHERN BRAZIL}

\author{
L.V.S. DAMkE ${ }^{1}$, M.S. GarCIA ${ }^{1}$, and Á.A.S. Da RoSA ${ }^{1 *}$ \\ 'Laboratório de Estratigrafia e Paleobiologia, Departamento de Geociências, Universidade Federal de Santa Maria. Av. Roraima, 1000, Bairro \\ Camobi, 97105-900 Santa Maria, Rio Grande do Sul, Brasil. S.lisiesd@hotmail.com; atila@smail.ufsm.br; mauriciossauro@gmail.com \\ 'Rauisuchians' are a group of Pseudosuchia whose systematics are widely debated, traditionally classifying them by the \\ presence of recurved teeth, large skulls, and cosmopolitan distribution during the Triassic. The only pseudosuchians re- \\ ferred to the Hyperodapedon Assemblage Zone (AZ) are: Rauisuchus tiradentes Huene, 1938; Aetosauroides scagliai \\ Casamiquela, 1960; Aetobarbakinoides brasiliensis Desojo, 2012; and Polesinesuchus aurelioi Roberto-da-Silva, 2014. Here \\ we describe a new material collected at Faixa Nova - Cerrito III outcrop (29 42' 22.34" S; 53 47' 12.14" W), Hyperodapedon
}


AZ (Carnian), which consists in a rib and a right maxilla with nearly $20 \mathrm{~cm}$ in preserved rostral caudal length (UFSM11617), without preserved teeth. In lateral view, maxillary body is $4.6 \mathrm{~cm}$ height, prior the ascending process, and $1.7 \mathrm{~cm}$ in the preserved posterior region, in a subtriangular shape. The material introduced here is still under preparation, but the presence of palatal process of the maxilla and the ascending process can be seen, the latter is broken near the preorbital sinus, visible in medial view. Eleven alveoli are evident, being the largest one $2.3 \mathrm{~cm}$ of anteroposterior length and $1.5 \mathrm{~cm}$ of labiolingual dimension. Some non-fused, triangular interdental plates are observable. It is not possible to refer the material to known taxa, although it resembles other 'rauisuchians'. The ongoing preparation may clarify the shape of the antorbital cavity and the presence of maxillary crest and associated foramina.

${ }^{*}$ Funds by LVSD, Programa de Educação Tutorial FNDE; MSG, CNPq.

\title{
GLYPTODON MUNIZI AMEGHINO Y PANOCHTHUS INTERMEDIUS LYDEKKER (XENARTHRA, GLYPTODONTIDAE): DOS NUEVOS REGISTROS PARA LA BASE DE LA FORMACIÓN LA ESPE- RANZA EN LA SIERRAS DE OLAVARRÍA, PROVINCIA DE BUENOS AIRES, ARGENTINA
}

\begin{abstract}
M. De Los Reyes ${ }^{1}$, M. Zamorano ${ }^{1,3}$, A.E. Zurita ${ }^{2,3}$, D.G. Poire ${ }^{4}$ y M.J. Arrouy ${ }^{4 *}$
'División Paleontología Vertebrados, Museo de La Plata, Facultad de Ciencias Naturales y Museo, Universidad Nacional de La Plata. Paseo del Bosque s/n, B1900FWA La Plata, Argentina.mdelosreyes@fcnym.unlp.edu.ar

${ }^{2}$ Centro de Ecología Aplicada del Litoral (CECOAL)-Consejo Nacional de Investigaciones Científicas y Tecnológicas (CONICET) y Universidad Nacional del Nordeste. Ruta 5, km 2,5, 3400 Corrientes, Argentina.

${ }^{3}$ Consejo Nacional de Investigaciones Científicas y Tecnológicas (CONICET).

${ }^{4}$ Centro de Investigaciones Geológicas (CIG), Universidad Nacional de La Plata- Consejo Nacional de Investigaciones Científicas y Tecnológicas (CONICET). Diagonal 113 y calle 64, 1900 La Plata, Argentina.

En los últimos diez años, en las Serranías de Olavarría (provincia de Buenos Aires) se han realizado considerables avances en el conocimiento sedimentológico, estratigráfico y paleontológico; donde, además, se han podido determinar nuevas unidades litoestratigráficas y su correspondencia biocronológica, incluyendo la exhumación de un gran número de fósiles. En este trabajo se dan a conocer dos nuevos registros de Xenarthra Glyptodontidae, Glyptodon munizi Ameghino, 1881 y Panochthus intermedius Lydekker, 1895. Los taxones aquí estudiados provienen de la base de la Formación La Esperanza, caracterizada sedimentológicamente por la presencia de cuatro subniveles. Ellos incluyen sedimentos areno-limosos, con algunos clastos psefíticos y muñecos de tosca. Hacia la base se observan lentes conglomerádicos mientras que en los niveles superiores existen cárcavas y una gran cantidad de paleocuevas de mediano y pequeño tamaño. Panochthus intermedius está representado por una gran porción de la región póstero-dorsal de la coraza dorsal (CCA*-41) que muestra una figura central rodeada de hasta siete hileras de figuritas periféricas, en tanto que hacia el dorso es posible observar un patrón claramente reticular. A su vez, G. munizi incluye varios restos asociados de la coraza dorsal (CCA-50); los osteodermos muestran en su superficie expuesta una figura central de gran tamaño con una con una depresión en su parte central. Desde una perspectiva bioestratigráfica, la presencia de estos taxones en la Formación Esperanza sugiere, por primera vez, la presencia de niveles asignables al Piso/Edad Ensenadense (Pleistoceno Temprano-Medio) para la base de esta unidad.
\end{abstract}

${ }^{*}$ CCA: Colección Cementos Avellaneda (Registrada en el Centro de Registro del Patrimonio Paleontológico y Arqueológico perteneciente a la Dirección Provincial de Museos y Preservación Patrimonial del Gobierno de la Provincia de Buenos Aires).

\section{ANATOMY AND SYSTEMATIC OF PROSQUALODON AUSTRALIS (CETACEA, ODONTOCETI) FROM THE EARLY MIOCENE OF PATAGONIA}

\author{
C.M. GAETÁN ${ }^{1}$, M.R. BuONO², AND L.C. GAETANO ${ }^{3,4}$ \\ ${ }^{1}$ maxgaetan88@gmail.com \\ ${ }^{2}$ Instituto Patagónico de Geología y Paleontología (IPGP), Centro Nacional Patagónico (CENPAT)-Consejo Nacional de Investigaciones Cien- \\ tíficas y Tecnológicas (CONICET). Boulevard Brown 2915, U9120ACD Puerto Madryn, Chubut, Argentina. m.buono8@gmail.com \\ ${ }^{3}$ Departamento de Ciencias Geológicas, Facultad de Ciencias Exactas y Naturales, Instituto de Estudios Andinos "Don Pablo Groeber" (IDEAN), \\ Universidad de Buenos Aires-Consejo Nacional de Investigaciones Científicas y Tecnológicas (CONICET). Intendente Güiraldes 2160, Ciudad \\ Universitaria - Pabellón II, C1428EGA Ciudad Autónoma de Buenos Aires, Argentina. leandrogaetano@gmail.com \\ ${ }^{4}$ Evolutionary Studies Institute, University of the Witwatersrand. Private Bag 3, WITS 2050, Johannesburg, South Africa.
}


The extinct odontocete Prosqualodon australis Lydekker, 1894 (Early Miocene, Gaiman Formation, Chubut Province, Argentina) is for the first time described in-depth based on the holotype (MLP 5-8, a partial skull) and a referred specimen (MLP 5-9, an almost complete skull; Cabrera, 1926). Besides, the first phylogenetic analysis including this species as an operational taxonomic unit itself is presented, considering a comprehensive morphological matrix of odontocetes. The peculiar morphology of the anterior projection of the antorbital process along with plesiomorphic dental features (such as well-marked heterodont, large lateromedially compressed teeth with long crowns, reticulated enamel, and birradiculated teeth in the maxillae) are proposed to diagnose the species. Also, the body length of $P$. australis is inferred to vary at least between 2 and $3 \mathrm{~m}$ between the juvenile and the adult stages. Comparative anatomical studies show ontogenetic and intraspecific differences between the specimens analyzed. The phylogenetic analyses show $P$. australis as a stem-Odontoceti and Prosqualodon as a paraphyletic genus. The relative basal position of $P$. australis in the optimal trees recovered may respond to plesiomorphic skull characteristics. Also due to the lack of preserved earbones in $P$. australis, the future description of tympano-periotic bones might lead to new phylogenetic results.

\title{
MORPHOLOGICAL VARIATION IN THE ILIUM OF SATURNALIIN SAUROPODOMORPHS (DI- NOSAURIA, SAURISCHIA) -NEW SPECIMENS FROM THE LATE TRIASSIC (CARNIAN) OF SOUTH- ERN BRAZIL
}

\author{
M.S. Garcia ${ }^{1,4}$, R.T. Müller ${ }^{2,3}$, F.A. Pretto ${ }^{3}$, A.A.S. Da-Rosa ${ }^{2,4}$, and S. Dias-Da-Silva ${ }^{2 *}$ \\ ${ }^{1}$ Curso de Ciências Biológicas, Centro de Ciências Naturais e Exatas, Universidade Federal de Santa Maria. Av. Roraima, 1000, Bairro Camobi, \\ 97105-900 Santa Maria, Rio Grande do Sul, Brazil.maurissauro@mail.ufsm.br \\ ${ }^{2}$ Programa de Pós-Graduação em Biodiversidade Animal, Universidade Federal de Santa Maria. Av. Roraima, 1000, Bairro Camobi, $97105-900$ \\ Santa Maria, Rio Grande do Sul, Brazil.rodrigotm@hotmail.com; atiladarosa@smail.ufsm.br; paleosp@gmail.com \\ ${ }^{3}$ Centro de Apoio à Pesquisa Paleontológica da Quarta Colônia, Universidade Federal de Santa Maria. Rua Maximiliano Vizzotto, 598, $97230-$ \\ 000 São João do Polêsine, Rio Grande do Sul, Brazil. flavio.pretto@ufsm.br \\ 4Laboratório de Estratigrafia e Paleobiologia, Centro de Ciências Naturais e Exatas, Departamento de Geociências, Universidade Federal de \\ Santa Maria. Av. Roraima, 1000, Bairro Camobi, 97105-900 Santa Maria, Rio Grande do Sul, Brazil.
}

Saturnaliinae is a group of Carnian sauropodomorphs, mainly represented by Chromogisaurus Ezcurra, 2010 and Saturnalia Langer, 1999. Pelvic girdle elements are frequently preserved in its representatives, which are characterized by conspicuous rugosities in the iliac dorsal portion, representing muscle scars (iliac blade rugosity, IBR; post-acetabular rugosity, POR, preacetabular rugosity, PRR). Though referred as some of the key-characters of Saturnaliinae in the literature, these rugosities also occur in other dinosauriforms (herrerasaurids, silesaurids), whereas in sauropodomorphs they may be restricted to Carnian forms. We report variation in these features among specimens of Saturnalia (MCP 3844-PV; MCP 3845-PV; MCP 3846-PV), and new saturnaliin specimens (UFSM 11612; CAPPA/UFSM 0200) that may shed light on this issue. All specimens are similar in body size and preserve partial ilia. CAPPA/UFSM 0200 and MCP 3845-PV are the only specimens that preserve all three rugosities, those being robust and well-defined. The area that would bear the PRR is broken away in Chromogisaurus and MCP 3844-PV, but they have both POR and IBR. UFSM 11612 lacks the preacetabular ala and the iliac blade, presenting faint striations on the homologous area of POR. MCP 3846-PV does not present rugosities, contrasting with the aforementioned specimens. As the latter specimen is referred to Saturnalia (as well as 3844-PV and MCP 3845-PV, which present robust scars), the diagnostic importance of morphological variation in the expression of iliac muscle scars should be taken with caution, given the alleged importance of these traits as some of the key-characters to define Saturnaliinae.

\footnotetext{
*Project supported by a Fundação de Amparo à Pesquisa do Estado do Rio Grande do Sul (FAPERGS) scholarship (to M.S.G.), a Coordenação de Aperfeiçoamento de Pessoal de Nivel Superior (CAPES) scholarship (to R.T.M.) and by Conselho Nacional de Desenvolvimento Científco e Tecnológico [CNPq; research grant to S.D.S, process number 306352/2016-8].
} 


\title{
A NEW LAGERPETID (ORNITHODIRA, DINOSAUROMORPHA) FROM THE UPPER TRIASSIC (CARNIAN OF THE SANTA MARIA SUPERSEQUENCE) OF SOUTHERN BRAZIL
}

\author{
M.S. Garcia ${ }^{1,4}$, R.T. MÜllek ${ }^{2,3}$, S. Dias-DA-Silva², ANd A.S. Da-RoSA $2,4 *$ \\ ${ }^{1}$ Curso de Ciências Biológicas, Centro de Ciências Naturais e Exatas, Universidade Federal de Santa Maria. Av. Roraima, 1000, Bairro Camobi, \\ 97105-900 Santa Maria, Rio Grande do Sul, Brazil.maurissauro@mail.ufsm.br \\ 2Programa de Pós-Graduação em Biodiversidade Animal, Universidade Federal de Santa Maria. Av. Roraima, 1000, Bairro Camobi, $97105-900$ \\ Santa Maria, Rio Grande do Sul, Brazil.rodrigotm@hotmail.com; atiladarosa@smail.ufsm.br; paleosp@gmail.com \\ ${ }^{3}$ Centro de Apoio à Pesquisa Paleontológica da Quarta Colônia, Universidade Federal de Santa Maria. Rua Maximiliano Vizzotto, 598, $97230-$ \\ 000 São João do Polêsine, Rio Grande do Sul, Brazil. \\ ${ }^{4}$ Laboratório de Estratigrafia e Paleobiologia, Centro de Ciências Naturais e Exatas, Departamento de Geociências, Universidade Federal de \\ Santa Maria. Av. Roraima, 1000, Bairro Camobi, 97105-900 Santa Maria, Rio Grande do Sul, Brazil.
}

Among dinosauromorphs, one of the most enigmatic clades is the Lagerpetidae. Only recently these small and cursorial forms are receiving the appropriate attention. New specimens are shedding light on their anatomy and helping to establish evolutionary hypotheses. Most lagerpetids are known only from their hindlimbs, specially the femur, as is the case of the specimen herein analyzed. UFSM 11611 comprises the distal portion $(22 \mathrm{~mm}$ of preserved length and $22 \mathrm{~mm}$ of distal width) of a left femur. It was collected in the Cerro da Alemoa outcrop in the city of Santa Maria (Hyperodapedon Assemblage Zone of the Candelária Sequence (Carnian of the Santa Maria Supersequence). This locality is radioisotopically dated as $233.23 \pm 0.73 \mathrm{Ma}$ and comprises the type-locality of the sauropodomorph dinosaur Saturnalia tupiniquim Langer, 1999. An expanded crista tibiofibularis supports the lagerpetid affinity of UFSM 11611, which was recovered as a lagerpetid in three phylogenetic analyses derived from distinct datasets. However, the inner affinities of the specimen among lagerpetids are poorly resolved, the new specimen differs from Ixalerpeton polesinensis Cabreira et al., 2016 (so far the only coeval lagerpetid from Brazil) mainly in the shape of the medial condyle, which does not fold medially. Therefore, UFSM 11611 may represent a new lagerpetid taxon in the Carnian of southern Brazil, increasing the diversity and distribution of the group in this unit. Finally, the presence of a lagerpetid in the Cerro da Alemoa outcrop reveals a rich paleofauna of dinosauromorphs, so far represented by silesaurids, herrerasaurids, sauropodomorphs, and putative theropods.

\footnotetext{
*Project supported by a Fundação de Amparo à Pesquisa do Estado do Rio Grande do Sul (FAPERGS) scholarship (to M.S.G.), a Coordenação de Aperfeiçoamento de Pessoal de Nível Superior (CAPES) scholarship (to R.T.M.), and by Conselho Nacional de Desenvolvimento Científco e Tecnológico [CNPq; research grant to S.D.S, process number 306352/2016-8].
}

\section{PALEOHISTOLOGY OF A NEW NON-ARISTONECTINE ELASMOSAURID (SAUROPTERYGIA, PLE- SIOSAURIA) FROM THE CALAFATE FORMATION (UPPER CRETACEOUS), SANTA CRUZ PRO- VINCE, ARGENTINA}

\author{
J.A. Garcia Marsà̃ ${ }^{1,2}$, J.S. D'angelo ${ }^{1,2}$, M.A. Cerronil 1,2, and F.E Novas ${ }^{1,2}$
}

'Laboratorio de Anatomía Comparada y Evolución de los Vertebrados, Museo Argentino de Ciencias Naturales "Bernardino Rivadavia". Av. Ángel Gallardo 470, C1405DJR Ciudad Autónoma de Buenos Aires, Argentina. jagmdarwinista@gmail.com

${ }^{2}$ Consejo Nacional de Investigaciones Científicas y Técnicas (CONICET).

The present contribution provides an attempt to describe the microstructure and paleohistology of a large elasmosaurid specimen (MPM-PV 10004) from the Maastrichtian beds of Santa Cruz province. The thin sections examined correspond to an indeterminate diapophysis, a rib, two gastralia (lateral and medial), femur and a phalanx. The primary bone is mainly composed of a fibro-lamellar tissue. The vascularization is high, with longitudinal and reticular canals configurated as primary and secondary osteons. These features in the examined material are indicative of a rapid growth and a high metabolism. There are no sign of growth zones or annuli/LAGS in the cortical region. It is remarkably the presence of numerous Sharpey's fibers in the rib section and the medial gastralia; as well as the presence of an External Fundamental System (EFS) in those thin sections corresponding to both gastralia; which would indicate that the animal reached the somatic maturity. Interestingly, the gastralia displays osteoporotic bone 'sandwiched' between two layers of thick pachyostotic cortical tissue, especially in the medial gastralia. It is thought that pachyostosis, particularly of the ribs and other thoracic elements acts as hydrostatic ballast which increases stability. Therefore, the MPM-PV 10004 specimen is interpreted as an animal of low swimming speeds and lack of agility restricted to living in shallow water environments, in where an increased stability was advantageous. 


\title{
A COMPARATIVE HISTOLOGICAL ANALYSIS OF THE FEMORAL SHAFT OF THE CROCODYLO- MORPHS NEUQUENSUCHUS UNIVERSITAS FIORELLI AND CALVO, 2007 AND NOTOSUCHUS TERRESTRIS WOODWARD, 1896
}

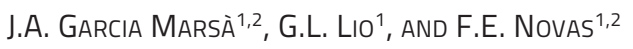 \\ 'Laboratorio de Anatomía Comparada y Evolución de los Vertebrados, Museo Argentino de Ciencias Naturales "Bernardino Rivadavia". Av. \\ Ángel Gallardo 470, C1405DJR Ciudad Autónoma de Buenos Aires, Argentina. jagmdarwinista@gmail.com \\ ${ }^{2}$ Consejo Nacional de Investigaciones Científicas y Técnicas (CONICET).
}

The record of Patagonian crocodyliforms is composed by terrestrial forms, particularly by notosuchians. Remains of the well-known crocodile Notosuchus terrestris Woodward, 1896 are very common in Upper Cretaceous outcrops of Neuquén city. Neuquensuchus universitas Fiorelli and Calvo, 2007 is a purported protosuchian, which was also found at the same locality. New remains of Neuquensuchus (MACN-Pv N28; MACN-Pv N29) were published recently as coming from the same quarry of the holotype. There were also recovered isolated appendicular materials that can be referred to Notosuchus. In the present communication we studied the bone histology of two femora, one of each taxon (Neuquensuchus, Notosuchus). At femoral mid-diaphysis, bone cortexin Neuquensuchus is made of a fibro-lamellar matrix with parallel-fibered annulus and a low amount of longitudinal vascular canals in the cortex. In Notosuchus the growth is continuous, and the cortex is formed by a fibro-lamellar matrix constituted by a high number of longitudinal and reticular vascular canals. These general histological features differ widely between these taxa, meaning a relatively slow growth and low metabolic rate for Neuquensuchus, and contrasting with the high growth and metabolic rate show by Notosuchus. In both cases, these crocodylomorphs differs from the Cenozoic notosuchian Iberosuchus Antunes, 1975 with histology characters comparable with large lizards adapted to active predation. Histologically, Neuquensuchus contrast with the cursorial Terrestrisuchus Crush, 1984, a sphenosuchia with a relatively dense vascularization. Therefore, a terrestrial habitat and cursorial abilities are not necessarily associated with a sustained.

\section{ANÁLISIS HISTOLÓGICO DE HUESOS ACTUALES Y FÓSILES DE LAGOSTOMUS MAXIMUS DES- MAREST, 1817 (RODENTIA, CHINCHILLIDAE) DE LA REGIÓN PAMPEANA}

\author{
M.C. Garrone ${ }^{1 *}$, I.A. Cerda ${ }^{2}$ y R.L. TomassinI ${ }^{1,3 *}$ \\ 'Instituto Geológico del Sur (INGEOSUR)-Consejo Nacional de Investigaciones Científicas y Tecnológicas (CONICET). Av. Alem 1253 cuerpo B' \\ $1^{\circ}$ Piso, B8000CPB Bahía Blanca, Buenos Aires, Argentina. garrone.mariana@gmail.com \\ ${ }^{2}$ Instituto de Investigación en Paleobiología y Geología (IIPG)-Consejo Nacional de Investigaciones Científicas y Tecnológicas (CONICET), \\ Universidad Nacional de Río Negro, Museo Carlos Ameghino. Belgrano 1700, Paraje Pichi Ruca (predio Marabunta) R8324CZH Cipolletti, \\ Río Negro, Argentina.nachocerda6@yahoo.com.ar \\ ${ }^{3}$ Departamento de Geología, Universidad Nacional del Sur. Av. Alem 1253 cuerpo B’ 2 Piso, B8000CPB Bahía Blanca, Buenos Aires, Argentina. \\ rodrigo.tomassini@yahoo.com.ar
}

Los trabajos de histología de mamíferos se incrementaron en los últimos años; sin embargo, es poco lo que se conoce para restos fósiles de roedores. Se evalúan aquí los cambios osteohistológicos ocurridos durante la ontogenia de individuos actuales y fósiles de Lagostomus maximus Desmarest, 1817 (vizcacha); para ello, se examinaron secciones delgadas de 23 huesos largos (fémures, húmeros y tibias) correspondientes a nueve individuos. Los fósiles proceden del Holoceno de la Región Pampeana. La determinación etaria macroscópica se realizó a partir del análisis de las estructuras y suturas presentes en los cráneos asociados. En el estadio I (neonato), la región medular incluye una capa de hueso entretejido muy vascularizada, mientras que hacia la periferia se desarrolla una capa de hueso entretejido finamente esponjoso que evidencia un aumento en la tasa de crecimiento del individuo. En el estadio II (juvenil, <1 año), el hueso cortical se compone principalmente por tejido fibrolamelar/pseudolamelar altamente vascularizado. En el estadio III (subadultos) se observa una capa externa de hueso pseudolamelar que presenta líneas de crecimiento detenido (LAGs), marcando una disminución en la tasa de crecimiento. En los estadios IV y V (adultos), la capa externa de hueso pseudolamelar se vuelve más gruesa. Las observaciones realizadas aportan información novedosa sobre las modificaciones osteohistológicas ocurridas durante la ontogenia de la vizcacha; los restos actuales y fósiles asignados a un mismo estadio ontogenético mostraron similitudes en las características histológicas. Este estudio avala la clasificación ontogenética macroscópica y constituye una herramienta útil para la determinación etaria de materiales postcraneanos aislados.

${ }^{*}$ Beca de Entrenamiento, Comisión de Investigaciones Científicas de la provincia de Buenos Aires. 


\title{
STRONG SUPPORT FOR STEGOSAURIAN AFFINITIES OF THE ARGENTINIAN DINOSAUR ISABERRYSAURA MOLLENSIS
}

\author{
J.M. Gasca ${ }^{1}$, M. Moreno-Azanza ${ }^{2}$, L. Salgado ${ }^{3}$ Y J.I. Canudo ${ }^{4 *}$ \\ ${ }^{1}$ Museo Provincial de Ciencias Naturales "Profesor Dr. Juan A. Olsacher". CONICET. Ejército Argentino y Etcheluz, Q8340 Zapala, Neuquén, \\ Argentina.jmgaska@hotmail.com \\ ${ }^{2}$ GeoBioTec, Departamento de Ciências da Terra. Faculdade de Ciências e Tecnologia, FCT, Universidade Nova de Lisboa. 2829-526 Caparica, \\ Portugal. Museu da Lourinhã.mmazanza@fct.unl.pt \\ ${ }^{3}$ Instituto de Investigación en Paleobiología y Geología (IIPG)-Consejo Nacional de Investigaciones Científicas y Tecnológicas (CONICET), \\ Universidad Nacional de Río Negro. Av. Roca 1242, R8332EXZ General Roca, Río Negro, Argentina. Isalgado@unrn.edu.ar \\ ${ }^{4}$ Grupo Aragosaurus-IUCA (http://www.aragosaurus.com), Universidad de Zaragoza. E-50009 Zaragoza, Spain. jicanudo@unizar.es
}

Isaberrysaura mollensis is an ornithischian dinosaur from the Middle Jurassic of Patagonia (Los Molles Formation, Neuquén province, Argentina) whose phylogenetic affinities has been controversial. The specimen was preserved articulated and with some of its gut content, which was identified as seeds, most of them belonging to the Cycadales group. New anatomical data and their inclusion in the phylogenetic analysis have confirmed that Isaberrysaura mollensis Salgado et al., 2017 is the first thyreophoran dinosaur for the Jurassic of South America apart from Laquintasaura (which has also been identified as a thyreophoran in some recent phylogenetic analyses). To assess its phylogenetic position, the scores of Isaberrysaura were updated in the 'Han et al., 2017' dataset on the basis of the newly identified anatomical features. Our result contradicts the original phylogenetic placement of Isaberrysaura as a neornithischian and provides strong evidence of its thyreophoran affinities. Nevertheless, the sister-taxon relationship between Huayangosaurus and Isaberrysaura previously published is not supported in the current analysis. Furthermore, Isaberrysaura is the most basal known member of Stegosauria, representing an unusual morphotype clearly differentiated from all other stegosaurs by a broad set of synapomorphies. Stegosauria is a clade of armoured ornithischian dinosaurs temporally limited from the Middle Jurassic to the Early Cretaceous. The presence of stegosaurs during the Middle Jurassic in South America, along with their previously known occurrences in Europe and Asia, show that this thyreophoran clade already had a global distribution prior to its northern Late Jurassic diversification.

*Supported by the Spanish Ministerio de Economía y Competitividad (project CGL2017-85038-P) and the European Regional Development Fund.

\section{ESTUDIO PRELIMINAR DEL PATRÓN DE CRECIMIENTO EN SALTASAURINAE (SAUROPODA, TITANOSAURIA), DEDUCIDOS A TRAVÉS DE LA MICROESTRUCTURA ÓSEA DE HUESOS APEN-' DICULARES}

\section{R. GonZALEZ ${ }^{1 *}$}

${ }^{1}$ Centro de Ecología Aplicada del Litoral (CECOAL)-Consejo Nacional de Investigaciones Científicas y Tecnológicas (CONICET). Ruta 5, Km 2,5, 3400 Corrientes, Argentina. romigonz195@gmail.com

Saltasaurinae es un clado derivado de titanosaurios registrados en el Cretácico Superior de Argentina y representado al menos por tres especies: Neuquensaurus australis (Lydekker, 1893) Saltasaurus loricatus Bonaparte y Powell, 1980 y Rocasaurus muniozi Salgado y Azpilicueta, 2000. El clado se caracteriza por el modesto tamaño ( 9 m longitud) que alcanzaron con respecto al resto de los Titanosauria. Recientemente, se ha reportado que la histología de huesos largos de titanosaurios derivados y de talla reducida (Ampelosaurus atacis Le Loeuff, 1995 y Magyarosaurus dacus Nopsca, 1915) exhiben un tejido laminar modificado (MLB), el cual se relaciona con una tasa de crecimiento inferior a la estimada en otros neosauropodos. En este trabajo se propone evaluar la presencia de MLB en fémures de saltasaurinos: N. australis (MCS-Pv 5/27), R. muniozi (MPCA-Pv 46/6) y S. loricatus (PVL 4017-82). Con fines comparativos se incluyó también un fémur asignado a Aeolosaurus rionegrinus Powell, 1987 (MPCA-Pv 27177), procedente del Cretácico Superior de Patagonia cuya talla supera a la de los saltasaurinos. Tanto $N$. autralis como S. loricatus exhibieron MLB, pero no así R. muniozi ni A. rionegrinus, para los cuales se reportó un típico tejido fibrolamelar. Dado que el ejemplar estudiado de $R$. muniozi corresponde a un subadulto de tamaño equivalente al de los adultos de $N$. australis y S. loricatus, se infiere que el MLB podría estar efectivamente vinculado a la talla reducida (y por ende a una tasa de crecimiento baja) de algunos titanosaurios, pero que este no sería un carácter común a todos los saltasaurinos.

\footnotetext{
*Proyecto subsidiado por PICT 2015-1021 y Jurassic Foundation.
} 


\title{
HISTOLOGÍA ÓSEA DE PELLEGRINISAURUS POWELLI SALGADO, 1996 (SAUROPODA, TITANO- SAURIA) DEL CRETÁCICO SUPERIOR DEL NORTE DE PATAGONIA
}

\author{
R. GonzálezZ1 I.A. Cerda², V.L. ZurRiaguz ${ }^{3}$ Y L. Salgado ${ }^{3 *}$ \\ 'Centro de Ecología Aplicada del Litoral (CECOAL)-Consejo Nacional de Investigaciones Científicas y Tecnológicas (CONICET). Ruta 5, Km 2,5, \\ 3400 Corrientes, Argentina. romigonz195@gmail.com \\ ${ }^{2}$ Instituto de Investigaciones en Paleobiología y Geología (IIGP)-Consejo Nacional de Investigaciones Científicas y Tecnológicas CONICET, \\ Universidad Nacional de Río Negro. Museo Provincial Carlos Ameghino, Belgrano 1700, Paraje Pichi Ruca (predio Marabunta), CP8300 Ci- \\ polletti, Río Negro, Argentina.nachocerda6@yahoo.com.ar \\ ${ }^{3}$ Instituto de Investigaciones en Paleobiología y Geología (IIGP)-Consejo Nacional de Investigaciones Científicas y Tecnológicas (CONICET), \\ Universidad Nacional de Río Negro. Av. Julio A. Roca 1242, R8332EXZ General Roca, Río Negro.vzurriaguz@gmail.com; Isalgado@unrn.edu.ar
}

Los estudios paleohistológicos han demostrado ser una valiosa herramienta para inferir cuestiones acerca de la biología de organismos extintos, en particular, en grupos que carecen de análogos modernos como es el caso de los dinosaurios saurópodos. En el marco de un estudio de redescripción del taxón, se examinó la osteohistología de un fémur izquierdo perteneciente al holotipo del titanosaurio Pellegrinisaurus powelli Salgado, 1996 (MPCA-Pv 1500). El principal objetivo del estudio es establecer el estadio ontogenético del individuo. El material proviene del margen sur del Lago Pellegrini, provincia de Río Negro (Formación Allen, Campaniano-Maastrichtiano inferior). Se efectuaron cuatro secciones delgadas al nivel de la diáfisis. Las cortezas interna y media están conformadas mayormente por un tejido haversiano denso. En la corteza externa se observó tejido primario de tipo "laminar modificado" (i.e., matriz pseudolamelar con osteonas primarias organizadas en láminas). En la corteza posterior externa se detectó una hilera de amplias cavidades de reabsorción revestidas internamente por una delgada capa de tejido lamelar. Se reconocieron al menos cuatro líneas de crecimiento detenido (LAGs). No se pudo reconocer un sistema fundamental externo. La ausencia de esta última estructura indica que, pese al completo estado de fusión de las suturas neurocentrales de las vértebras caudales, el individuo se encontraba en pleno crecimiento al momento de morir. No obstante, la poca distancia entre LAGs sugiere que se trata de un individuo sexualmente maduro. Las amplias cavidades observadas en la corteza externa no han sido reportadas en otros saurópodos, siendo su origen incierto hasta el momento.

*Proyecto subsidiado por PICT 2015-1021 y Jurassic Foundation.

\section{HALLAZGO DE MADRIGUERA DE TAMAÑO EXCEPCIONAL EN EL ÁREA PALEONTOLÓGICA DE LA BUITRERA, EN LA FORMACIÓN CANDELEROS (CENOMANIANO), LOCALIDAD DE CERRO POLICÍA, RÍO NEGRO}

\author{
M.S. Gualde ${ }^{1}$, J. Kaluza², M.L. Sánchez Y y. Apesteguía $2,3 *$ \\ 'Departamento de Geología, Universidad Nacional de Río Cuarto. Ruta Nac. 36, Km 601, X5804BYA Río Cuarto, Argentina. \\ msoledadgualde@gmail.com; msanchez@exa.unrc.edu.ar \\ 2'Área de Paleontología, Fundación de Historia Natural "Félix de Azara", Centro de Estudios Biomédicos, Biotecnológicos Ambientales y Diag- \\ nóstico (CEBBAD)-Universidad Maimónides. Hidalgo 775, C1405CBK Ciudad Autónoma de Buenos Aires, Argentina. yojonatan@hotmail.com; \\ sebapesteguia@gmail.com \\ ${ }^{3}$ Consejo Nacional de Investigaciones Científicas y Tecnológicas (CONICET).
}

La búsqueda de fósiles del Cretácico Superior en la Formación Candeleros (Cenomaniano), en el área paleontológica de La Buitrera, ha permitido el hallazgo de una traza fósil de dimensiones significativas, ubicada en depósitos de desbordes en una planicie de inundación fluvial. La traza corresponde a una estructura tubular en forma de galerías, de al menos $3 \mathrm{~m}$ de largo, $30 \mathrm{~cm}$ de ancho y $8 \mathrm{~cm}$ de alto en corte transversal, dispuesta paralela a la superficie estratal. Las galerías se bifurcan y conservan el diámetro a lo largo de su extensión. A través de la morfología de la traza, se la interpreta como una madriguera o paleocueva. La extensión de la misma revela que se trata de una mega-estructura. Existe también cierta correspondencia entre las dimensiones de la excavación y los vertebrados pequeños a medianos registrados en el área. Dadas las características de la región, asociadas al desarrollo de un paleodesierto, los organismos productores podrían haber utilizado este tipo de recurso habitacional para reproducción o refugio durante estaciones o climas extremos, al igual que sucede con los vertebrados excavadores modernos. Por otra parte, los hábitos de excavación amplían el rango conocido de comportamientos para los organismos hallados en La Buitrera hasta el momento.

*Proyecto subsidiado por MinCyT PICT 2014-0564 "Biota y ambientes cretácicos del área paleontológica de La Buitrera (Cerro Policía, Río Negro)" Director: Dr. Sebastián Apesteguía. 


\title{
RECOGNITION OF LOGICAL CORRELATION IN CHARACTERS BASED ON RATIOS USED IN PHY- LOGENETIC ANALYSES
}

\author{
J.A. Haro ${ }^{1,2,3}$, G.L. Nieto ${ }^{1,2,3}$, A.A. Tauber ${ }^{1,2,4}$, J.M. Krapovickas ${ }^{1,2,4}$, R.D. JuÁrez Valieri ${ }^{5,6}$, M. Fabianelli ${ }^{1}$ y F. Rosas $^{1}$ \\ ${ }^{1}$ Museo de Paleontología, Facultad de Ciencias Exactas, Físicas y Naturales, Universidad Nacional de Córdoba, Vélez Sarsfield 249, X5000JJC \\ Córdoba, Provincia de Córdoba, Argentina.maxifabianelli@gmail.com; federosas24@gmail.com \\ Cátedra de Paleontología, Facultad de Ciencias Exactas, Físicas y Naturales, Universidad Nacional de Córdoba. Vélez Sarsfield 1611, X5016GCA \\ Córdoba, Provincia de Córdoba, Argentina. adantauber@gmail.com \\ ${ }^{3}$ Consejo Nacional de Investigaciones Científicas y Técnicas (CONICET).augustoharo@gmail.com; gastonleonardonieto@gmail.com \\ ${ }^{4}$ Museo Provincial de Ciencias Naturales "Dr. Arturo Umberto Illía". Poeta Lugones 395, X5000HZD Córdoba, Provincia de Córdoba, Argentina. \\ jerokrapo@yahoo.com.ar \\ ${ }^{5}$ Museo Provincial Carlos Ameghino. Belgrano 1700, Paraje Pichi Ruca (predio Marabunta), R8324CZH Cipolletti, Río Negro, Argentina. \\ rubendjuarez@gmail.com \\ ${ }^{6}$ Dirección de Patrimonio y Museos, Secretaría de Cultura de la Provincia de Río Negro. General Roca, Río Negro, Argentina.
}

Some characters used in phylogenetic inference correspond to ratios sharing a measurement. Their joint use in analyses may allow a single variation in the shared measurement to imply character state variation in the ratios calculated based on such measurement. Such ratio characters would be non-independent. However, measurement sharing between ratios does not necessarily imply correlation. The reason is a ratio value associated with a character state variation may alternatively derive from variation in the non-shared measurement. A method to test hypotheses of logical correlation by variation in the shared measurement involves pairwise ratio comparison. This allows recognizing coincidence/difference in the groups suggested by two ratios. Ratios suggesting different groups indicate the variation in the shared measurement suggesting a group in a ratio is not the same variation suggesting the group in the other ratio, implying independence. If the groups coincide, comparison of the pattern of variation for both ratios is crucial. For example, if the shared measurement is in one ratio on the numerator and in the other in the denominator, correlation requires one of the suggested compared groups to associate with a larger ratio value and the other to a lower one. Additive multistate ratio characters suggest more than one group, and thus may share some groups but not others. If the shared groups present some corresponding variation, logical correlation is unrefuted just for those variations, but not necessarily the entire character. Analytically equivalent representation of additive multistate characters in binary form may help singly discarding possibly correlated transformations.

\section{LAS HUELLAS DE DINOSAURIOS COMO EVIDENCIA DE EXPOSICIÓN SUBAÉREA DEL MIEMBRO PILMATUÉ DE LA FORMACIÓN AGRIO (CRETÁCICO INFERIOR) DE LA CUENCA NEUQUINA}

\author{
A.M. Heredia ${ }^{1}$, P.J. Pazos ${ }^{1}$, D.E. Fernández ${ }^{1}$ y M. Comerio ${ }^{2 *}$ \\ ${ }^{1}$ Instituto de Estudios Andinos "Don Pablo Groeber" (IDEAN), Universidad de Buenos Aires-Consejo Nacional de Investigaciones Científicas y \\ Tecnológicas (CONICET). Intendente Güiraldes 2160, Ciudad Universitaria-Pabellón II, C1428EGA Ciudad Autónoma de Buenos Aires, Argentina. \\ heredia@gl.fcen.uba.ar; pazos@gl.fcen.uba.ar; elizabeth@gl.fcen.uba.ar \\ ${ }^{2}$ Centro de Tecnología de Recursos Minerales y Cerámica (CETMIC)-CONICET. Camino Centenario y 506, 1897 M.B. Gonnet, La Plata, Argentina. \\ marcoscomerio@gmail.com
}

Se reporta el primer hallazgo de huellas de dinosaurios en depósitos marinos del Miembro Pilmatué (Valanginiano superior-Hauteriviano inferior) de la Formación Agrio de la cuenca Neuquina. Las mismas están expuestas en la sección media a superior de la unidad, en dos superficies de pisoteo (trampling) caracterizadas por un índice de dinoturbación moderado. Dichas huellas están preservadas en epirelieve negativo en un nivel de areniscas calcáreas y bioclásticas con óndulas simétricas indicadoras de oleaje. El nivel suprayacente se caracteriza por presentar alta concentración de componentes bioclásticos milimétricos muy fragmentados y escasa participación de oolitas, lo que apunta a condiciones de energía modera a alta en un rango batimétrico por encima del nivel de base de olas de buen tiempo y aguas templadas. Las huellas son relativamente profundas, muestran rasgos de erosión diferencial y un bajo grado de preservación por lo que no pudieron ser asignadas a un icnotaxón en particular. En la superficie de pisoteo se identificó claramente al menos una rastrillada, con hueIlas de contorno subredondeado, más largas que anchas, algunas con marcas de dígitos pobremente impresas. Estas huellas representan la primera evidencia de exposición subaérea documentada en la unidad y en sectores distales de la cuenca y, asimismo constituyen uno de los registros más antiguos de huellas cretácicas en la cuenca Neuquina.

*Esta es una contribución C-146 del Instituto de Estudios Andinos "Don Pablo Groeber"/ Proyecto subsidiado por PIP CONICET 2015-2017 y UBACyT 2016-2018 


\title{
NUEVAS EVIDENCIAS MICROANATÓMICAS (CUALITATIVAS Y CUANTITATIVAS) SOBRE LA PALEOECOLOGIIA DEL CAPARAZÓN DE LAS TORTUGAS FÓSILES Y ACTUALES
}

\author{
J.M. Jannello ${ }^{1}$, I.A. Cerda ${ }^{2}$ y M.S. De La Fuente ${ }^{1 *}$ \\ ${ }^{1}$ Grupo vinculado al Instituto Argentino de Nivología y Glaciología, Centro Científico Tecnológico-Mendoza, Concejo Nacional de Investigacio- \\ nes Científicas y Tecnológicas (CONICET), Museo de Historia Natural de San Rafael. Av. Ballofet s/n, 5600 San Rafael, Mendoza, Argentina. \\ marcosjannello@hotmail.com \\ ${ }^{2}$ Instituto de Investigaciones en Paleobiología y Geología (IIPG)-Consejo Nacional de Investigaciones Científicas y Tecnológicas (CONICET), \\ Universidad Nacional de Río Negro, Museo Provincial Carlos Ameghino. Belgrano 1700, Paraje Pichi Ruca (predio Marabunta), R8324CZH \\ Cipolletti, Río Negro, Argentina.nachocerda6@yahoo.com.ar
}

Recientemente se ha comenzado a emplear a las características microanatómicas del caparazón de los Testudinata para realizar inferencias con respecto a su hábitat. En particular, se ha establecido que placas altamente porosas (índices de compactación $[C] \geq 0,8$ ) estarían vinculadas a ambientes acuáticos marinos, de porosidad muy reducida $(C \leq 0,6)$ a ambientes terrestres y de porosidad intermedia a ambientes acuáticos dulceacuícolas. Con el objeto de poner a prueba esta hipótesis, se efectuó un estudio osteohistológico del caparazón de diversos taxa de Testudinata, tanto actuales como fósiles, de hábitos conocidos. El muestreo incluyó 14 taxa tanto de tortugas fósiles basales (e.g., Patagoniaemys gasparinae Sterli y de la Fuente, 2011) como también tortugas actuales (e.g., Chelonia mydas [L. 1758]). También se tuvieron en cuenta para este estudio diferentes elementos del caparazón tales como placas costales, periféricas y otras placas del plastrón. Los índices de compactación de las muestras fueron obtenidos mediante el programa Bone Profiler. Si bien en algunos casos los valores obtenidos fueron congruentes con el hábitat (e.g., Hydromedusa casamayorensis de la Fuente y Bona, 2002, C= 0,72), esto no ocurrió en todos los taxa examinados. Por ejemplo, se reportó una compactación elevada en especies acuáticas marinas (e.g., Chelonia mydas, C=0,85) y acuáticas continentales (e.g., Prochelidella cerrobarcinae de la Fuente et al., 2001, C=0,83). También se registró una compactación reducida en especies terrestres (e.g., Chelonoidis gringorum Simpson, 1942, C=0,69). Estos resultados revelan que no existe una correlación directa entre el hábitat y la microanatomía del caparazón de los Testudinata.

*Proyecto subsidiado por Agencia PICT 2013-0095 M.S de la Fuente.

\section{MORPHOLOGICAL AND PHYLOGENETIC IMPLICANCES OF THE PROCESSES OF OPHISTO- COELIZATION AND PROCOELIZATION ON THE SACROCAUDAL AXIAL SKELETAL SEQUENCE OF THE TITANOSAUR SAUROPODS}

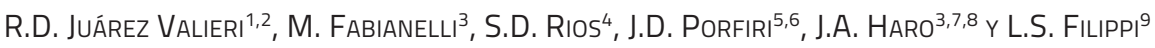

\begin{abstract}
${ }^{1}$ Museo Provincial Carlos Ameghino. Belgrano 1700, Paraje Pichi Ruca (predio Marabunta), R8324CZH, Cipolletti, Río Negro, Argentina. rubendjuarez@gmail.com

${ }^{2}$ Dirección de Patrimonio y Museos, Secretaría de Cultura de la Provincia de Río Negro. General Roca, Río Negro, Argentina.

${ }^{3}$ Museo de Paleontología, Facultad de Ciencias Exactas, Físicas y Naturales, Universidad Nacional de Córdoba. Vélez Sarsfield 249, X5000JJC Córdoba, Provincia de Córdoba, Argentina. maxifabianelli@gmail.com

4Departamento de Arqueología y Paleontología. Secretaría Nacional de Cultura. Asunción, Paraguay. sergiord40@gmail.com

${ }^{5}$ Museo de Ciencias Naturales, Universidad Nacional del Comahue. Buenos Aires 1400, Q8300IBX Neuquén, Argentina.jporfiri@gmail.com

${ }^{6}$ Cátedra Reptiles Mesozoicos, Facultad de Ingeniería, Universidad Nacional del Comahue. Buenos Aires 1400, Q8300IBX Neuquén, Argentina. ${ }^{7}$ Cátedra de Paleontología, Facultad de Ciencias Exactas, Físicas y Naturales, Universidad Nacional de Córdoba. Vélez Sarsfield 1611, X5016GCA Córdoba, Provincia de Córdoba, Argentina. augustoharo@gmail.com

${ }^{8}$ Consejo Nacional de Investigaciones Científicas y Técnicas (CONICET).

9Museo Municipal "Argentino Urquiza". Rincón y Chaco s/n, Q8319BFA Rincón de los Sauces, Neuquén, Argentina. Isfilippi@gmail.com
\end{abstract}

The variation on the axial sequence among sauropod dinosaurs can be considered as the rosetta stone for the understanding of their relationships. Several changes regarding pneumaticity, laminar structure and centrum morphology, have been hypothesized as results of a size increment. Most of the axial characters have been only shown as changes along the phylogeny of the group, despite some features look erratic or are poorly understood. A peculiar case is the morphological disparity among sacral and caudal centra within Titanosauria. The presence of amphiplatyan, procoelous, ophistocoelous, and biconvex centra has not proved yet to follow a consecutive order, and their implementation in cladistic analyses results in multiple appearance and reversal events. Here, we review multiple titanosaur taxa and close relatives preserving sacrocaudal sequences, restructuring the character definitions applied to different recent phylogenetic hypotheses, and re-analized these datasets. We interpret, then, the variation in centrum morphology as the result of two independent processes. First, a process of opisthocoelization of the axial sequence, already well known for presacral elements in Sauropoda, which in titanosaurs intrudes to the sacrum to finally reach the tail. Second, a procoelization progressive event which evolved inde- 
pendently in several eusauropod lineages. In Titanosauria, the latter originates posterior to the first sacral elements to progressively dominate the caudal series. The eventual overlap of both processes resulted in a variety of morphologies that can be interpreted as an ordered sequence of biconvex elements placed originally in the sacrum. This model fits with the widely accepted phylogenetic relationships for Titanosauria.

\title{
PATOLOGÍAS ÓSEAS EN TOXODON PLATENSIS OWEN, 1837 (NOTOUNGULATA, TOXODONTIDAE) DE LA PROVINCIA DE CORRIENTES, ARGENTINA
}

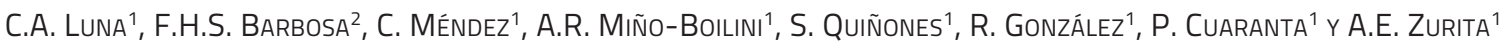 \\ ${ }^{1}$ Centro de Ecología Aplicada del Litoral (CECOAL)-Consejo Nacional de Investigaciones Científicas y Tecnológicas (CONICET). Ruta 5, km 2,5, \\ 3400 Corrientes, Argentina. carlosaluna@hotmail.com \\ ${ }^{2}$ Programa de Pós-Graduação em Análise de Bacias e Faixas Móveis, Universidade do Estado do Rio de Janeiro (UERJ). Rua São Francisco \\ Xavier, 524, 20550-103 Maracaña, Rio de Janeiro, Brazil.
}

En los últimos años, los estudios sobre paleopatologías en mamíferos fósiles del Pleistoceno de Sudamérica se han incrementado considerablemente, fundamentalmente en los Xenarthra. Sin embargo, en algunos grupos como los Notoungulata, el conocimiento del desarrollo de estas afecciones se encuentra poco desarrollado. En la presente comunicación se analizan distintas patologías óseas en ejemplares de Toxodon platensis Owen, uno de los taxones más frecuentes de las asociaciones cuaternarias de la provincia de Corrientes, Argentina. Los materiales analizados se encuentran depositados en la Colección Paleontológica "Rafael Herbst" (FaCENA, UNNE) y proceden de niveles asignados a la Formación Toropí/ Yupoí (Pleistoceno Tardío) expuestos en los Arroyos Riachuelo y Santa Lucía. Mediante un análisis macroscópico se detectaron las siguientes alteraciones patológicas: en el ejemplar CTES-PZ 1564 algunos de los dientes presentan una leve hipoplasia de esmalte caracterizada por múltiples ranuras mesiodistales; en el Metacarpal III se observa un proceso de erosión ósea compatible con osteocondritis disecante (una necrosis avascular); y en las vértebras dorsales y caudales se observan indicios de nódulos o hernia de Schmorl y espondiloartropatía. En tanto el ejemplar CTES-PZ 7791 muestra una evidente cloaca (canal de drenaje de pus) en el Metatarsal IV indicativo de una osteomielitis, denotando un proceso infeccioso crónico. Si bien algunas de estas patologías han sido previamente mencionadas para el género, otras constituyen los primeros registros en notoungulados y aportan nuevos datos para el análisis del desarrollo de estas afecciones en los grandes mamíferos del Cuaternario de Sudamérica.

\section{IMPLICANCIAS EN LAS MODIFICACIONES DEL HUESO CORACOIDES EN TERÓPODOS PARAVIANOS}

\author{
G.E. Lo Coco ${ }^{1}$, M.J. Motta ${ }^{1}$, F.L. Agnolín ${ }^{1,2}$, F. Brissón Egli ${ }^{1}$ y F.E. Novas ${ }^{1}$
}

\begin{abstract}
${ }^{1}$ Laboratorio de Anatomía Comparada y Evolución de los Vertebrados, Museo Argentino de Ciencias Naturales "Bernardino Rivadavia"Consejo Nacional de Investigaciones Científicas y Tecnológicas (CONICET). Av. Ángel Gallardo 470, C1405DJR Ciudad Autónoma de Buenos Aires,Argentina.gastonlococo@gmail.com; matiasjmotta@gmail.com; fedebe@gmail.com; fernovas@yahoo.com.ar

${ }^{2}$ Fundación de Historia Natural "Félix de Azara", Departamento de Ciencias Naturales y Antropología, Centro de Estudios Biomédicos, Biotecnológicos, Ambientales y Diagnóstico (CEBBAD)-Universidad Maimónides. Hidalgo 775, Piso 7, C1405BDB Ciudad Autónoma de Buenos Aires, Argentina.fedeagnolin@yahoo.com.ar
\end{abstract}

En aves voladoras actuales el músculo supracoracoides recorre hacia arriba la cara anteromedial del coracoides, rodea al proceso acrocoracoidal y atraviesa el foramen trióseo para finalmente insertarse sobre la cara dorsal del húmero. Su función es clave en la elevación del ala y la rotación longitudinal del húmero. John Ostrom describió la condición presente en Archaeopteryx Meyer 1861, remarcando que el tubérculo bíceps (homólogo del proceso acrocoracoidal) es pequeño y carece de la proyección anterodorsal característica de las neognatas. Ostrom concluyó que el músculo supracoracoides de Archaeopteryx no cumplía una función elevadora del húmero, sino una protractora. Sin embargo, la comparación entre paravianos basales (e.g., Buitreraptor gonzalezorum Makovicky et al., 2005) y neognatos voladores actuales (e.g., Vultur gryphus Linnaeus, 1758) revela que comparten un canal que encausa el recorrido del músculo supracoracoides en la cara anterior del coracoides, y que la diferente orientación y desarrollo del tubérculo bíceps en unos y otros no afecta el recorrido del tendón del supracoracoides. A diferencia de Ostrom, creemos que el cambio de acción del músculo supracoracoides de protractor (en paravianos basales) a elevador (en aves voladoras vivientes), radica en la orientación de la cavidad glenoides, con eje mayor subvertical en paravianos basales y horizontal en neognatas. Así, el gran desarrollo del proceso acrocoracoidal en neognatas se vincularía con el desarrollo del ligamento acrocoracohumeral (ya visibilizado por David Baier y colegas en 2007), así como la fuerza ejercida por los músculos bíceps brachii y coracobrachialis anterior en la fase descendente del aleteo. 


\title{
TRAZAS DE BIOEROSIÓN SOBRE RESTOS DE MAMÍFEROS DEL PLEISTOCENO TARDÍO-HOLO- CENO TEMPRANO DEL NORTE DE ARGENTINA
}

\author{
C. Méndez ${ }^{1}$, C.A. Luna ${ }^{1}$, R.L. Tomassini ${ }^{2}$, C.I. Montalvo ${ }^{3}$, A. Zurita ${ }^{1}$ y J. Friedrichs ${ }^{4}$
}

1Departamento de Biología, Facultad de Ciencias Exactas, Naturales y Agrimensura, Universidad Nacional del Nordeste, Centro de Ecología Aplicada del Litoral (CECOAL)-Consejo Nacional de Investigaciones Científicas y Tecnológicas (CONICET). Ruta 5, km 2,5, 3400 Corrientes, Argentina. 2Departamento de Geología, Universidad Nacional del Sur, Instituto Geológico del Sur (INGEOSUR)-Consejo Nacional de Investigaciones Científicas y Tecnológicas (CONICET). Av. Alem 1253 cuerpo B' $1^{\circ}$ Piso, B8000CPB Bahía Blanca, Buenos Aires, Argentina.

${ }^{3}$ Facultad de Ciencias Exactas y Naturales, Universidad Nacional de La Pampa. Avda. Uruguay 151, L6300CLB Santa Rosa, La Pampa, Argentina. ${ }^{4}$ Museo Provincial de Ciencias Naturales. Avenida Sarmiento s/n, 3526 Villa Escolar, Formosa, Argentina.

Las trazas de bioerosión aportan información importante en los análisis paleoambientales y paleoecológicos, como así también en la reconstrucción de las historias tafonómicas. En esta contribución se dan a conocer registros de trazas asignadas a insectos necrófagos producidas sobre restos de vertebrados recuperados de depósitos de la Formación Río Bermejo (Pleistoceno Tardío-Holoceno Temprano, provincia de Formosa), interpretados como depósitos de pantano que reIlenaron paleocanales del antiguo Río Bermejo. Estas marcas fueron identificadas en un cráneo y una mandíbula asignados a Pampatherium sp. Gervais y Ameghino, 1880 (PVE-F37) y en varios fragmentos de corazas asignadas a Neosclerocalyptus sp. Paula Couto, 1957 (PVE-F20, 39, 69, 96). Las trazas consisten en perforaciones con secciones subcirculares a ovoides, rectas o ligeramente sinuosas. De acuerdo al diámetro máximo pueden dividirse en dos grupos, uno de 4,5 mm y otro de 9 mm promedio. En los osteodermos algunas de las perforaciones atraviesan todo su espesor, mientras que otras son más superficiales. Muchas de las perforaciones están rellenas de sedimento, similar al de los niveles portadores, lo que sugiere que las trazas se produjeron con anterioridad al enterramiento de los huesos. La morfología y el tamaño de las perforaciones registradas coinciden con los de trazas asignadas a cámaras pupales originadas por coleópteros derméstidos, incluidas en la categoría etológica Pupichnia. Estas trazas son características de ambientes continentales, por lo tanto su registro es coherente con las interpretaciones paleoambientales propuestas para los niveles fosilíferos.

\section{PRIMER REGISTRO DE LEOPARDUS GRAY (CARNIVORA, FELIDAE) EN EL PLEISTOCENO TARDÍO DE LA PROVINCIA DE CORRIENTES}

\author{
C. Méndez ${ }^{1}$, A.E. Zurita ${ }^{1}$, S. Contreras ${ }^{1}$, C.A. Luna ${ }^{1}$, P. Cuaranta ${ }^{1}$, A.R. Miño-Boilini ${ }^{1}$ y F. Prevosti ${ }^{2 *}$
}

${ }^{1}$ Centro de Ecología Aplicada del Litoral (CECOAL)-Consejo Nacional de Investigaciones Científicas y Tecnológicas (CONICET) y Universidad Nacional del Nordeste. Ruta 5, km 2,5, 3400 Corrientes, Argentina

${ }^{2}$ Centro Regional de Investigaciones Científicas y Transferencia Tecnológica de La Rioja (CRILAR)-Universidad Nacional de La Rioja-Servicio Geológico Minero Argentino (SEGEMAR)-Universidad Nacional de Catamarca-Consejo Nacional de Investigaciones Científicas y Tecnológicas (CONICET). Entre Ríos y Mendoza s/n, 5301 Anillaco, La Rioja, Argentina.

La Formación Toropí/Yupoí (ca. 5238 ka., Pleistoceno Tardío) es una de las unidades fosilíferas más ampliamente distribuida en la provincia de Corrientes (Argentina), conteniendo una importante diversidad de vertebrados con más de 40 taxones reconocidos, dentro de los cuales predominan ampliamente los mamíferos herbívoros sobre un escaso registro de carnívoros. En particular, estos últimos se encuentran limitados a materiales pobremente preservados correspondientes a dos Felidae (Panthera onca (Linnaeus, 1758) y Smilodon populator Lund, 1842) y un Canidae indeterminado. Recientes trabajos de prospección han dado como resultado el hallazgo en el miembro inferior de esta unidad de una hemimandíbula derecha con la serie p3-m1 y un fragmento de maxilar izquierdo con P4-M1, los cuales se interpretan como correspondientes al mismo ejemplar (CTES PZ-7780). El tamaño de la mandíbula se encuentra dentro del rango de variación de Leopardus Gray, 1842, siendo considerablemente menor que otros géneros como Puma Linnaeus, 1771 y Panthera Linnaeus, 1758. En tanto, la morfología dentaria y de la mandíbula también remite a este género, difiriendo de otros géneros como Herpailurus en que la rama horizontal tiene una altura uniforme y es robusta en su extremo anterior. Las especies de este género se encuentran adaptadas a diferentes hábitats, que van desde la Cordillera de los Andes hasta las sabanas húmedas del Pantanal en Brasil. En síntesis, este representa el primer registro para el Pleistoceno Tardío de la región Mesopotámica de Argentina.

*Proyecto subsidiado por PIQ002/17. 


\title{
APPLICATION OF THE MULTIPLE IMPUTATIONS METHOD IN THE MORPHOMETRIC STUDY OF THEROPOD TEETH
}

\author{
J.G. Meso ${ }^{1,2}$, M.A. Baiano ${ }^{1,3}$, F. Archuby ${ }^{1,2}$, J.I. Canale ${ }^{1,4}$, And L. Salgado ${ }^{1,2}$ \\ ${ }^{1}$ Consejo Nacional de Investigaciones Científicas y Técnicas (CONICET). \\ Instituto de Investigación en Paleobiología y Geología (IIPG)-Consejo Nacional de Investigaciones Científicas y Tecnológicas (CONICET), Uni- \\ versidad Nacional de Río Negro. Av. Roca 1242, R8332EXZ Gral. Roca, Río Negro, Argentina. jgmeso@unrn.edu.ar \\ ${ }^{3}$ Museo "Carmen Funes". Av. Córdoba 55, Q8318EBA Plaza Huincul, Neuquén, Argentina. \\ "4́rea Laboratorio e Investigación, Museo Paleontológico "Ernesto Bachmann". 8311 Villa El Chocón, Neuquén, Argentina.
}

From the pioneering work of Currie and collaborators at the beginning of the 90's, a large number of qualitative and quantitative parameters began to be established and systematized, with the aim of achieving a more precise classification of isolated theropod teeth. Due to exposure of these materials to taphonomic processes, the missing data are relatively common in the study of these elements. Such loss of information can lead to a drastic reduction of the original dataset, and therefore to biased conclusions. Currently, few statistical programs are available that allow the direct use of incomplete data sets to perform different multivariate methods, but all of them show a low statistical power. The objective of this work is to evaluate the quality of a database obtained after the application of the multiple imputation method to recover lost data. The most common approaches to deal with missing data have different consequences on the dataset and hence on the results of the analysis. "Casewise/variable deletion" consists on removing the specimens or variables that have missing values. In "Mean value imputation" missing values are replaced by their column average, resulting in a reduction of variation and an artificial increase in the power of tests. In the method of "Iterative imputation", missing values are initially replaced by their column average. An initial PCA run is then used to compute regression values for the missing data. The procedure is iterated until convergence. The results obtained suggest this method provides a better resolution for the identification of isolated teeth.

\section{NEW INFORMATION ON THE SKULL OF PATAGONYKUS PUERTAI (THEROPODA, ALVAREZ- SAURIDAE)}

\author{
J.G. Meso ${ }^{1,2}$, M.A. Baiano ${ }^{1,3}$, J.I. Canale ${ }^{1,4}$, R.A. Coria ${ }^{1,3}$, and L. Salgado ${ }^{1,2}$ \\ ${ }^{1}$ Consejo Nacional de Investigaciones Científicas y Técnicas (CONICET). \\ Instituto de Investigación en Paleobiología y Geología (IIPG)-Consejo Nacional de Investigaciones Científicas y Tecnológicas (CONICET), \\ Universidad Nacional de Río Negro. Av. Roca 1242, R8332EXZ Gral. Roca, Río Negro, Argentina. jgmeso@unrn.edu.ar \\ ${ }^{3}$ Museo "Carmen Funes". Av. Córdoba 55, Q8318EBA Plaza Huincul, Neuquén, Argentina. \\ "Área Laboratorio e Investigación, Museo Paleontológico "Ernesto Bachmann". 8311 Villa El Chocón, Neuquén, Argentina.
}

The small coelurosaur theropod Patagonykus puertai (PVPH-37), recovered in Portezuelo Formation (Turonian-Coniacian, Upper (retaceous), from Neuquén province, Argentina, was originally published as represented by postcranial elements of a single individual. A recent review of the holotype specimen has revealed the presence of several cranial remains that include: both frontals articulated and attached to the right prefrontal, a possible fragment of the right nasal, a fragment of the left squamosal articulated with a distal fragment of the postorbital, and a fragment of the left dentary. Frontals are longer than wide, with a simple interfrontal suture, lacking the complex interdigitation observed in Shuvuuia. In the anterior end, the frontal shows a short and transversal contact with the nasal, similar to the condition present in Haplocheirus. Anterolaterally, the frontal has a long contact with the prefrontal, as observed in Shuvuuia. The squamosal is triangular, presumably with the plane facing dorsolaterally and ventromedially as in Shuvuuia. The anterior projection is compressed anteromedially to dorsolaterally, and contacts the postorbital through a sigmoid suture. Anteroventrally, the quadratojugal process is short and robust resembling Shuvuuia, but dorsoventrally flat as in Haplocheirus. The dentary is dorsoventrally low and lateromedially wide, as in Haplocheirus. The new cranial information could improve the internal phylogenetic relationship of the clade, especially between the Patagonykinae and the other internal taxa of Alvarezsauridae. 


\title{
ANOMALÍAS DENTARIAS Y ÓSEAS EN CATONYX TARIJENSIS (GERVAIS Y AMEGHINO) (XENARTHRA, FOLIVORA)
}

\author{
A.R. Miño-Boilini ${ }^{1}$, C. Méndez ${ }^{1}$, S.I. Quiñones ${ }^{1}$, C.A. Luna ${ }^{1}$, A.E. Zurita ${ }^{1}$ y P. Cuaranta ${ }^{1}$ \\ ${ }^{1}$ Centro de Ecología Aplicada del Litoral (CECOAL)-Consejo Nacional de Investigaciones Científicas y Tecnológicas (CONICET) y Universidad \\ Nacional del Nordeste. Ruta 5, km 2,5, 3400 Corrientes, Argentina.angelmioboilini@yahoo.com.ar
}

Los Scelidotheriinae son un clado de perezosos terrestres milodóntidos, ampliamente representados en América del Sur desde el Mioceno Medio al Holoceno Temprano, que presentan un abundante registro en la Formación Toropí/Yupoí (Pleistoceno Tardío; ca. 52-35 ka) en la provincia de Corrientes. El hallazgo de un ejemplar asignable a Catonyx tarijensis procedente de esta unidad, en los alrededores de Bella Vista (Corrientes), con numerosas anomalías, permite ampliar el conocimiento acerca del desarrollo de patologías en este grupo de mamíferos. El material corresponde a un individuo adulto representado por cráneo, mandíbula y elementos del postcráneo, depositado en la Colección Paleontológica de la Universidad Nacional del Nordeste "Rafael Herbst" (CTES-PZ 7763). Mediante un análisis macroscópico y tomografía computada pudieron advertirse distintas anomalías en la serie dentaria izquierda, en donde el Mf1 presenta hipsodoncia, mientras el Mf2 se presenta como inclusión dentaria, no habiendo alcanzado la erupción, lo cual podría estar relacionado con el proceso infeccioso en la base del molariforme. Por su lado, la hemimandíbula izquierda presenta desarrollo de exostosis en los bordes alveolares, y desgaste diferencial del $\mathrm{mf} 2$. En la columna vertebral se observan osteofitos en los bordes de los cuerpos vertebrales, como así también un intenso crecimiento óseo en la región del ligamento longitudinal que ha determinado la fusión de dos vértebras dorsales. Estas últimas lesiones pueden ser asignadas a hiperostosis esquelética idiopática difusa asociada a una espondiloartropatía axial (EA), un tipo de artritis inflamatoria. Si bien las anomalías dentarias no habrían implicado complicaciones en el desarrollo, otras como la EA podrían haber tenido un efecto deletéreo sobre el individuo.

\section{NEW VERTEBRATE REMAINSS FROM THE HUINCUL FORMATION (CENOMANIAN-TURONIAN; UPPER CRETACEOUS) IN RÍO NEGRO, ARGENTINA}

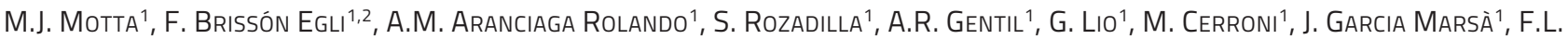 \\ Agnolín ${ }^{1,2,3}$, J.S. D'angelo' ${ }^{1}$, G.P. Álvarez-Herrera' ${ }^{1}$, C.H. Alsina' ${ }^{1}$, and F.E. Novas ${ }^{1,2 *}$ \\ 'Laboratorio de Anatomía Comparada y Evolución de los Vertebrados, Museo Argentino de Ciencias Naturales "Bernardino Rivadavia". \\ Av. Ángel Gallardo 470, C1405DJR Ciudad Autónoma de Buenos Aires, Argentina.matiasjmotta@gmail.com; mauro.a_guido@hotmail.com; \\ sebastianrozadilla@gmail.com; adrielgentil@gmail.com; mauricio.cerroni@gmail.com; jordalexix@hotmail.com; juliasdangelo@gmail.com; \\ geralvarezherrera@gmail.com; chalsina@yahoo.com.ar. \\ 2Consejo Nacional de Investigaciones Científicas y Técnicas (CONICET).Argentina.fedebe@gmail.com,fernovas@yahoo.com.ar \\ ${ }^{3}$ Área de Paleontología, Fundación de Historia Natural Félix de Azara, Centro de Estudios Biomédicos, Biotecnológicos, Ambientales y Diag- \\ nóstico (CEBBAD)-Universidad Maimónides. Hidalgo 775, C1405CBK Ciudad Autónoma de Buenos Aires, Argentina.fedeagnolin@yahoo.com.ar
}

The Violante's Farm is a fossiliferous locality located in the northwest of the province of Río Negro, Argentina. In this locality, the Huincul Formation (Neuquén Group, Cenomanian-Turonian, Upper Cretaceous) is widely exposed. Numerous vertebrate remains have been collected from this fossiliferous site and were recently published, including the enigmatic Gualicho shinyae Apesteguía et al., 2016, and the theropods Aoniraptor libertatem and Taurovenator violantei Motta et al., 2016. In a recent exploration carried out in this locality, a large number of vertebrate fossils were found and are preliminarily presented in this abstract. The remains represent different vertebrate clades that include: Lepisosteiformes cf. Lepidotes sp.; Sphenodontia Eilenodontinae indet.; Squamata indet.; Chelidae indet.; Crocodyliformes cf. Neosuchia; Titanosauria indet.; Ornithopoda indet.; Carcharodontosauridae indet.; Abelisauridae indet.; Megaraptoridae indet.; and Coelulosauria indet. The two Eilenodontinae specimens represent the first sphenodontian records for the Huincul Formation. The coelulosaurs, abelisaurid and carcharodontosaurid specimens show distinct autapomorphic traits and are different from previously known theropods found in the Huincul Formation. The good preservational state and the large number of specimens collected will allow increasing the knowledge about the fauna represented on the Huincul Formation. This large number of different clades of vertebrates in a single fossiliferous location positions the Huincul Formation as one of the richest vertebrate associations in Patagonia.

\footnotetext{
*Project supported by National Geographic Grant CP-096ER-17.
} 


\title{
DIVERSIDAD DE CALYPTOCEPHALELLIDAE EN EL EOCENO DE PATAGONIA
}

\author{
P. Muzzopappa ${ }^{1,2}$, A.M. Aranciaga Rolando ${ }^{3}$ y F. Agnolín $1,2,3$
}

${ }^{1}$ Fundación de Historia Natural "Félix de Azara", Centro de Estudios Biomédicos, Biotecnológicos, Ambientales y Diagnóstico (CEBBAD)Universidad Maimónides. Hidalgo 775, C1405CBK Ciudad Autónoma de Buenos Aires, Argentina.pmuzzopappa@fundacionazara.org.ar; pmuzzopappa@gmail.com

${ }^{2}$ Consejo Nacional de Investigaciones Científicas y Técnicas (CONICET).

${ }^{3}$ Laboratorio de Anatomía Comparada, Museo Argentino de Ciencias Naturales "Bernardino Rivadavia". Av. Ángel Gallardo 470, C1405DJR Ciudad Autónoma de Buenos Aires, Argentina.

Recientemente se ha intensificado el estudio de la herpetofauna fósil de Sudamérica, lo que ha resultado en el conocimiento de numerosas especies nuevas de anuros. Para el grupo de las "ranas modernas" (Neobatrachia), esto redundó en un nuevo entendimiento respecto de su evolución. En ese contexto, el estudio de fósiles de Patagonia nos está mostrando una diversidad mucho mayor a la previamente conocida. La Formación La Huitrera, de edad Eoceno Temprano-Medio y para la cual se conoce la especie Calyptocephalella pichileufenis Gómez, Báez y Muzzopappa, 2011, está brindando numerosos restos de anuros que se encuentran en estudio. Para ese mismo período, hasta el momento solo dos especies fueron asignadas al género Calyptocephalella en base a unos pocos restos en localidades distantes una de la otra (C. pichileufensis, en Río Pichileufú, Río Negro y C. casamayorensis Schaeffer, 1949, en Cañadón Hondo, Chubut, Argentina). La revisión de especímenes exhumados de la Formación La Huitrera, en las localidades Río Pichileufú y El Chacay, nos muestra al menos dos especies del género en simpatría, tal vez hasta cohabitando las mismas lagunas. El número, sin embargo, podría aumentar al menos en una especie al término de la preparación y estudio de más especímenes de los mismos estratos. Durante la mayor parte del Paleógeno una selva húmeda tropical cubrió gran parte de la Patagonia, de la que se registra una excepcional diversidad en la flora durante el Eoceno. A esta diversidad se suma la de anuros aquí presentada, contribuyendo a completar el escenario de dicha selva.

\section{ANÁLISIS DE LOS CANALES SEMICIRCULARES ANTERIOR Y POSTERIOR DEL OÍDO INTERNO DE DISTINTOS GRUPOS DE THEROPODA}

\author{
M.N. Nieto ${ }^{1}$, A. Paulina-Carabajal ${ }^{2}$ y J.M. Leardi ${ }^{3 *}$ \\ ${ }^{1}$ Facultad de Ciencias Exactas y Naturales, Universidad de Buenos Aires. Intendente Güiraldes 2160, Ciudad Universitaria, Pabellón 2, \\ C1428EGBA Buenos Aires, Argentina.mnicolasnieto@hotmail.com \\ ${ }^{2}$ Instituto de Investigaciones en Biodiversidad y Medioambiente, Universidad Nacional del Comahue-Consejo Nacional de Investigaciones \\ Científicas y Tecnológicas (CONICET-UNCO). Quintral 1250, R8400FRF San Carlos de Bariloche, Argentina. a.paulinacarabajal@conicet.gov.ar \\ ${ }^{3}$ Departamento de Ciencias Geológicas, Facultad de Ciencias Exactas y Naturales, Instituto de Estudios Andinos "Don Pablo Groeber" (IDEAN), \\ Universidad de Buenos Aires-Consejo Nacional de Investigaciones Científicas y Tecnológicas (CONICET). Intendente Güiraldes 2160, Ciudad \\ Universitaria-Pabellón II, C1428EGA Ciudad Autónoma de Buenos Aires, Argentina. juanmartinleardi@gmail.com
}

En estudios paleoneurológicos recientes del oído interno de los dinosaurios, el aumento del tamaño del canal semicircular anterior (CSA) con respecto al canal semicircular posterior (CSP) ha sido utilizado como indicador de agilidad. En aquellos casos donde los CSA y CSP son sub-iguales en tamaño, se habla de una reducción del primero pero no de un aumento de este último. En los terópodos, el CSA tiene siempre un tamaño absoluto mayor que el CSP, pero nunca se evaluó el tamaño relativo de este último a lo largo del linaje. En el presente trabajo, se probó mediante un análisis comparativo el tamaño absoluto y el radio de curvatura de los canales del oído interno de 16 taxones de terópodos (representando neoterópodos basales, abelisaurios, megaraptóridos, allosauroideos y coelurosaurios), comprendiendo el rango temporal Triásico-Cretácico. Se compararon estos resultados contra el tamaño corporal de cada individuo y se observó que hay una correlación entre el tamaño relativo del CSP y la masa corporal. No obstante, se determinó que el CSP no presenta diferencias sustanciales en el radio de curvatura entre los distintos grupos de terópodos, independientemente de su tamaño corporal. Esto indicaría que el CSP, desde temprano en el linaje de los terópodos, no habría sufrido fuertes modificaciones. El CSP de los terópodos presenta un radio de curvatura menor con respecto al CSA desde el Triásico, y por lo tanto, no sería útil como indicador de agilidad.

\footnotetext{
*Proyecto subsidiado por PICT 2016-0481 (APC).
} 


\title{
ESTUDIO TAFONÓMICO DE LOS ELEMENTOS ESQUELÉTICOS DE HIPPARION RECUPERADOS DEL YACIMIENTO DE VENTA DEL MORO (MIOCENO SUPERIOR, ESPAÑA)
}

\author{
A. NúÑez ${ }^{1}$, M.D. Marin-MONFort² Y P. MONTOYA ${ }^{3}$ \\ 1,3Universidad de Valencia, Departamento de Geología, Doctor Moliner, 50, 46100 Burjassot, Valencia, España.alizia_zgz12@hotmail.com; \\ Plinio.Montoya@uv.es \\ 2Museo Nacional de Ciencias Naturales, José Gutiérrez Abascal 2, 28006 Madrid, España.mcndm868@mncn.csic.es
}

El yacimiento paleontológico de Venta del Moro (Valencia, España) es una de las localidades más relevantes del Mioceno terminal europeo debido a la extraordinaria paleobiodiversidad en él registrada. El ambiente de depósito ha sido interpretado como un sistema de lagos palustres, con fluctuaciones ocasionales del nivel freático. Esta interpretación queda respaldada por los caracteres tafonómicos observados en los fósiles, que concuerdan con este tipo de medios acuáticos. En el presente estudio se ha realizado un análisis tafonómico a partir de una muestra de 1093 fósiles del género Hipparion recuperados en este yacimiento entre 1995 y 2006. Para ello, se ha analizado la distribución espacial, la forma de los fósiles y la dispersión de restos, diferenciando entre unidades sedimentarias. Los resultados indican que durante la evolución del yacimiento no se produjeron episodios significativos de transporte de elementos esqueléticos por corrientes hídricas. Por otro lado, se han identificado alteraciones como marcas y fracturas generadas por carnívoros, estriación por pisoteo, marcas de roedores, marcas de raíces de plantas, así como signos de meteorización, abrasión, fracturación y deformación generados por procesos geológicos. Además, los fluidos diagenéticos han condicionado la conservación de los fósiles al generar encostramiento mineral limonítico y corrosión química inorgánica. Se concluye que los dos factores más importantes que han intervenido en la formación y características tafonómicas del yacimiento son: 1) la acción de depredadores, puesto que en muchas ocasiones han actuado como agentes acumuladores de los restos en el lago, y 2) la propia dinámica geológica del sistema lacustre-palustre.

\section{PALEONEUROLOGÍA DEL TIRANOSÁURIDO DASPLETOSAURUS SP. (DINOSAURIA, THEROPODA): MORFOLOGÍA DEL OÍDO INTERNO}

\author{
A. Paulina-Carabajal ${ }^{1}$, N. Nieto ${ }^{2}$, P.J. Currie $^{3}$ Y T. Miyashita ${ }^{3 *}$
}

${ }^{1}$ Instituto de Investigaciones en Biodiversidad y Medioambiente, Universidad Nacional del Comahue-Consejo Nacional de Investigaciones Científicas y Tecnológicas (CONICET-UNCO). Quintral 1250, R8400FRF San Carlos de Bariloche, Argentina. a.paulinacarabajal@conicet.gov.ar ${ }^{2}$ Facultad de Ciencias Exactas y Naturales, Universidad de Buenos Aires. Intendente Güiraldes 2160, Ciudad Universitaria, Pabellón 2, C1428EGBA Buenos Aires, Argentina.

${ }^{3}$ University of Alberta, CW405 Biological Sciences Building. Edmonton, Alberta T6G 2E9, Canada.

La morfología del oído interno de los tiranosáuridos se conoce en tres especies: Tyrannosaurus rex Osborn, Gorgosaurus libratus Lambe y Alioramus altai Kurzanov. El oído interno es una estructura importante para el estudio de los sentidos de animales extintos debido a su rol en el balance, equilibrio y audición. Utilizando tomografías computadas, se describe por primera vez el oído interno de una posible nueva especie de Daspletosaurus Russell (TMP 2001.36.01), un tiranosáurido del Cretácico Superior de Canadá. En el ejemplar los canales semicirculares (CS) y el tronco común son delgados y las ámpulas son poco desarrolladas. EI CSA es mayor que el CSP (aproximadamente 40\% mayor) y se desarrolla por encima del tronco común. En vista dorsal los CSA y CSP presentan aproximadamente la misma extensión, siendo el ángulo entre ambos cercano a los $85^{\circ}$, similar al presente en $T$. rex y A. altai y algo menor que en $G$. libratus. La ventana oval se orienta levemente hacia atrás, como indica el calco del receso columelar. La lagena es delgada, cónica y relativamente corta comparada con T. rex y A. altai. Si bien, la morfología del oído interno de Daspletosaurus sp. no difiere en gran manera de la de otros tiranosáuridos estudiados, este muestra una mayor similitud con Gorgosaurus (Albertosaurinae) que con Tyrannosaurus (Tyrannosaurinae). Futuros análisis integradores de la morfología endocraneana (cerebro y cerebelo) y el radio de curvatura de los CS de este grupo permitirán realizar estimaciones más precisas del desarrollo relativo de los sentidos asociados al laberinto.

\footnotetext{
*Proyecto subsidiado por PICT 2016-0481 (APC).
} 


\title{
PRIMERA ASOCIACIÓN FAUNÍSTICA DEL HOLOCENO TEMPRANO EN EL SUDOESTE DE ENTRE RÍOS
}

\author{
M.J Peralta ${ }^{1}$ y B.S. Ferrero $0^{1,2}$
}

\begin{abstract}
${ }^{1}$ Laboratorio de Paleontología de Vertebrados, Centro de Investigaciones Científicas y Transferencia de Tecnología a la Producción (CICYTTP)Consejo Nacional de Investigaciones Científicas y Tecnológicas (CONICET), Prov. De Entre Ríos-Universidad Autónoma de Entre Ríos. Materi y España, E3105BWA Diamante, Entre Ríos, Argentina. matiasperalta1991@gmail.com

${ }^{2}$ Facultad de Ciencia y Tecnología, Universidad Autónoma de Entre Ríos (UADER), Sede Diamante. Tratado del Pilar 314, E3105AUQ Diamante, Entre Ríos, Argentina.brendaferrero@cicyttp.org.ar
\end{abstract}

Esta contribución constituye el primer estudio de microvertebrados fósiles del Cuaternario de Entre Ríos. El perfil analizado se encuentra en la barranca del Arroyo Doll ( $32^{\circ} 18^{\prime} 24^{\prime \prime} \mathrm{S}, 60^{\circ} 25^{\prime} 41^{\prime \prime}$ ), localidad Molino Doll. A partir de conchillas de gasterópodos, se obtuvo la edad radiocarbónica de 9,990 \pm 140 años A.P. (Holoceno Temprano). Se reconocieron peces como Synbranchus cf. marmoratus Bloch, 1975, cf. Crenicichla Heckel, 1840 y pequeños charácidos (cf. Astyanax Baird y Girard, 1854 y cf. Hoplias Gill, 1903), anuros, reptiles como Amphisbaena Wagler, 1824, Colubroidea y Squamata y aves como Gallinula cf. galeata (Lichtenstein, 1818) y Ciconiiformes y mamíferos como Dasypus cf. hybridus Desmarest, 1804 y pequeños roedores como Ctenomys sp. Blainville, 1826, cf. Akodon Meyen, 1833 y cf. Holochilus Meyen, 1833. La mayoría de los taxones reconocidos constituyen primeros registros fósiles para el Holoceno de Entre Ríos. Además, actualmente están registrados en la provincia. Los vertebrados reconocidos están vinculados a condiciones ambientales semejantes a las actuales para el área, de tipo templado-cálido y húmedo con abundantes precipitaciones. Es necesario profundizar en el estudio de los microvertebrados desde un abordaje multidisciplinario que incluya la estratigrafía, la geología clásica y secuencial y análisis cronológico a fin de obtener resultados sólidos para realizar interpretaciones de carácter paleoambiental y paleoclimático capaces de construir un esquema regional.

\section{IMPLICANCIAS LOCOMOTORAS DE LA CONFORMACIÓN MIO-OSTEOLÓGICA DE LA EXTREMIDAD ANTERIOR DE MACRAUCHENIA PATACHONICA OWEN, 1840}

\author{
M.C. Prieto ${ }^{1}$ y A. ElisSAmburu 2,3
}

${ }^{1}$ Instituto Multidisciplinario de Biología Vegetal (IMBIV)-Consejo Nacional de Investigaciones Científicas y Tecnológicas (CONICET). Av. Vélez Sarsfield 1666,X5016GCN Córdoba Capital, Córdoba, Argentina.prietomc@agro.unc.edu.ar

2Cátedra de Anatomía Comparada, Facultad de Ciencias Naturales y Museo, Universidad Nacional de la Plata. Calle 64 s/n entre 120 y diagonal 113, B1904DZA La Plata, Buenos Aires, Argentina. elissamburu@hotmail.com

${ }^{3}$ Consejo Nacional de Investigaciones Científicas y Tecnológicas (CONICET).

El análisis de la locomoción de los ungulados sudamericanos endémicos constituye una de las claves para interpretar la forma de vida y ecología este grupo de mamíferos extintos. En esta contribución se analiza la osteología y miología de la extremidad anterior de M. patachonica y se discuten sus implicancias locomotoras. Macrauchenia presenta una cintura pectoral con escápula rectangular y espina bien pronunciada que favorece el desarrollo de los músculos deltoides, tríceps braquial, bíceps braquial, supraespinoso e infraespinoso; húmero con amplio desarrollo de cresta deltoidea y de epicóndilos (origen del flexor digital superficial, extensor digital lateral y ligamento colateral medial, hacia medial, y del extensor carporadial, extensor digitaly ligamento colateral lateral, hacia lateral); zeugopodio largo con fusión de ulna y radio, este último con un proceso hacia medial que aumenta una de las áreas de origen del flexor digital superficial. Autopodio robusto que consta de tres dígitos con metacarpos poco elongados en relación al zeugopodio, con postura digitígrada. Estas características indicarían un amplio desarrollo de los músculos adaptados al soporte de la masa corporal, así como de aquellos involucrados en la flexión y extensión del zeugopodio y dígitos, que favorecen la distribución de peso durante el paso, y el desarrollo de los ligamentos colaterales del codo que evitan la aducción y abducción excesivas. En conjunto, las características presentes en M. patachonica podrían interpretarse como adaptaciones necesarias para el movimiento y estabilización de un animal de gran porte con locomoción cursorial de velocidad general moderada a lenta. Estudios complementarios podrían confirmar esta interpretación. 


\title{
LOS XENARTHRA (MAMMALIA) DE LA FORMACIÓN TAFNA (MIOCENO TARDÍO-PLIOCENO) DE LA PROVINCIA DE JUJUY, NOROESTE DE ARGENTINA
}

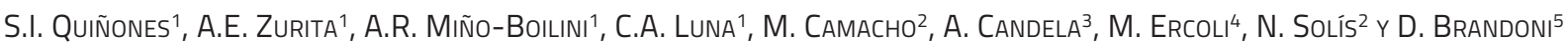 \\ ${ }^{1}$ Centro de Ecología Aplicada del Litoral (CECOAL)-Consejo Nacional de Investigaciones Científicas y Tecnológicas (CONICET) y Universidad \\ Nacional del Nordeste. Ruta 5, km 2,5, 3400 Corrientes, Argentina. angelmioboilini@yahoo.com.ar \\ ${ }^{2}$ Instituto de Geología y Minería, Universidad Nacional de Jujuy. Av. Bolívar 1661, 4600 San Salvador de Jujuy, Jujuy, Argentina. \\ ${ }^{3}$ División Paleontología Vertebrados, Museo de La Plata, Facultad de Ciencias Naturales y Museo, Universidad Nacional de La Plata. Paseo del \\ Bosque s/n, B1900FWA La Plata, Argentina. \\ ${ }^{4}$ Instituto de Ecorregiones Andinas (INECOA)-Consejo Nacional de Investigaciones Científicas y Tecnológicas (CONICET) Instituto de Geología \\ y Minería (IdGyM), Universidad Nacional de Jujuy. Av. Bolivia 1661, Y4600GNE San Salvador de Jujuy, Jujuy, Argentina. \\ ${ }^{5}$ Laboratorio de Paleontología de Vertebrados, Centro de Investigaciones Científicas y Transferencia de Tecnología a la Producción (CICYTTP)- \\ Consejo Nacional de Investigaciones Científicas y Tecnológicas (CONICET), Prov. De Entre Ríos-Universidad Autónoma de Entre Ríos. Materi \\ y España, E3105BWA Diamante, Entre Ríos, Argentina.
}

En el Noroeste de Argentina se encuentra una de las secuencias fosilíferas más completas del Neógeno tardío, particularmente en las provincias de Catamarca, Jujuy y Tucumán. Más específicamente, en la "Quebrada de Humahuaca" (Jujuy) se han reportado yacimientos de interés paleontológico que incluyen las Formaciones Uquía, Maimará y Tilcara en el ámbito de la Cordillera Oriental. En ellas, los xenartros constituyen uno de los clados más conspicuos y de mayor frecuencia de registros. En tanto, recientes trabajos de prospección han puesto de relieve el alto potencial en localidades de la Puna septentrional, en el límite entre Argentina y Bolivia. En esta contribución se analiza la diversidad de Xenarthra registrados en la Formación Tafna en las localidades de Casira (3627 m s.n.m) y Calahoyo (3639 m s.n.m), provincia de Jujuy. En el miembro inferior de esta Formación se registraron Tardigrada [Pyramiodontherium bergi (Megatheriinae)] y Cingulata [Macrochorobates chapalmalensis, Macrochorobates cf. M. scalabrini y Stenotatus sp. (Dasypodidae) y Eosclerocalyptus sp. (Glyptodontidae)]. En el miembro superior los hallazgos se encuentran limitados a Tardigrada [Pleurolestodon cf. P. acutidens (Mylodontinae), Mylodontinae indet. y Mylodontidae indet.]. Desde una perspectiva paleofaunística se destaca la existencia de una marcada diferencia entre ambos miembros, dado por la diversidad de Cingulata en el miembro inferior y la abundancia de Tardigrada Mylodontidae en la sección superior. Basado en la presencia delos Dasypodidae Macrochorobates cf. M. scalabrini y Stenotatus sp. se sugiere una edad Mioceno Tardío para la base de la secuencia.

\section{NUEVOS RESTOS DE ANKYLOSAURIA DEL SALITRAL MORENO Y CONSIDERACIONES SISTE- MÁTICAS SOBRE SU ARMADURA}

\section{F.J. RIGUETTI ${ }^{1}$}

${ }^{1}$ Fundación de Historia Natural Félix de Azara, Centro de Estudios Biomédicos, Biotecnológicos, Ambientales y Diagnóstico (CEBBAD)Universidad Maimónides. Hidalgo 775, C1405CBK Ciudad Autónoma de Buenos Aires, Argentina. facu.riguetti@gmail.com

Nuevos materiales de Ankylosauria (MPCA-Pv-600/606) provenientes de la Formación Allen (Campaniano-Maastrichtiano) en Salitral Moreno (Río Negro) fueron encontrados en la colección del Museo Provincial Carlos Ameghino (Cipolletti), e incluidos al ejemplar ya conocido procedente del mismo sitio. Los osteodermos nuevos y conocidos pueden agruparse en 4 categorías compatibles con las conocidas para nodosaurios: anillos cervicales, espinas cervicopectorales, escudos dorsosacrales, y escudos caudales. El ejemplar presenta al menos dos medios anillos cervicales (los Nodosauridae suelen presentar tres) formados por osteodermos de distinta morfología: escudos mediales cónicos romos, laterales con una quilla alta, y distales cónicos, altos, con un borde anterior comprimido lateromedialmente. Esta variación en escudos cervicales es más similar a lo observado en Nodosauridae que en Ankylosauridae, donde los escudos suelen ser similares, están unidos por una banda ósea basal y carecen de espinas. Las espinas cervicopectorales mantienen la morfología de las cervicales distales, pero son más altas y de base cóncava. Los escudos dorsales y sacrales son deprimidos y alargados, cóncavos ventralmente, y presentan un ápice dorsal romo. Los escudos caudales son cónicos con el borde basal anterior proyectado y una base profunda. Estas morfologías de osteodermos coinciden con las presentes en Nodosauridae como Sauropelta y Borealopelta, aportando una idea aproximada del arreglo de las mismas y sugiere una aproximación filogenética del ejemplar argentino a estos taxones. La armadura es muy diferente a la del Ankylosauria basal Kunbarrasaurus (Cretácico Inferior de Australia), aportando evidencia a la hipótesis de al menos dos eventos independientes de inmigración de anquilosaurios hacia Gondwana. 


\title{
PLEUROLESTODON ROVERETO, 1914 (XENARTHRA, MYLODONTINAE) EN ÁREAS DE ALTURA DEL NEÓGENO TARDÍO DE LA PROVINCIA DE JUJUY, ARGENTINA
}

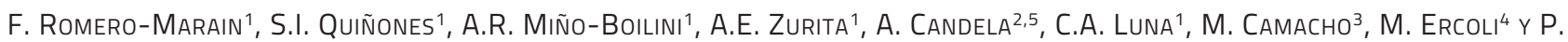 \\ CUARANTA 1
}
${ }^{1}$ Centro de Ecología Aplicada del Litoral (CECOAL)-Consejo Nacional de Investigaciones Científicas y Tecnológicas (CONICET) y Universidad Nacional del Nordeste. Ruta 5, km 2,5, 3400 Corrientes, Argentina.angelmioboilini@yahoo.com.ar
2División Paleontología Vertebrados, Museo de La Plata, Facultad de Ciencias Naturales y Museo, Universidad Nacional de La Plata. Paseo del Bosque s/n, B1900FWA La Plata, Argentina.
${ }^{3}$ Instituto de Geología y Minería (IdGyM), Universidad Nacional de Jujuy. Av. Bolivia 1661, Y4600GNE San Salvador de Jujuy, Jujuy, Argentina. ${ }^{4}$ Instituto de Ecorregiones Andinas (INECOA)-Consejo Nacional de Investigaciones Científicas y Tecnológicas (CONICET) Instituto de Geología y Minería (IdGyM), Universidad Nacional de Jujuy. Av. Bolivia 1661, Y4600GNE San Salvador de Jujuy, Jujuy, Argentina.
${ }^{5}$ Consejo Nacional de Investigaciones Científicas y Tecnológicas (CONICET).

El perezoso Pleurolestodon fue reconocido por Rovereto en 1914 e incluye tres especies en Argentina: P. acutidens (especie tipo), P. avitus y P. macrodon, del "Araucanense" (Mioceno Tardío-Plioceno) del Valle de Santa María, provincia de Catamarca. A esto se suma el reconocimiento de $P$. dalenzae para el Mioceno Tardío-Plioceno? de Bolivia. Aquí damos a conocer cinco especímenes en distintos estadios ontogenéticos asignables a Pleurolestodon representados por cráneos, mandíbulas y algunos elementos del postcráneo, pertenecientes al Museo de Geología, Mineralogía y Paleontología-Instituto de Geología y Minería de la UNJu (JUY-P-s/n). Estos fueron exhumados de la Formación Tafna (Mioceno Tardío-Plioceno) en los alrededores de la localidad de Casira ( 3627 m s.n.m.), provincia de Jujuy, y provienen de depósitos eólicos compuestos por arena fina y cemento calcáreo, con estratificación cruzada planar de gran escala (dunas). Los especímenes presentan: a) series dentarias superiores claramente divergentes; b) ausencia de diastema superior e inferior entre el primer y segundo diente; c) Mf2 de sección triangular, con un fuerte surco lingual; d) arco cigomático ubicado a nivel del Mf2 y Mf3 en vista palatal. Estos caracteres permiten su inclusión en Pleurolestodon, en tanto que el Cf1 y los Mf2 y Mf3 de sección triangular indican una estrecha afinidad morfológica con Pleurolestodon cf. P. acutidens. Estos materiales representan el primer registro de Pleurolestodon para el Mioceno Tardío-Plioceno de Jujuy con buen control geográfico y estratigráfico y en distintos estadios ontogenéticos. Posteriores estudios permitirán una mejor comprensión del género, particularmente en relación a aspectos de desarrollo ontogenético.

\section{PECES DEL MIOCENO TEMPRANO DE LOS ACANTILADOS DE LA LOCALIDAD DE LAS GRUTAS, RÍO NEGRO}

\author{
F.M. Sesto 1 , M.E. Almada², E.S. Monsalvo', S. Bogan³ y F.L. Agnolín 3,4
}

${ }^{1}$ Cátedra de Anatomía Comparada, Facultad de Ciencias Naturales y Museo, Universidad Nacional de La Plata, Calle 64 3, B1904DZA La Plata, Buenos Aires, Argentina.facundomartinsesto@hotmail.com; assaul3@hotmail.com

${ }^{2}$ Facultad de Ciencias Naturales y Museo, Universidad Nacional de La Plata. Avenida 122 y 60, 1900 La Plata, Buenos Aires, Argentina. marcos.almada.225@gmail.com

${ }^{3}$ Fundación de Historia Natural "Félix de Azara", Departamento de Ciencias Naturales y Antropología, Centro de Estudios Biomédicos, Biotecnológicos, Ambientales y Diagnóstico (CEBBAD), Universidad Maimónides, Hidalgo 775, piso 7, C1405CBK Ciudad Autónoma de Buenos Aires, Argentina.sergiobogan@yahoo.com.ar

"Laboratorio de Anatomía Comparada y Evolución de los Vertebrados, Museo Argentino de Ciencias Naturales "Bernardino Rivadavia". Av. Ángel Gallardo 470, C1405DJR Ciudad Autónoma de Buenos Aires, Argentina.fedeagnolin@yahoo.com.ar

Se describen restos de peces procedentes de los acantilados de la localidad de Las Grutas, provincia de Río Negro, Argentina. Las sedimentitas marinas portadoras de esta paleoictiofauna se corresponden a aquellos sedimentos depositados durante la transgresión del mar Patagoniano y pertenecen al Miembro Saladar, el cual forma parte de la Formación Gran Bajo del Gualicho. Se caracterizan por ser areniscas bioclásticas blanco grisáceas a amarillas y ocres, coquinas, pelitas y yesos las cuales presentan estratificación planar y hardgrounds. En base a datos geológicos y paleofaunísticos la edad de estos depósitos correspondería al Mioceno Temprano alto-Mioceno Medio bajo. Ocho especies de condrictios y dos de osteíctios fueron identificadas. Los condrictios se encuentran representados por Echinorhinus pozzii (Ameghino, 1906), Carcharodon (Cosmopolitodus) hastalis (Agassiz, 1938), Carcharoides totuserratus (Ameghino, 1901), Carcharocles megalodon (Agassiz, 1835), Galeocerdo aduncus (Agassiz, 1843), Physogaleus contortus (Gibbes, 1849), Heterodontus sp. (Blainville, 1816) y Myliobatidae (Bonaparte, 1838); mientras que Chilomycterus sp. (Brisout de Barneville, 1846) y una especie indeterminada de pleuronectiforme, conforman los registros de osteíctios. 


\title{
EL REGISTRO DE GLYPTODONTINAE (GLYPTODONTIDAE) EN LA FORMACIÓN CERRO AZUL, PROVINCIA DE LA PAMPA, ARGENTINA
}

\author{
R. Sostillo ${ }^{1,2}$, C.I. Montalvo², F. Cuadrelli ${ }^{3}$ y A.E. Zurita ${ }^{3 *}$ \\ ${ }^{1}$ Consejo Nacional de Investigaciones Científicas y Técnicas (CONICET). \\ ${ }^{2}$ Facultad de Ciencias Exactas y Naturales, Universidad Nacional de La Pampa. Av. Uruguay 151, L6300CLB Santa Rosa, La Pampa, Argentina. \\ renata.sostillo@gmail.com \\ ${ }^{3}$ Centro de Ecología Aplicada del Litoral (CECOAL)-Consejo Nacional de Investigaciones Científicas y Tecnológicas (CONICET) y Universidad \\ Nacional del Nordeste. Ruta 5, km 2,5, 3400 Corrientes, Argentina.
}

Los registros más antiguos de Glyptodontinae (Glyptodontidae) corresponden al género Boreostemma (Mioceno-Plioceno Temprano de Colombia y Venezuela). Sin embargo, en lo que respecta al extremo sur de América del Sur, los Glyptodontinae más antiguos corresponden a Glyptodontidium tuberifer Cabrera 1944 del "Araucanense" (Mioceno Tardío-Plioceno Temprano) de la provincia de Catamarca (Argentina). En esta contribución se da a conocer la presencia de porciones de osteodermos asignables tentativamente a Glyptodontinae procedentes de la localidad de Cerro La Bota (Formación Cerro Azul, provincia de La Pampa). Dichos restos, aunque fragmentarios, muestran caracteres que sugieren su inclusión en esa subfamilia (e.g., patrón de ornamentación en roseta compuesto por una figura central y una única serie de figuras periféricas; surcos central y radiales profundos y bien definidos; alto grado de desarrollo de las interdigitación es en las áreas de contacto entre osteodermos contiguos y superficie expuesta muy rugosa). Cerro La Bota está ubicada en el límite sudoeste del Bloque Central de La Pampa y los depósitos de la Formación Cerro Azul allí se interpretan como de un curso fluvial efímero. De esta localidad proceden el Chasichimys bonaerense y otros roedores octodóntidos protohipsodontes (Rodentia, Octodontidae) que justificaron la asignación del fósil recuperado al Piso/Edad Chasiquense (Mioceno Tardío temprano). De confirmarse la presencia de un Glyptodontinae en este depósito que contiene fauna chasiquense, estaríamos ante el registro más antiguo de la subfamilia en el sur de América del Sur. El hallazgo de nuevos y más completos ejemplares podrá confirmar o refutar esta hipótesis.

*PI Q002/17 y Proyecto 06-G, Facultad de Ciencias Exactas y Naturales, UNLPam.

\section{EL MIEMBRO POSTERIOR DE CYONASUA SP. (CARNIVORA, PROCYONIDAE) DE LA FORMACIÓN CHAPADMALAL (PLIOCENO TARDÍO), BUENOS AIRES. ANÁLISIS CUANTITATIVO E INFERENCIAS PALEOBIOLÓGICAS}

\begin{abstract}
J. TARQUINI ${ }^{1 *}$
${ }^{1}$ Laboratorio de Paleontología de Vertebrados, Centro de Investigaciones Científicas y Transferencia de Tecnología a la Producción (CICYTTP)Consejo Nacional de Investigaciones Científicas y Tecnológicas (CONICET), Prov. de Entre Ríos-Universidad Autónoma de Entre Ríos. Materi y España, E3105BWA Diamante, Entre Ríos, Argentina. julitarquini@gmail.com

Cyonasua Ameghino, 1985 es un prociónido extinto que habitó América del Sur durante el Mioceno Tardío-Pleistoceno Temprano. Con el objetivo de realizar inferencias paleobiológicas sobre este género se realizó un estudio morfométrico de elementos del miembro posterior relativamente completos pertenecientes al ejemplar MMP 5178 (Cyonasua sp.) de la Formación Chapadmalal (Plioceno Tardío). Se relevaron 21 medidas lineales del fémur, tibia, astrágalo y calcáneo de Cyonasua sp. y de 137 ejemplares de carnívoros actuales. Estos últimos fueron clasificados en categorías ecológicas discretas. La variación morfológica fue explorada mediante Análisis de Componentes Principales (ACP), Análisis Discriminante (AD), Análisis multivariado de la varianza (MANOVA), comparaciones múltiples y cálculo de índices morfo-funcionales. Las medidas fueron transformadas (ajuste geométrico) y se realizaron regresiones múltiples para evaluar el efecto del tamaño sobre la variación registrada. En el morfoespacio del ACP, Cyonasua sp. presenta valores cercanos a cero para el CP1 y CP2 y se ubica cercano a Procyon cancrivorus y Nasua nasua. El AD asigna a Cyonasua sp. a la categoría terrestre-trepador, el MANOVA indica diferencias significativas entre las categorías analizadas, que existen, según comparaciones múltiples, entre la mayoría de las categorías. Los índices morfo-funcionales indican que el fémur y la tibia son elementos robustos y fuertes. En conclusión, el miembro posterior de Cyonasua sp. presenta rasgos más relacionados con la fuerza que con la velocidad, con soporte de cargas altas, y hábitos terrestres trepadores, con semejanzas con taxones trepadores como Procyon y Nasua, este último también con habilidades cavadoras.
\end{abstract}

${ }^{*}$ Proyecto subsidiado por PICT-2016-2698. 


\title{
NUEVOS REGISTROS DE MAMÍFEROS EN LA FORMACIÓN BROCHERO (MIOCENO TARDÍO- PLIOCENO) EN SU ÁREA TIPO, CÓRDOBA, ARGENTINA
}

\author{
A.A. Tauber ${ }^{1-4}$, D. Álvarez ${ }^{2}$, F. Álvarez ${ }^{1}$, S. Centorbi ${ }^{1}$, J.A. Haro ${ }^{1-3}$, J.M. Krapovickas ${ }^{4}$, N. Imbarratta ${ }^{4}$, M.A. Pizarro ${ }^{1}$ y G. Nieto ${ }^{3}$ \\ ${ }^{1}$ Museo de Paleontología, Facultad de Ciencias Exactas, Físicas y Naturales, Universidad Nacional de Córdoba. Vélez Sarsfield 249, X5000JJC \\ Córdoba, Argentina.adantauber@gmail.com.ar \\ ${ }_{2}^{2}$ Museo Dr. Dalmacio Vélez Sarsfield. Camino provincial 23, X5199XAK Amboy, Provincia de Córdoba, Argentina. \\ ${ }^{3}$ Consejo Nacional de Investigaciones Científicas y Técnicas (CONICET). \\ "Museo Provincial de Ciencias Naturales "Dr. Arturo U. Illia”, Agencia Córdoba Cultura S. E. Av. Poeta Lugones 395, X5000HZD Córdoba, \\ Argentina.
}

Se registraron nuevos sitios y niveles de las secciones media a superior de la Formación Brochero (MontehermosenseChapadmalalense; Mioceno Tardío-Plioceno, Marplatense Vorohuense? Plioceno Tardío-Pleistoceno Temprano), así como nuevos restos de mamíferos fósiles en niveles arcillosos ubicados en el área tipo de esta unidad, en las proximidades de la localidad de Nono, departamento San Alberto, provincia de Córdoba. Algunos nuevos registros para esta formación son: Doellotatus chapadmalensis Bordas, 1933, Macrochorobates scalabrinii (Moreno y Mercerat, 1891) Scillato Yané, 1980 (Cingulata, Dasypodidae), Cardiomys cf. C. ameghinorium Rovereto, 1914 (Rodentia), Lagostomus (Lagostomopsis) sp. (Rodentia, Chinchillidae), Proterotheriidae gen et sp. indet. (Litopterna), Promacrauchenia antiquua (Ameghino, 1887) (Litopterna, Macraucheniidae), Pseudotypotherium cf. P. subinsigne (Rovereto, 1914) o Pseudotypotherium exiguum Cabrera, 1937 (Notoungulata, Mesotheriidae), Hemihegetotherium achataleptum Rovereto, 1914 y Paedotherium typicum (Ameghino, 1887) (Notoungulata, Hegetotheriidae). Se amplía la distribución geográfica de Macrochorobates scalabrinii, Promacrauchenia antiquua, y Pseudotypotherium cf. P. subinsigne o P. exiguum, Hemihegetotherium achataleptum y Paedotherium typicum. El paleoambiente de los niveles fosilíferos fue palustre marginal de una llanura de inundación, asociado a un sistema fluvial meandriforme. El registro de la asociación de Macrochorobates scalabrinii, Cardiomys cf. C. ameghinorium y probablemente Pseudotypotherium cf. P. subinsigne en un mismo sitio y nivel fosilífero basal de la Formación Brochero en su área tipo, sugiere una edad Huayqueriense para el mismo, siendo los mamíferos neógenos más antiguos registrados hasta el presente en la provincial de Córdoba. Esto permite verificar la hipótesis de la depositación diacrónica de oeste a este durante el neógeno en las Sierras Pampeanas Orientales.

\section{ANATOMÍA DE UN DESLIZ EPISTEMOLÓGICO: LA ARQUEOLOGÍA PAMPEANA Y SU ROL EN LA PROPAGACIÓN DEL CONCEPTO SESGADO DE SUPERVIVENCIA HOLOCENA DE LA MEGA- FAUNA}

\section{M.J. TOLEDO ${ }^{1}$}

1Estomba 1237, C1427CPC Ciudad Autónoma de Buenos Aires. loessoide@gmail.com

La cronología de la extinción de megafauna, y por ende la duración de cohabitación con el hombre, es objeto de profundos debates y señala el fin del Piso/Edad Lujanense. Históricamente, el límite superior del mismo fue definido en 8 ka ${ }^{14}$ C AP., desvinculando así el momento de extinción del de los profundos cambios ambientales acontecidos entre 13 y 12 ka AP. A partir de ello se aceptó, paradigmáticamente y durante casi tres décadas, la supervivencia holocena de dicha fauna. Sin embargo, nuestros estudios estratigráficos y tafonómicos en la región chaco-pampeana no la confirman, lo que nos indujo a explorar e intentar comprender la raíz epistemológica de estos conceptos. Encontramos que las dataciones taxón en tres sitios arqueológicos del área pampeana: La Moderna, Arroyo Seco Il y Campo Laborde, fueron determinantes en la definición temporal del techo de la biozona Equus (Amerhippus) neogaeus. Por diversos motivos metodológicos, principalmente la ausencia de análisis geoarqueológicos sólidos y sesgos en la valoración de la representatividad de las dataciones radiocarbónicas, estos sitios fueron erróneamente asignados al Holoceno Inferior a Medio. Si bien tardíamente se corrigieron las edades de Arroyo Seco, demostramos que los restos óseos de Laborde y La Moderna, fueron contaminados por materia orgánica más joven y que se encuentran en niveles edafizados de edad mayor a 12 ka AP. 


\title{
SOBRE EL REDESCUBRIMIENTO DE EJEMPLARES TIPO DE GLIPTODONTES URUGUAYOS EN EL MUSEO UNIVERSITARIO “FLORENTINO \& CARLOS AMEGHINO" (ROSARIO, ARGENTINA)
}

\author{
P. Toriño ${ }^{1}$, A.E. Zurita ${ }^{2}$, D. Perea ${ }^{1}$ y A. Mones ${ }^{3 *}$ \\ 1Facultad de Ciencias, Universidad de la República. Iguá 4225, 11.200 Montevideo, Uruguay.paleopablo@gmail.com; perea@fcien.edu.uy \\ ${ }^{2}$ Centro de Ecología Aplicada del Litoral (CECOAL)-Consejo Nacional de Investigaciones Científicas y Tecnológicas (CONICET) y Universidad \\ Nacional del Nordeste. Ruta 5, km 2,5,3400 Corrientes, Argentina. aezurita74@yahoo.com.ar \\ ${ }^{3}$ Franzensbadstrasse 7b, 86199 Augsburg, Alemania.a-mones@t-online.de
}

Entre las décadas de 1930 y 1950 los paleontólogos argentinos Lucas Kraglievich y Alfredo Castellanos describieron numerosos gliptodontes endémicos de Uruguay. Los ejemplares utilizados provenían de colecciones catalogadas de tres paleontólogos autodidactas uruguayos (Alejandro Berro, Bautista Rebuffo y Francisco Lucas Roselli), las cuales actualmente constituyen acervos de Museos homónimos. Si bien desde sus descripciones originales estos ejemplares han sido objeto de estudios pormenorizados y referencias comparativas en numerosos trabajos (indicando siempre sus repositorios originales), en las últimas décadas se ha constatado la ausencia de varios de ellos en sus respectivos museos. Paralelamente, investigaciones conducidas por autores del presente trabajo han permitido constatar la presencia de tales ejemplares en el Museo Universitario "Florentino \& Carlos Ameghino". Así, un total de 18 ejemplares detectados a la fecha, incluyendo holotipos, paratipos, lectotipos, paralectotipos y material referido, constituyen el producto de un flujo de materiales entre los mencionados investigadores y coleccionistas, destacándose casos de ejemplares tipo con sus restos "disgregados" entre ambos países. Entre los taxones involucrados se encuentran los Glyptodontinae "Boreostracon" corondanus CasteIlanos, 1959 (MUFCA-1134/1183) y "Pseudothoracophorus" depressus (Ameghino, 1881) (MUFCA-1280); los "Plohophorini" "Teisseiria" compressa Castellanos, 1940 (MUFCA-1266), "Berthawyleria" gracilis Castellanos, 1940 (MUFCA1267/1268/1269/1270/1271), "Berthawyleria" uncinata Castellanos, 1940 (MUFCA-1265), Pseudoplohophorus benvenutii (Castellanos, 1954) (MUFCA-1388), Pseudoplohophorus rebuffoi (Castellanos, 1954) (MUFCA-s/n), Stromaphoropsis scavinoi Kraglievich, 1932 (MUFCA-1272/1273/1274/1275) y Plohophorus sp. (MUFCA-1276); y el "Neuryurini" "Urotherium" interundatum (Ameghino, 1885) (MUFCA-1057). El propósito de la presente contribución es dar a conocer la situación de estos ejemplares, dado que a la fecha la mayor parte de esta información permanece inédita.

*Investigación financiada por el Programa Escala Docente - AUGM y Contribución al proyecto CSIC/UdelaR/C229-348.

\section{DICRAEOSAURID TEETH FROM THE MULICHINCO FORMATION (VALANGINIAN, LOWER CRETACEOUS), NEUQUÉN, ARGENTINA}

\author{
G.J. Windholz ${ }^{1,2}$, M.A. Baiano ${ }^{1,2}$, And J.G. Meso ${ }^{1 *}$
}

${ }^{1}$ Instituto de Investigación en Paleobiología y Geología (IIPG)-Consejo Nacional de Investigaciones Científicas y Tecnológicas (CONICET), Universidad Nacional de Río Negro. Av. Roca 1242, R8332EXZ Gral. Roca, Río Negro, Argentina.gwindholz@unrn.edu.ar; jgmeso@unrn.edu.ar 2Museo Carmen Funes. Av. Córdoba 55, Q8318EBA Plaza Huincul, Neuquén, Argentina. mbaiano@unrn.edu.ar

Available information about dental morphology of dicraeosaurid sauropods is scarce worldwide, only known from the Upper Jurassic Dicraeosaurus Janensch, 1914 and Suuwassea Harris and Dodson, 2004; and isolated teeth from the Lower Cretaceous putatively referred to Amargasaurus Salgado and Bonaparte, 1991. Here we report three teeth collected associated with a partially articulated dicraeosaurid skeleton from the Mulichinco Formation (Valanginian, Lower Cretaceous) in the locality Pilmatué, Neuquén province. The general morphology of the teeth indicates affinities with Diplodocoidea, based on a cylindrical middle crown, with a sub-circular cross section. Unfortunately the teeth lack the typical wear facet, precluding a comparison with other diplodocoids, dicraeosaurid, or even titanosaurian teeth. However, the specimens here described differ from rebbachisaurid teeth due to the oval shape in cross section from the middle crown to the apex. The crown here described lack of longitudinal grooves on the lingual aspect of the teeth, as in other Flagellicaudata teeth. The enamel is asymmetric, forming a thicker labial layer, like in Diplodocus Marsh 1878 and Dicraeosaurus. The specimens show an overall resemblance to Dicraeosaurus teeth, based on the curvature of the element and the presence of lateral crests in the crown. These materials plus those communicated in previous meetings from Bajada Colorada Formation represent the oldest dicraeosaurid teeth recorded in the Cretaceous, and provide new morphological information about the dental morphology of this emblematic sauropod group.

\footnotetext{
*Supported by UNC PhD Project (of G.J.W.), PIP-CONICET 0233/0683, UNRN-PI- 40-A-157, 297, 378, and Municipalidad de Las Lajas
} (Neuquén) (to R.A.C). 


\title{
ON PNEUMATIC STRUCTURES IN VERTEBRAE OF A DICRAEOSAURID DINOSAUR (SAUROPODA, DIPLODOCOIDEA) FROM THE MULICHINCO FORMATION (VALANGINIAN, LOWER CRETACEOUS), NEUQUÉN BASIN, ARGENTINA
}

\author{
G.J. Windholz ${ }^{1,2}$, R.A. Coria ${ }^{2,3}$, AND V.L. ZURRIAGuZ ${ }^{1 *}$
}

${ }^{1}$ Instituto de Investigación en Paleobiología y Geología (IIPG)-Consejo Nacional de Investigaciones Científicas y Tecnológicas (CONICET), Universidad Nacional de Río Negro. Av. Roca 1242, R8332EXZ Gral. Roca, Río Negro, Argentina.gwindholz@unrn.edu.ar; vzurriaguz@gmail.com ²Subsecretaría de Cultura de Neuquén, Museo Carmen Funes. Av. Córdoba 55, Q8318EBA Plaza Huincul, Neuquén, Argentina. rcoria@unrn.edu.ar ${ }^{3}$ Consejo Nacional de Investigaciones Científicas y Tecnológicas (CONICET).

Dicraeosauridae is a family of small to medium-size sauropod dinosaurs that includes the genera Dicraeosaurus (Janensch, 1914), Amargasaurus (Salgado and Bonaparte, 1991), Brachytrachelopan (Rauhut et al., 2005), Amargatitanis (Apesteguía, 2007), Suuwassea (Harris and Dodson, 2004), and possibly Dyslocosaurus (Mclntosh et al., 1992) and Dystrophaeus (Cope, 1877). Traditionally, it has been argued that the dicraeosaurid postcraneal skeleton represents a reduction of the pneumaticity compared with other Diplodocoidea. In fact two isolated and fragmentary cervical vertebrae of Dicraeosaurus sp. had been examined by using computed tomography (CT scanning), in which procamerate pneumatization type was recognized. Here we report preliminary results obtained from CT scanning vertebral elements of a new dicraeosaurid taxon from Patagonia. We have recognized the first record of camerate internal structure type in the dicraeosaurid cervical vertebrae (MLL-Pv-004 and MLL-Pv-002), represented by lateral pneumatic foramina that open into a large camera that occupies most of the centrum. Also, CT scanned images in both dorsal (MLL-Pv-005) and caudal (MLL-Pv-016) vertebrae show acamerate pattern, lacking fossae invading the respective centra. The cervical vertebrae of diplodocids such as Apatosaurus and Diplodocus are polycamerate, whereas the dorsal vertebrae of the rebbachisaurid Katepensaurus are camellate. Also, in the rebbachisaurid Tataouinea the caudal vertebrae and appendicular skeleton are invaded by pneumatic structures. In summary, we provide the first record of camerate internal structure type in dicraeosaurid cervical vertebrae, and confirm the relative reduction of pneumaticity in dicraeosaurid dorsal and caudal vertebrae with respect to other diplodocoid taxa.

${ }^{*}$ Research supported by grants from PIP-CONICET 0233/0683, UNRN-PI- 40-A-157/297/378, Municipalidad de Las Lajas (Neuquén) (to R.A.C) and Agencia Nacional de Promoción Científica y Técnica (PICT 2015-1021) (to V.L.Z.). PhD Project registered at Universidad Nacional del Comahue (by G.Windholz).

\section{DOS CLADOS, DOS ÁREAS DE DIVERSIFICACIÓN, DOS TIEMPOS DIFERENTES: LA HISTORIA DE GLYPTODON OWEN Y GLYPTOTHERIUM OSBORN (XENARTHRA, CINGULATA, GLYPTODONTIDAE), UN ESTUDIO COMPARATIVO}

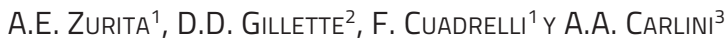 \\ ${ }^{1}$ Centro de Ecología Aplicada del Litoral (CECOAL)-Consejo Nacional de Investigaciones Científicas y Tecnológicas (CONICET) y Universidad \\ Nacional del Nordeste. Ruta 5, km 2,5, 3400 Corrientes, Argentina. \\ ${ }^{2}$ Museum of Northern Arizona, 3101, Fort Valley Road, Flagstaff, 86001, AZ, USA. \\ ${ }^{3}$ Laboratorio de Morfología Evolutiva y Desarrollo (MORPHOS) y División Paleontología de Vertebrados, Facultad de Ciencias Naturales y \\ Museo, Universidad Nacional de La Plata., Paseo del Bosque s/nº,B1900FWA La Plata, Buenos Aires, Argentina. \\ ${ }^{4}$ Consejo Nacional de Investigaciones Científicas y Tecnológicas (CONICET).
}

Glyptodon Owen, 1839 y Glyptotherium Osborn, 1903 representan taxones muy conspicuos de Glyptodontidae a partir del Neógeno más tardío y hasta el Holoceno Temprano en Sudamérica y Norteamérica, respectivamente. Es posible que Glyptotherium se haya originado en el norte de Sudamérica, o América Central, en torno a los de 3,9 Ma. A su vez, los primeros registros de Glyptodon provienen del Pleistoceno Temprano ( $c a 1,07 \mathrm{Ma}$ ) y sufre un proceso de diversificación que resulta muy posiblemente en no más de tres especies válidas (G. munizi Ameghino, G. elongatus Burmeister y G. reticulatus Owen) y, probablemente, una nueva especie andina, todas sudamericanas. En cuanto a Glyptotherium, es posible reconocer la existencia de dos crono-especies: Gl. texanum y Gl. cylindricum, cuya distribución primaria (no exclusiva) es norteamericana. Las relaciones entre Glyptodon y Glyptotherium han sido problemáticas desde el descubrimiento del linaje norteamericano (originalmente identificado como Glyptodon y posteriormente separado en un género diferente). Glyptodon es reconocido como un grupo natural, en tanto que a todos los gliptodontinos de Norteamérica se los ubica en Glyptotherium. En esta contribución llevamos a cabo un estudio morfológico comparativo entre las especies de Glyptodon y de Glyptotherium a fin de caracterizarlas e identificar potenciales sinapomorfías. Ambos géneros pueden ser diagnosticados a nivel craneano, mandibular, dentario y de la coraza dorsal y caudal. Ambos clados muestran una evolución morfológica lenta, que podría ser interpretado como anagénesis, particularmente en Glyptotherium. Los registros de Glyptodontinae en Centroamérica muestran una mayor afinidad morfológica con Glyptotherium que con Glyptodon. 


\title{
VII JORNADAS TÉCNICAS DE PALEONTOLOGÍA DE VERTEBRADOS
}

\author{
EXTRACCIÓN DE VERTEBRADOS FÓSILES EN ANTÁRTIDA
}

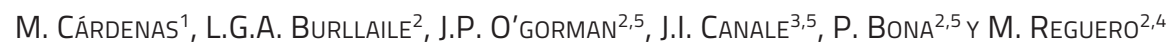 \\ ${ }^{1}$ Instituto de Investigación en Paleobiología y Geología (IIPG)-Consejo Nacional de Investigaciones Científicas y Tecnológicas (CONICET), \\ Universidad Nacional de Río Negro. Av. Roca 1242, R8332EXZ Gral. Roca, Río Negro, Argentina. mcardenas@unrn.edu.ar \\ 2División Paleontología Vertebrados, Museo de La Plata, Facultad de Ciencias Naturales y Museo, Universidad Nacional de la Plata. Paseo del \\ Bosque s/nº,B1900FWA La Plata, Buenos Aires, Argentina.leoacos@yahoo.com.ar; joseogorman@fcnym.unlp.edu.ar; paulabona26@gmail.com \\ ${ }^{3}$ Área Laboratorio e Investigación, Museo Municipal "Ernesto Bachmann", Villa El Chocón, Neuquén, Argentina. juanignaciocanale@yahoo.com.ar \\ ${ }^{4}$ Instituto Antártico Argentino. 25 de mayo 1143, B1650HMK San Martín, Buenos Aires, Argentina. regui@fcnym.unlp.edu.ar \\ ${ }^{5}$ Consejo Nacional de Investigaciones Científicas y Técnicas (CONICET).
}

Durante más de 40 años, el Museo de La Plata ha realizado tareas paleontológicas en Antártida a través de proyectos interinstitucionales con el Instituto Antártico Argentino (Dirección Nacional del Antártico). En este contexto, las tareas de extracción de vertebrados fósiles se ven afectadas por factores relacionados fundamentalmente con las bajas temperaturas, requiriendo estrategias de trabajo especiales. Se destacan: 1) la dificultad de realizar excavaciones en suelo congelado (permafrost) y 2) el fraguado y secado del yeso durante la confección de "bochones". La primera dificultad puede resolverse realizando excavaciones en etapas, esperando que la parte superior del permafrost se descongele y pase a formar la capa activa. Otra posibilidad es armar una carpa sobre el sector de excavación y calefaccionarlo. Cabe aclarar que la pérdida de consistencia del permafrost al descongelarse dentro de los bochones obliga a extremar las medidas del correcto empaquetamiento y embalaje de los materiales. La segunda dificultad puede resolverse reemplazando el papel mojado, que se utiliza para la capa de despegue de los bochones, por papel aluminio; mientras que la problemática relacionada con el fraguado del yeso se aminora trabajando a temperaturas relativamente altas $\left(>O \mathrm{C}^{\circ}\right)$, preparándolo con agua caliente y/o exponiendo el material a calor. Adicionalmente, puede utilizarse stretch film para brindar una contención alternativa al yeso. Finalmente, la buena confección y embalaje de bochones es de extrema importancia, considerando que durante el transporte (por helicópteros, avión o barco) estos pueden someterse a grandes esfuerzos y en ocasiones su manipulación es realizada sin inspección del personal científico.

\section{TRABAJOS DE PREPARACIÓN Y CONSOLIDACIÓN DE UN PEIROSAURIDAE PROCEDENTE DE RINCÓN DE LOS SAUCES, NEUQUÉN}

\section{FUENTES ${ }^{1}$}

'Museo Municipal "Argentino Urquiza". Jujuy y Chaco s/n Q8319BFA Rincón de los Sauces, Provincia del Neuquén, Argentina. carlosfuentesh@hotmail.com

Importantes hallazgos de restos fósiles han sido realizados durante distintas salidas de exploración paleontológica en el área de Cerro Overo, localidad ubicada a unos 50 km al suroeste de Rincón de los Sauces, Neuquén. En el año 2016 se realizó una campaña paleontológica para rescatar materiales que fueron identificados como restos de un crocodyliforme. El rescate de estos se realizó mediante un bochón de yeso, el cual fue trasladado al laboratorio del "Museo Municipal Argentino Urquiza" para su posterior limpieza. Los trabajos de preparación de los restos, los cuales están compuestos por una mandíbula casi completa, se iniciaron con la apertura del bochón y la remoción del sedimento (arcilla). El avance en los trabajos, permitió observar que la pieza conserva buena preservación solo con algunas fisuras. Una vez extraído del bochón el material fue sometido a una preparación mecánica utilizando el martillo neumático Paleo-Aro, y accionando sobre las roturas con cianocrilato y resinas sintéticas. Finalizados los trabajos de preparación, se confeccionó una cama de espuma de polietileno para proteger el material y posteriormente depositarlo en la colección del Museo. Actualmente los trabajos de investigación han finalizado, tratándose de una nueva especie de Crocodyliforme Peirosauridae llamada Kinesuchus overoi. 


\title{
LA DIVULGACIÓN DE LA PALEONTOLOGÍA EN ARAGÓN MEDIANTE YACIMIENTOS DE ICNITAS. EL YACIMIENTO OLVIDADO DE ABABUJ
}

\author{
C.M. GÓMEZ ${ }^{1}$ y E.I. SEGARRA ${ }^{1}$
}

1Departamento de Geología (Paleontología), Universidad de Zaragoza. C/ Pedro Cerbuna 12, 50009 Zaragoza, España.680450@unizar.es; iriaseoli@hotmail.com

Cualquier persona ajena al mundo de la paleontología puede conocerla mediante restos fósiles tales como dientes o huesos. Sin embargo, pocos son los que podrán identificar la palabra 'icnitas' como fósiles de dinosaurios. La comunidad autónoma de Aragón posee un gran número de yacimientos icnológicos, concretamente 19. Algunos de ellos, como es el caso del yacimiento de Ababuj, han quedado relegados y corren el riesgo de sufrir una pérdida irreparable si no se realizan las adecuadas labores de rehabilitación y conservación. El yacimiento de Ababuj cuenta con 25 huellas de dinosaurio, de las cuales 20 corresponden a saurópodos y 5 a terópodos. Está formado por dos niveles datados en el Jurásico Superior, con un espesor de 40 a 50 cm. entre los mismos, lo que indica que no son niveles isócronos. Además, existen huellas con datación similar en Barkhausen (Alemania), Los Cayos (La Rioja, España) y Morrison (EEUU). Este yacimiento ha sido catalogado como Bien de Interés Cultural en el 2003, sin embargo, este trabajo pretende poner en valor la necesidad de continuar realizando nuevos estudios. Asimismo, se propone llevar a cabo un proceso de musealización con el consiguiente "Plan Director", elaborando un anteproyecto junto a la Fundación Dinópolis para estudiar la viabilidad de la propuesta. De ser ésta positiva, se instauraría una ruta a lo largo de toda la provincia de Teruel, que conectaría los distintos yacimientos que hasta la fecha se conocen.

\section{EXCAVACIÓN DE UN BONE-BED DE LA FORMACIÓN MORRISON (JURÁSICO SUPERIOR), SAN- JUAN COUNTY, UTAH}

\section{J. KALUZA ${ }^{1}$}

${ }^{1}$ Fundación de Historia Natural "Félix de Azara", Centro de Estudios Biomédicos, Biotecnológicos, Ambientales y Diagnóstico (CEBBAD)Universidad Maimónides. Hidalgo 775, C1405CBK Ciudad Autónoma de Buenos Aires, Argentina. yojonatan@hotmail.com

La Formación Morrison es una unidad rocosa del Jurásico Superior (155-148 Ma) que se extiende por todo el oeste de los Estados Unidos y es portadora de una gran diversidad faunística que ha sido estudiada por más de un siglo. Esta formación se caracteriza por depósitos de canales fluviales portadores de huesos de gran porte como dinosaurios, depósitos de lago y estanques de agua que presentan un mayor potencial de preservación de fósiles de menor tamaño, como esqueletos de ranas, lagartos y mamíferos. Antiguos canales fluviales de meandros han preservado en paquetes de areniscas intercaladas, en ocasiones con arcillas, huesos que han sido enterrados rápidamente y forman una asociación multiespecífica de esqueletos articulados. El yacimiento denominado Gnatalie Quarry (estado de Utah, Área de Four Corners de la meseta de Colorado) ha producido en los últimos 10 años de exploración una abundante diversidad de fósiles colectados en alrededor de 405 bochones. El trabajo de extracción de dinosaurios de mediano y gran tamaño preservados en distintos planos de disposición en un bone-bed presenta grandes dificultades al momento de planear y realizar una excavación sistemática tradicional. Este trabajo intenta exponer las diversas estrategias utilizadas a lo largo de una década en la dinámica de trabajo y colecta de estos materiales. La utilización de maquinaria vial en la apertura de un quarry, las distintas técnicas de extracción combinadas entre sí, la elaboración de un mapa y las técnicas de fotogrametría son algunas de los procedimientos utilizados en la extracción.

\section{CONSERVACIÓN PREVENTIVA EN LA COLECCIÓN DE VERTEBRADOS FÓSILES DE LA UNIVERSIDAD NACIONAL DEL NORDESTE, ARGENTINA}

\section{C.A. Luna ${ }^{1}$, M.C. Prieto², A.R. Miño-Bollinin', V.E. Espindola ${ }^{1}$ y A.E. Zurita ${ }^{1}$}

${ }^{1}$ Centro de Ecología Aplicada del Litoral (CECOAL)-Consejo Nacional de Investigaciones Científicas y Tecnológicas (CONICET)-Universidad Nacional del Nordeste. Ruta 5, km 2,5, 3400 Corrientes, Argentina.carlosaluna@hotmail.com

${ }^{2}$ Instituto Multidisciplinario de Biología Vegetal (IMBIV)-Consejo Nacional de Investigaciones Científicas y Tecnológicas (CONICET). Av. Vélez Sarsfield 1666, X5016GCN Córdoba, Argentina.

La Colección Paleontológica de la Universidad Nacional del Nordeste Dr. Rafael Herbst es una de las más importantes del 
país, albergando una notable colección de vertebrados fósiles (CTES-PZ) de Argentina y del exterior desde hace más de 35 años, e incluyendo varios holotipos. En el marco de un plan de manejo se ha realizado un relevamiento preliminar del estado de conservación y condiciones ambientales del repositorio (Oct-Dic 2017). Durante las jornadas laborales se registraron temperaturas cuyas medias fueron $\mathrm{T}_{\min } 24,6^{\circ} \mathrm{C}, \mathrm{T}_{\max } 29,5^{\circ} \mathrm{C}$ y DT media $3,9^{\circ} \mathrm{C}$ con valores extremos de $\mathrm{T}_{\min } 20^{\circ} \mathrm{C}, \mathrm{T}_{\max }$ $34,4^{\circ} \mathrm{C}$ y DT $7,6^{\circ} \mathrm{C}$. En tanto la humedad relativa (HR) presentó medias de $\mathrm{HR}_{\min } 51,4 \%$ y $\mathrm{HR}_{\max } 67,9 \%$ con $\mathrm{DHR}_{\text {media }} 12,4 \%$, registrándose como valores extremos $\mathrm{HR}_{\min } 36 \%, \mathrm{HR}_{\max } 84 \%$ y DHR $25 \%$. La media para los valores máximos de ambos parámetros se encuentra por encima de los estándares internacionales de conservación. A pesar de ello, la mayor parte de los ejemplares se preservan en buen estado, aunque algunos evidencian procesos de deterioro atribuidos principalmente a variaciones en el grado de humedad (fracturación o escamación en superficie, alteración en materiales con altos contenidos de $\mathrm{Fe}_{2} \mathrm{O}_{3}$, alteración de productos utilizados durante tratamientos de consolidación). El reconocimiento de esta situación ha determinado la necesidad de almacenar los materiales con alto grado de deterioro en contenedores plásticos con soportes internos de espuma de polipropileno con el objeto de disminuir las variaciones de T y HR, establecer condiciones químicas neutras y proveer un adecuado soporte para los mismos.

\title{
PROTECCIÓN Y CONSERVACIÓN DE FÓSILES POR PARTE DEL MUSEO ARGENTINO URQUIZA, RINCÓN DE LOS SAUCES, NEUQUÉN
}

\section{S. PALOMO ${ }^{1}$}

1Museo Municipal "Argentino Urquiza". Jujuy y Chaco s/n, Q8319BFA Rincón de los Sauces, Neuquén, Patagonia Argentina. spalomoneuquen@gmail.com

Con el objeto de adoptar medidas tendientes a la protección y conservación del patrimonio paleontológico de la zona próxima a Rincón de los Sauces (Neuquén), el MAU realiza periódicos relevamientos, los cuales consisten en detectar y rescatar materiales expuestos que podrían ser destruidos por eventos climáticos, como así también por movimientos de suelo realizados por trabajos relacionados con la actividad hidrocarburífera. En este sentido, en el año 2012, se realizó un acuerdo con la empresa Exxon móvil, con el objeto de llevar adelante una prospección en el área de "La Invernada" dando como resultado la detección de distintos materiales fósiles de relevancia, los cuales fueron extraídos en posteriores campañas. Uno de estos hallazgos correspondió a un ejemplar de titanosaurio, el cual se encontraba en muy buen estado de preservación y articulado desde el cráneo hasta la cadera. Este ejemplar ha sido extraído durante el año 2015, y posteriormente preparado en el laboratorio del museo. Si bien, los restos craneanos de estos dinosaurios han sido hallados en distintas latitudes, en el mundo se cuenta con muy pocos cráneos completos y bien preservados como el de este ejemplar, el cual actualmente se encuentra bajo estudio.

\section{RE DISEÑANDO LAS SALAS DEL MUSEO DE CIENCIAS ANTROPOLÓGICAS Y NATURALES DE LA UNIVERSIDAD NACIONAL DE LA RIOJA CON CRITERIOS MUSEOLÓGICOS Y PALEOARTE}

\author{
S.E. PÉrEZ PARRY ${ }^{1}$
}

${ }^{1}$ Museo de Ciencias Antropológicas y Naturales, Universidad Nacional de La Rioja. Av. Luis M. de la Fuente s/n, Ciudad Universitaria de la Ciencia y de la Técnica, F5300 La Rioja, Argentina. sebastianperezparry@gmail.com

El actual edificio del Museo de Ciencias Antropológicas y Naturales de la Universidad Nacional de La Rioja data del año 2001 y presenta dos grandes salas, una de paleontología y otra de arqueología. En los últimos 4 años se ha comenzado con una reestructuración de las mismas incorporando obras de paleoarte exhibidas con criterios museológicos. En el marco de estas disciplinas se ha adecuado la información al público infantil, principal segmento que asiste al museo, a pesar de pertenecer el mismo al ámbito universitario. Además, se han realizado esculturas símil vida que recrean la fauna extinta y se ha adecuado el guión museográfico para facilitar un recorrido cronológico. El espacio ha sido optimizado además para crear una sala de muestras temporarias y un rincón infantil donde se realizan talleres de paleoarte durante las vacaciones de invierno. El recorrido está conformado por módulos interactivos que permiten acceder a la información brindada desde la experiencia. En este contexto las modificaciones se planifican mediante estudios de público con el objeto de optimizar la experiencia. Para generar una continuidad y coherencia en los cambios paulatinos que se fueron suscitando, se ha realizado un proyecto integral con el objeto de continuar con la remodelación de las salas en distintas etapas según los presupuestos solicitados. 


\title{
PRESENTACIÓN DEL PARQUE PLEISTOCÉNICO DE LA REGIÓN DE ANSENUZA, PROVINCIA DE CÓRDOBA
}

\author{
S.E. Pérez Parry ${ }^{1}$, C.A. Ferreyra² y M.A. Meza ${ }^{3 *}$ \\ ${ }^{1}$ Museo de Ciencias Antropológicas y Naturales, Universidad Nacional de La Rioja. Av. Luis M. de la Fuente s/n, Ciudad Universitaria de la Ciencia \\ y de la Técnica, F5300 La Rioja, Argentina. sebastianperezparry@gmail.com \\ ${ }^{2}$ Museo Histórico Municipal "La Para". Gral. Julio A. Roca 551 (Ex Estación Ferroviaria), X5137ANQ La Para, Córdoba, Argentina. \\ kandyferreyra@gmail.com \\ 3Parque Geológico Sanagasta. Ruta 75 km 32, 5301 Sanagasta, La Rioja, Argentina.mezamariadelosangeles@gmail.com \\ En el año 2015 surgió el proyecto para la creación de la muestra "Grandes Bestias de Ansenuza" entre la dirección del \\ Museo Histórico Municipal de La Para (Córdoba), a cargo del Mg. Carlos Ferreyra, y los museólogos Sebastián Pérez Parry \\ y Ángeles Meza. El objetivo de la misma fue el de presentar la megafauna del Pleistoceno en la sala de muestras tempo- \\ rarias del museo parense. A tal efecto, se presentaron 5 reconstrucciones paleoartísticas que representaban las cabezas \\ de las especies más conocidas de este periodo. La realización de esta muestra sirvió para presentar en la comunidad la ne- \\ cesidad de ampliar el conocimiento sobre la prehistoria de la región de la Laguna Mar Chiquita y permitió poner en marcha \\ la creación de un parque temático que contará con 9 reconstrucciones completas y en escala real de Megatherium cuvier, \\ Stegomastodon platensis, Doedicurus clavicaudatus y Smilodon populator, entre otros. Para su planificación se tuvieron en \\ cuenta diversos criterios museológicos tales como: cercado perimetral, portal con control del ingreso, oficina técnica y del \\ personal, laguna artificial con islas, cartelería indicativa exterior e interior, senderos y áreas de descanso y área para la con- \\ tención de grupos de alumnos y contingentes turísticos. En cuanto a su ubicación se utilizó un predio cercano al museo, den- \\ tro del cuadro de estación del Ferrocarril. La creación de este parque temático, pronto a inaugurar, permitirá el acceso al co- \\ nocimiento de la paleontología del Cuaternario de la región de Ansenuza.
}

*Proyecto subsidiado por el Municipio de La Para y ASETUR.

\section{OBTENCIÓN DE POSITIVOS TRIDIMENSIONALES A PARTIR DE MOLDES NATURALES}

\author{
S. REUIL ${ }^{1}$ Y P. MUZZOPAPPA 2,3
}

'Sección Paleontología de Vertebrados, Museo Argentino de Ciencias Naturales "Bernardino Rivadavia". Av. Ángel Gallardo 470, C1405DJR Ciudad Autónoma de Buenos Aires, Argentina. santiagoreuil@gmail.com

${ }^{2}$ Fundación de Historia Natural "Félix de Azara", Universidad Maimónides. Hidalgo 775, C1405CBK Ciudad Autónoma de Buenos Aires, Argentina.pmuzzopappa@fundacionazara.org.ar; pmuzzopappa@gmail.com

${ }^{3}$ Consejo Nacional de Investigaciones Científicas y Técnicas (CONICET).

El estudio de restos fósiles preservados en forma de molde natural requiere de técnicas particulares. Aún en casos en que la preservación es muy buena, el estar en forma de impronta dificulta la observación anatómica. Para el estudio de estos fósiles frecuentemente se realizan copias flexibles (positivo) aplicando caucho de silicona sobre el molde natural (negativo). Esta copia positiva permite además observar estructuras que se extiendan lateralmente en el sedimento por debajo de la línea de corte, ocultas a la observación directa. No obstante, en la mayoría de los casos esto significa la obtención de positivos parciales e independientes (cara y contracara). A su vez, la línea de corte en el molde natural es aleatoria, lo que significa que el contorno de cada elemento en el positivo estará definido no solo por su anatomía sino también por la forma en la que se haya partido la laja. Trabajando con fósiles del anuro Calyptocephalella (Strand, 1928) nos encontramos frecuentemente con estas problemáticas y con la intención de lograr positivos que permitan una mejor apreciación de su anatomía, desarrollamos la técnica que aquí presentamos. La clave de esta técnica consiste en la correcta alineación inicial de las partes, el uso de encastres confeccionados a medida que permitan una correcta alineación en pasos sucesivos y la obtención de positivos intermedios. En el paso final, se obtiene un positivo compuesto, tridimensional, en material rígido (resina) y libre de sedimento para su estudio. 